\title{
Treating Bacterial Infections with Bacteriophage-Based Enzybiotics: In Vitro, In Vivo and Clinical Application
}

\author{
Katarzyna M. Danis-Wlodarczyk ${ }^{1, *}$, Daniel J. Wozniak ${ }^{1,2}$ and Stephen T. Abedon ${ }^{2}$ (D) \\ 1 Department of Microbial Infection and Immunity, The Ohio State University, Columbus, OH 43210, USA; \\ wozniak.1@osu.edu \\ 2 Department of Microbiology, The Ohio State University, Columbus, OH 43210, USA; abedon.1@osu.edu \\ * Correspondence: danis-wlodarczyk.1@osu.edu
}

check for updates

Citation: Danis-Wlodarczyk, K.M.; Wozniak, D.J.; Abedon, S.T. Treating Bacterial Infections with

Bacteriophage-Based Enzybiotics: In Vitro, In Vivo and Clinical

Application. Antibiotics 2021, 10, 1497. https://doi.org/10.3390/

antibiotics 10121497

Academic Editor: Sanna

Maria Sillankorva

Received: 23 October 2021

Accepted: 29 November 2021

Published: 6 December 2021

Publisher's Note: MDPI stays neutral with regard to jurisdictional claims in published maps and institutional affiliations.

Copyright: (c) 2021 by the authors. Licensee MDPI, Basel, Switzerland. This article is an open access article distributed under the terms and conditions of the Creative Commons Attribution (CC BY) license (https:/ / creativecommons.org/licenses/by/ $4.0 /)$.

\begin{abstract}
Over the past few decades, we have witnessed a surge around the world in the emergence of antibiotic-resistant bacteria. This global health threat arose mainly due to the overuse and misuse of antibiotics as well as a relative lack of new drug classes in development pipelines. Innovative antibacterial therapeutics and strategies are, therefore, in grave need. For the last twenty years, antimicrobial enzymes encoded by bacteriophages, viruses that can lyse and kill bacteria, have gained tremendous interest. There are two classes of these phage-derived enzymes, referred to also as enzybiotics: peptidoglycan hydrolases (lysins), which degrade the bacterial peptidoglycan layer, and polysaccharide depolymerases, which target extracellular or surface polysaccharides, i.e., bacterial capsules, slime layers, biofilm matrix, or lipopolysaccharides. Their features include distinctive modes of action, high efficiency, pathogen specificity, diversity in structure and activity, low possibility of bacterial resistance development, and no observed cross-resistance with currently used antibiotics. Additionally, and unlike antibiotics, enzybiotics can target metabolically inactive persister cells. These phage-derived enzymes have been tested in various animal models to combat both Gram-positive and Gram-negative bacteria, and in recent years peptidoglycan hydrolases have entered clinical trials. Here, we review the testing and clinical use of these enzymes.
\end{abstract}

Keywords: endolysin; EPS depolymerase; lysin; phage therapy; Pseudomonas aeruginosa; Staphylococcus aureus; tail spike protein; virion-associated peptidoglycan hydrolase

\section{Introduction}

During WWII, penicillin was widely distributed to soldiers [1-3], resulting in the observation of the first "naturally" resistant Staphylococcus strains only 16 years (1944) after its discovery as the first antibiotic [4]. By 1948, up to 59\% of the Staphylococcus isolates in hospital settings were penicillin-resistant [5,6]. Even though many new classes of antibiotics have been introduced since that time, their over prescription and misuse has resulted in today's global antibiotic-resistance crisis [7,8]. Antibiotics are still very much part of standard-of-care treatments, however, and save many people from life-threatening bacterial infections. The year 1987 nevertheless marks the introduction of the last new class of antibiotics, lipopeptides $[9,10]$, and for over 30 years no new antibiotics classes have been introduced to the market [7]. As we continue to experience a surge in bacterial antibiotic resistance, including pan- and multi-drug-resistant strains, there is a need for new antibacterials, especially ones with novel mechanisms of action.

Enzybiotics are just such a promising alternative to standard antibiotics, possessing novel mechanisms of anti-pathogen action. The term 'enzybiotics' is a portmanteau word combining 'enzyme' and 'antibiotic'. It was first used by Nelson et al. [11] in 2001 to refer to endolysins, often described simply as 'lysins', which are peptidoglycan hydrolases (PGHs) produced by bacteriophages or phages, bacterial viruses that can lyse and kill bacteria [12,13]. Especially in recombinant, purified forms, these lysins can be used as extracellularly acting antibacterial agents [14-17]. More recently, the term 'enzybiotics' has 
been used to describe not just lysins but also polysaccharide depolymerases (PSDs) [18], which are phage-derived enzymes that can also be used extracellularly to degrade bacterial polysaccharides, such as biofilm matrix, capsules, slime layers, or lipopolysaccharide (LPS). See Figure 1 for a summary of additional usage of this enzybiotic concept.

Here, we review the phage-encoded enzybiotics, PGHs and PSDs, which, to date, have been developed only from phages belonging to the Caudovirales order. We provide overviews of their in vitro properties, results of animal studies, and, for PGHs, clinical trials and human cases studies.

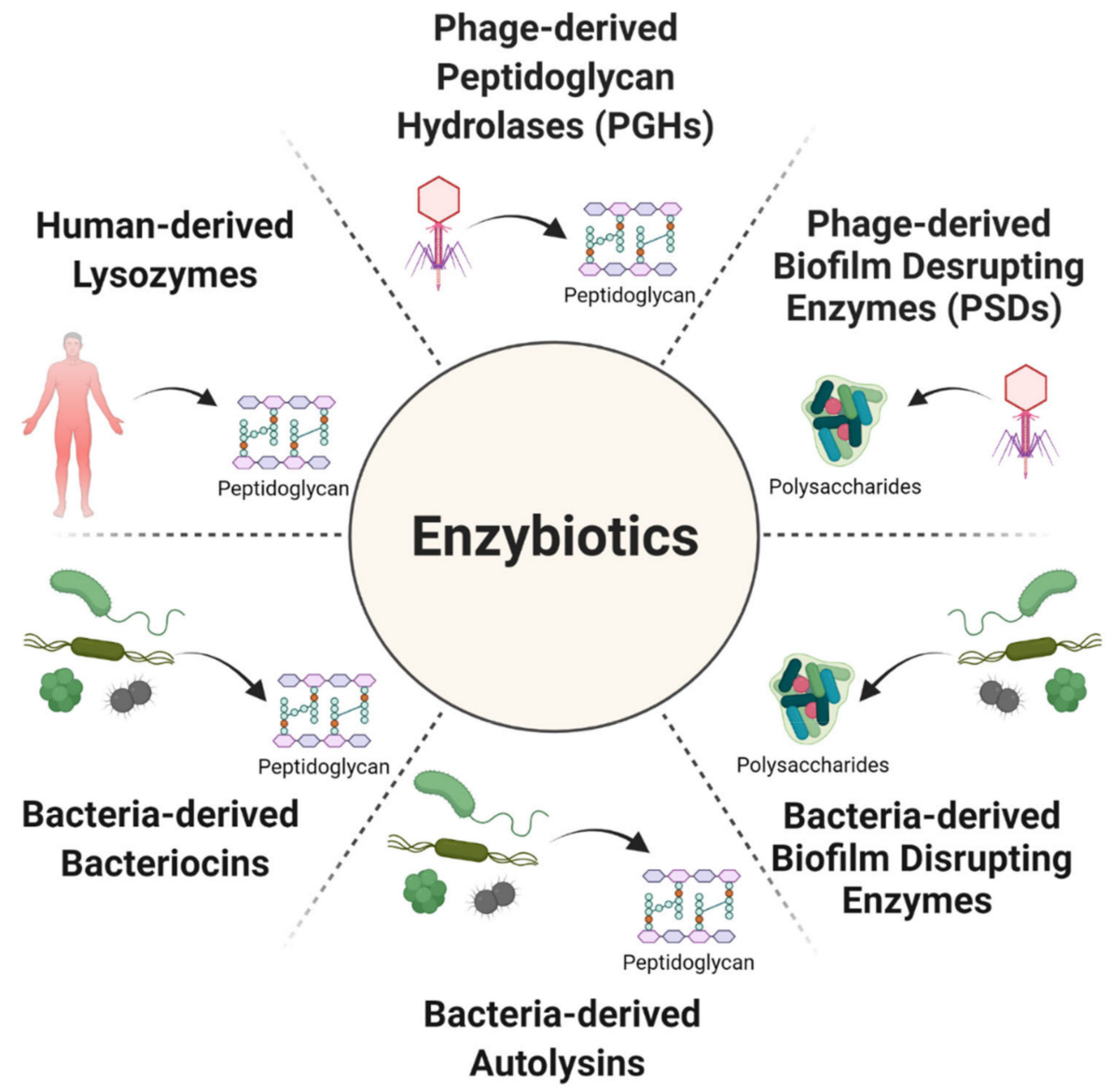

Figure 1. There are six main categories of enzybiotics. These include phage-derived enzymes: (1) peptidoglycan hydrolases (PGHs, which include endolysins and virion-associated peptidoglycan hydrolases) and (2) biofilm-disrupting enzymes (polysaccharide depolymerases, PSDs). In addition, among enzybiotics there are bacteria-derived enzymes: (3) biofilm-disrupting enzymes [19,20], (4) autolysins [21-24], which are bacterial enzymes that break down peptidoglycan to enable the separation of daughter cells following cell division, and (5) bacteriocins [24-28], which are bacteria-produced antibacterial proteins or peptides that inhibit the growth of closely related bacteria. Moreover, among enzybiotics are animal-derived enzymes including (6) the lysozymes found in natural body fluids, e.g., tears, saliva, milk, and mucous $[24,27,29]$. In addition, although not shown, there are enzybiotics with antifungal activities, i.e., fungal endoglucanases [30]. Arrows connect enzybiotic sources with targeted substrates. Figure created with BioRender.com (2020).

\section{Phage Enzymes as the Basis of New Antibacterial Therapies}

For over 100 years, whole phages have been successfully applied to treat various bacterial infections [31-47]. This includes infections caused by pathogens belonging to infamous ESKAPE group (Enterococcus faecium, Staphylococcus aureus, Klebsiella pneumoniae, Acinetobacter baumannii, Pseudomonas aeruginosa, and Enterobacter spp.) [48], whose members literally have escaped from currently available antibacterial therapies [49]. Many countries 
nevertheless are still cautious in their use of phages for human therapy due to challenges in pharmaceutical production, uncontrollable dosing, immunogenicity, possibility of horizontal gene transfer (particularly if temperate phages are used for therapy), resistance occurrence, legislative hurdles, and intellectual property issues [50-53]. Therefore, approximately 20 years ago, researchers started to explore phage-encoded antibacterial enzymes that can overcome some of these phage-therapy limitations. A comparison of the typical attributes of antibiotics, phages, PSDs, and PGHs [18,24,27,30,53-69] is found in Figure 2. Importantly, manufacturing PSDs and PGHs should not pose many hurdles since large scale recombinant protein production and purification strategies are well established.

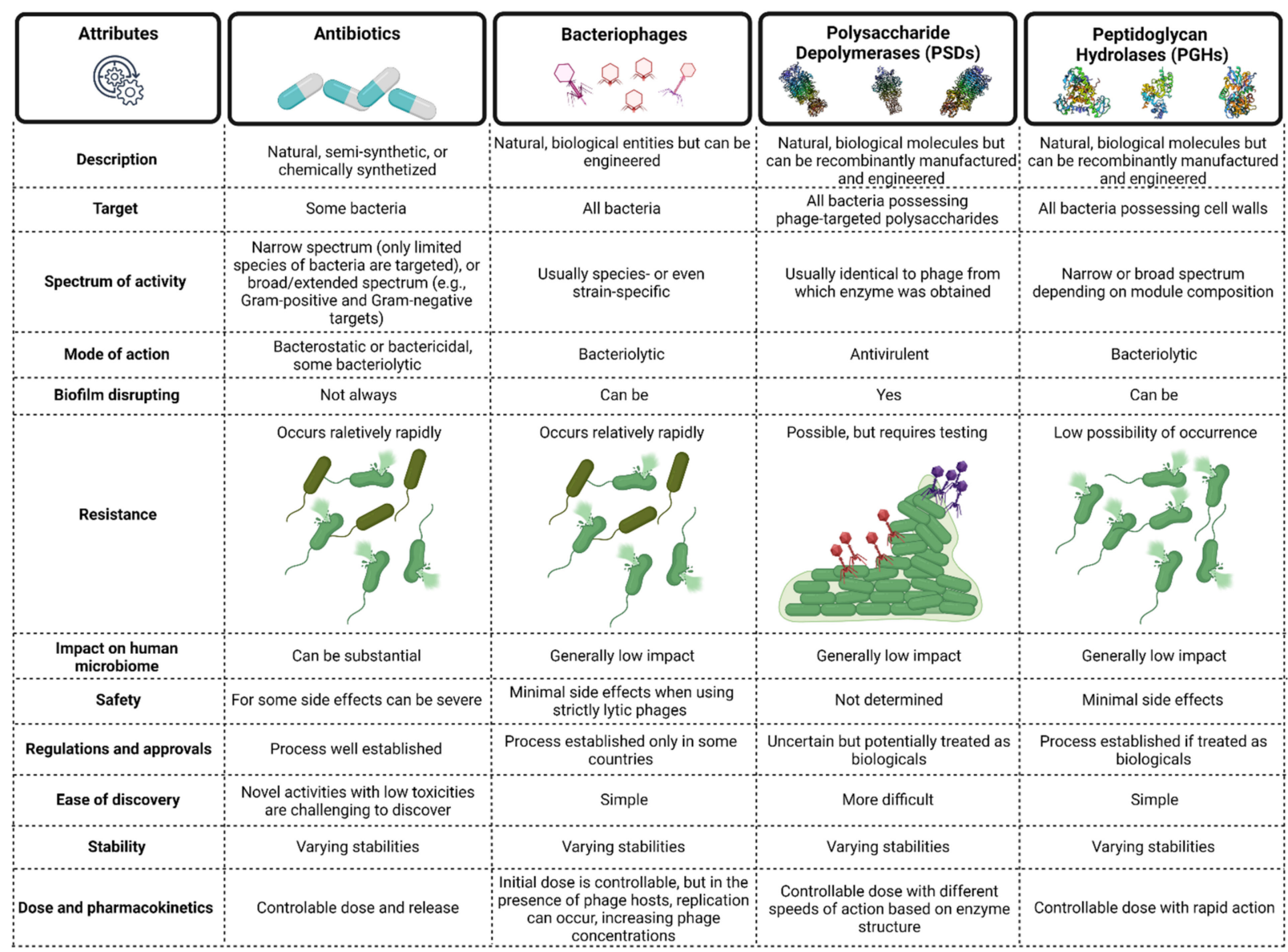

Figure 2. Typical attributes of antibiotics, bacteriophages, and two classes of phage enzymes, polysaccharide depolymerases (PSDs) and peptidoglycan hydrolases (PGHs). Figure created with BioRender.com (2020).

\section{Roles of Polysaccharide Depolymerases and Lysins during Phage Infection Cycles}

PGHs and PSDs play crucial roles during tailed-phage infections (Figure 3). First, PSDs [18,56-58,70-72] allow phages to degrade the bacterial barriers consisting of capsular polysaccharides (CPS), exopolysaccharides (EPS), and lipopolysaccharides (LPSs) [18], permitting virions to reach the compatible adsorption receptors found on cell-envelope surfaces [73-75]. Subsequently, the phage tail apparatus mechanically penetrates the bacterial cell wall, with the assistance of virion-associated peptidoglycan hydrolases (VAPGHs) that belong to the PGH group $[15,64,76]$. VAPGHs degrade the peptidoglycan layer only locally, generally without bacterial cell lysis [64], as at this step the phage needs to maintain the stability of the bacterial cell to continue its infection process [64]. In a pure, recombinantly manufactured form, VAPGHs, however, can lyse and kill bacteria upon direct contact with the cell walls [61], causing a variation in what is described in the phage literature as a lysis from without [76]. 


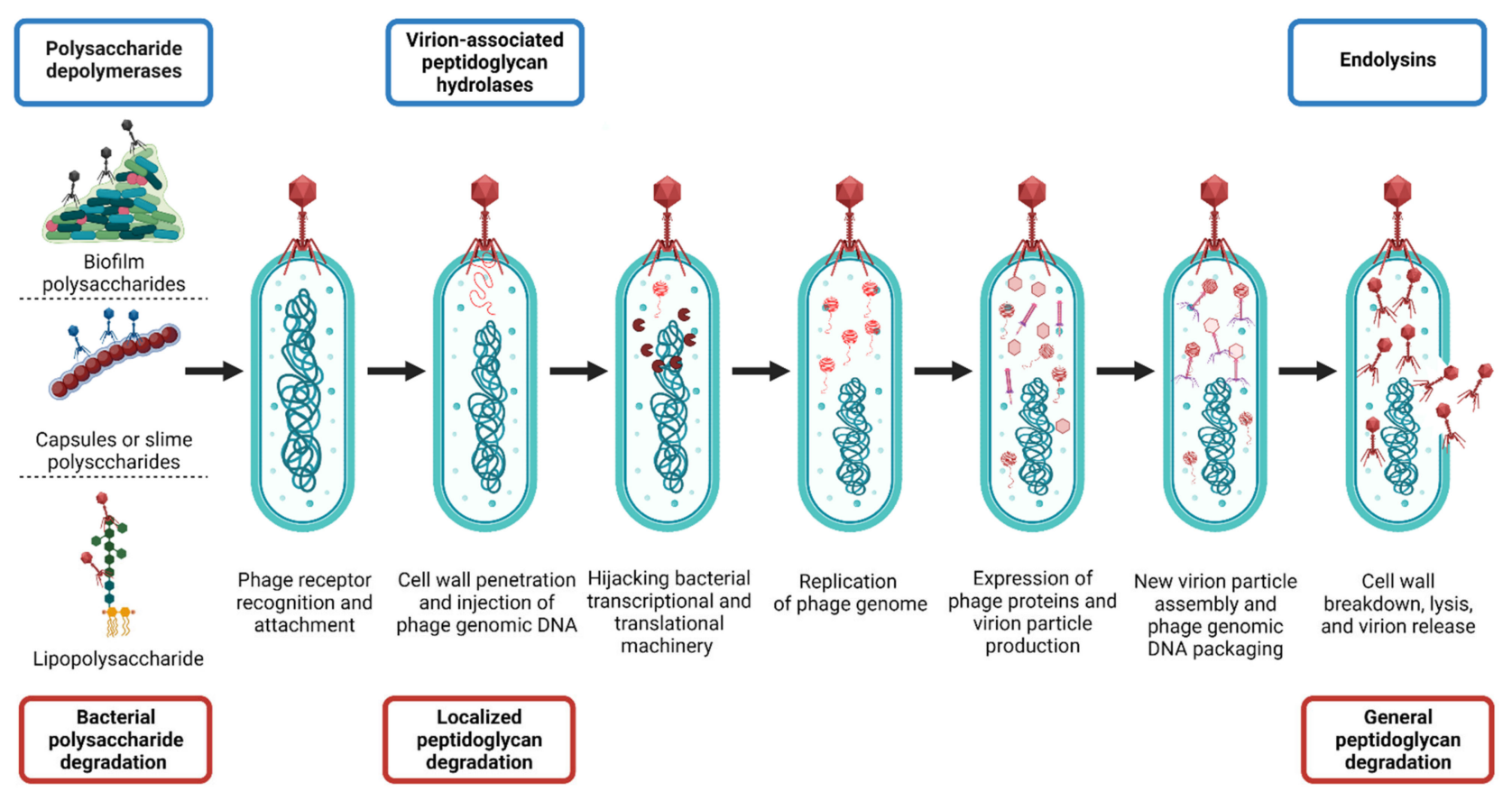

Figure 3. Lytic infection cycle of Caudovirales phages and involvement of phage-encoded enzymes, PSDs and PGHs, which in purified forms can possess extracellular antibacterial properties. Phage-encoded enzybiotics are listed in blue boxes on top and their activity is described in red boxes at the bottom. Figure created with BioRender.com (2020).

Next, phage genomic material is translocated into the bacterial cytoplasm, with bacterial transcriptional and translational machinery then hijacked by phage gene products in order to replicate phage genomes and assemble new virion particles. For dsDNA phages, holin proteins then perforate the bacterial inner membrane [77,78], allowing endolysins, the other type of PGHs, to gain access to the peptidoglycan layer and break down its structure. In the case of Gram-negative bacteria, phages also produce spanins that function to breach the bacterial outer membrane [79]. The result is a global degradation of the bacterial cell wall $[76,80-83]$ and the release of new virion particles into the extracellular milieu. PSDs may also be used at this step to prevent the entrapment of newly released virions within biofilms [84].

\section{Phage-Encoded Polysaccharide Depolymerases (PSDs)}

As follows, we consider PSD enzymatic activities, discovery, in vitro properties, and in vivo testing.

\subsection{PSD Substrate Diversity}

PSDs collectively have a broad diversity in terms of their substrate specificities [18], although they can be generally differentiated into two classes: hydrolases and lyases [85] (Figure 4). The hydrolases catalyze the hydrolysis of glycosidic bonds [58] and currently include six groups: sialidases (hydrolyzing $\alpha-2,8-$ linkages in capsular polysialic acid) [86], rhamnosidases (cleaving $\alpha-1,3 \mathrm{O}$-glycosidic bonds between L-rhamnose and D-galactose) [87], levanases (hydrolyzing $\beta$-2,6-bonds between fructose monomers in levan) [88,89], xylanases (cutting $\beta-1,4$ bonds within xylan) [90-93], dextranases (cleaving $\alpha-1,6$-linkages between glucose units in dextran) [94,95], and LPS deacetylases (deacetylating the O-antigen) $[55,66,96]$. The lyases instead cleave $(1,4)$ glycosidic bonds by a $\beta$-elimination mechanism $[97,98]$ and currently comprise five groups: hyaluronate lyase (cleaving $\beta-1,4$ bonds in hyaluronic acid) [99], pectate lyase (cleaving $\alpha-1,4$ bonds of polygalacturonic acid) [100,101], alginate lyase (cutting $\alpha-1,4$ bonds of alginate) [102,103], K5 lyase (cleaving $\alpha-1,4$ bonds of $E$. coli $\mathrm{K} 5$ capsules) [104], and O-specific polysaccharide lyase (cleaving of O-specific antigen of LPS) [105]. 


\subsection{Plaque Halo Zones}

PSDs are often virion-associated as parts of tail fibers, tail spikes, baseplates, or neck proteins (Figure 4). They can also be released as free enzymes upon phage-induced lysis from within $[18,58,106]$. The latter occurs due either to the production by phage infections of excess proteins that do not end up being incorporated into virions, or the use of alternative start codons in their translation that result in the production of both soluble and virion-associated forms $[18,58]$. Both of these unincorporated forms can freely diffuse, causing polysaccharide degradation that is physically separated from PSD-producing phage infections [100,107], resulting in phage plaque-surrounding halo zones [75,100,105,106,108]. These halos may increase in size over a prolonged incubation time as free PSDs diffuse further within agar into bacterial lawns, although in some cases they can be absent, e.g., in the case of the Salmonella phage PVP-SE1 $[58,109]$. It is via the presence of these halo zones around phage plaques that PSDs are typically identified phenotypically.
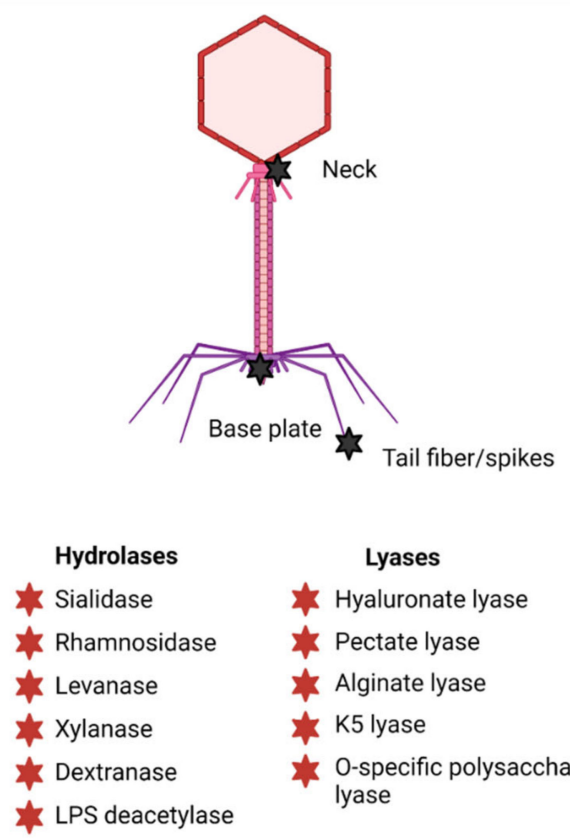
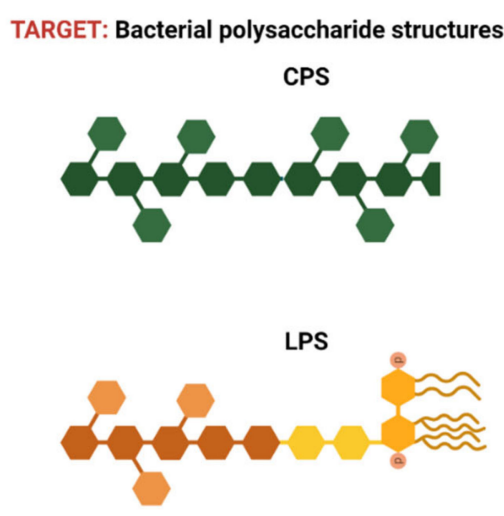

EPS
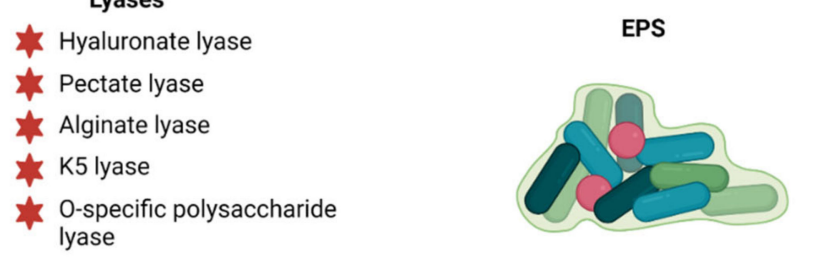

Figure 4. Phage-encoded polysaccharide depolymerases. PSDs virion-association is illustrated with black stars (upper, left), different enzyme classes are marked with red stars (lower, left), and bacterial polysaccharide targets are shown on the right. Abbreviations: (CPS) capsular polysaccharides, (LPS) lipopolysaccharides, (EPS) exopolysaccharides. Figure created with BioRender.com (2020).

\subsection{Roadblocks to PSD-Gene Identification}

Because of their diversity, an important bottleneck in PSD research and development is identification of their genes within phage genomes. In general, for many phage genes, putative functions cannot be assigned due to the limited homology to genes with known functions that are available in current databases. These genes, often described as ORFans [110-112], represent approximately $30 \%$ of the sequenced phage genomes [113], something that has been described as viral 'dark matter'. In order to assign functions to these genes, there is often a need for experimental validation, e.g., [112], a process that can be laborious. The result is a low diversity of PSD genes that are available in databases and, therefore, limitations of new PSD gene discovery. Several groups, however, have attempted to bioinformatically identify PSD genes and their active domains $[18,58]$ or construct protein prediction software, prediction models, or datasets, e.g., [114,115]. Nevertheless, it seems that the diversity of PSDs in nature may be much broader than what is currently known and available in databases. 


\subsection{Additional PSD Properties}

Phages and their enzymes are part of the natural human microbiome [116-118] and serve as natural modulators of bacterial communities. They are generally considered to be safe and non-toxic [55,119]. PSDs also present high substrate specificity, leaving commensal flora unharmed. Bacterial resistance may evolve, however, due to modifications of bacterial polysaccharides, especially LPS or capsules. These modifications often lead to LPS or capsule defects that can result in lower bacterial fitness or virulence, e.g., [120-123].

In a handful of studies, anti-polysaccharide enzymes have also been used in purified $[27,84,91,92,103,105,124-135]$ or phage-associated forms $[127,136,137]$ towards the enhancement of antibacterial or anti-biofilm activities in vitro [122,136,138]. Phages can also be engineered with additional or new polysaccharide depolymerase genes that can be utilized during treatment, e.g., of bacterial biofilms [137]. Furthermore, phage depolymerases may act as antibiotic adjuvants, diagnostic tools, e.g., for targeting or detecting bacterial serotypes $[66,84,105]$ or toward the production of oligosaccharides derived from polysaccharides $[139,140]$.

Formulation possibilities can range from liquids to dry powders, ether of which can be stored for long periods [141-143]. Phage enzymes also tend to remain stable at wide $\mathrm{pH}$ ranges $[55,105,144]$ as well as at both $4{ }^{\circ} \mathrm{C}$ and $-80^{\circ} \mathrm{C}$.

\subsection{In Vivo Charateristics}

As antimicrobials, PSDs can be applied exogenously to degrade bacterial polysaccharides or potentially resensitize bacteria to antibiotics or the immune system $[58,66]$, including to serum killing as well as phagocytosis. To our knowledge, however, the in vivo analyses of phage depolymerase efficacy have been limited to animal testing (Table 1). The published studies, however, present high animal survival rates when pretreated or treated with phage-derived recombinant and purified polysaccharide depolymerases, with no toxicity observed. PSDs in addition have been found to reduce bacterial virulence and levels of proinflammatory cytokines [145]. Like many other non-endogenous therapeutic proteins, i.e., biologics, PSDs might still induce allergic responses, although these have not been reported [146-148]. Phage-derived PSDs, therefore, represent a promising category of innovative antimicrobials to combat biofilms, reduce bacterial virulence, and improve immune-mediated killing [18,58,71,72,84,100,105,149]. 
Table 1. Phage-derived polysaccharide depolymerases efficacy in vivo.

\begin{tabular}{|c|c|c|c|c|c|c|c|}
\hline Enzyme & Pathogen & Animal & Infection & Inoculum & Dosing & Results & Ref. \\
\hline $\begin{array}{l}\text { P22 tailspike } \\
\text { protein } \\
\text { (P22sTsp) } \\
\text { recognizing } \\
\text { LPS }\end{array}$ & $\begin{array}{l}\text { Salmonella } \\
\text { enterica serovar } \\
\text { Typhimurium }\end{array}$ & Leghorn chicks & $\begin{array}{l}\text { Intestinal } \\
\text { colonization }\end{array}$ & $\begin{array}{l}\text { Oral gavaging, } \\
300 \mathrm{~L} \text { PBS containing } \\
10^{4} \text { to } 10^{7} \mathrm{CFU}\end{array}$ & $\begin{array}{l}\text { Oral gavaging, } 300 \mu \mathrm{L} \text { in } 10 \% \text { BSA containing } 30 \\
\mathrm{mg} ; 3 \text { doses: } 1 \text { st } 1 \mathrm{~h} \text { post-infection, } 2 \text { nd and } 3 \mathrm{rd} \\
\text { dose given in } 24 \mathrm{~h} \text { intervals }\end{array}$ & $\begin{array}{l}\text { 100-fold reduction of Salmonella colonization in the gut as well as reduced } \\
\text { liver and spleen penetration; Salmonella motility was impaired }\end{array}$ & [150] \\
\hline $\begin{array}{l}\text { Dep-ORF8 } \\
\text { targeting } \\
\text { capsular } \\
\text { serogroup A }\end{array}$ & $\begin{array}{l}\text { Pasteurella } \\
\text { multocida } \\
\text { capsular } \\
\text { serogroup A }\end{array}$ & $\begin{array}{l}\mathrm{BALB} / \mathrm{c} \text { mouse } \\
\text { model }\end{array}$ & $\begin{array}{l}\text { Systemic } \\
\text { infection }\end{array}$ & $\begin{array}{l}\text { IP injection of } 100 \mu \mathrm{L} \\
\text { containing } 80 \mathrm{CFU}\end{array}$ & $\begin{array}{l}3 \text { treatment groups: IP injection } \\
\text { of } 100 \mu \mathrm{L} \text { containing } 36 \mu \mathrm{g} \text { at } 6 \mathrm{~h} \text { (group 1), } 12 \mathrm{~h} \\
\text { post-infection (group 2), and } 12 \mathrm{~h} \text { post-infection, } \\
\text { and then once daily for } 5 \text { days (group } 3 \text { ) }\end{array}$ & $\begin{array}{c}\text { Treatment: group } 1 \text { showed } \sim 70 \% \text {, and } 50 \% \text { survival within } 3 \text { and } 5 \text { days, } \\
\text { respectively; group } 2 \text { showed } 70 \%, 50 \% \text {, and } \sim 35 \% \text { survival within } 3,5 \text {, } \\
\text { and } \\
12 \text { days, respectively; group } 3 \text { showed } \sim 80 \%, 70 \% \text { survival within } 4 \text { and } 6 \\
\text { days, respectively; } \\
\text { control group } 100 \% \text { mortality within } \\
5 \text { days }\end{array}$ & [151] \\
\hline $\begin{array}{l}\text { gp49, } \\
\text { O-specific } \\
\text { polysacharide } \\
\text { lyase }\end{array}$ & $\begin{array}{l}\text { Pseudomonas } \\
\text { aeruginosa }\end{array}$ & $\begin{array}{l}\text { Galleria } \\
\text { mellonella } \\
\text { (Wax moth } \\
\text { larvae) }\end{array}$ & $\begin{array}{l}\text { Hemocoel } \\
\text { infection }\end{array}$ & $\begin{array}{l}\text { Injection into the last } \\
\text { pro-leg of } 10 \mathrm{CFU}\end{array}$ & $\begin{array}{l}\text { Pretreatment: } 1 \mathrm{~h} \text { incubation } \\
\text { of bacteria with } 50 \mu \mathrm{g} / \mathrm{mL} \text {; treatment: } 5 \text { or } 50 \\
\mu \mathrm{g} / \mathrm{mL} \text { was injected } 15 \mathrm{~min} \text { post-infection }\end{array}$ & $\begin{array}{c}\text { Pretreatment: } 24 \mathrm{~h} \text { post injection, } 50 \% \\
\text { of larvae survived ( } 30 \% \text { more than } \\
\text { in the control); } 35 \% \text { larvae also survived to the end of the experiment }(>72 \\
\text { h); } \\
\text { treatment: } 24 \mathrm{~h} \text { post-treatment, } \\
\text { the larvae survival rate was at least } 20 \% \text { higher compared to the control, } \\
\text { independent of gp } 49 \text { concentration; } 20 \% \text { of larvae survived up to } 72 \mathrm{~h} \\
\text { with treatment, while } 100 \% \text { of control group died } 48 \mathrm{~h} \text { post injection }\end{array}$ & [105] \\
\hline $\begin{array}{l}\text { depoKP36 } \\
\text { targeting KP } 36 \\
\text { capsule }\end{array}$ & $\begin{array}{l}\text { Klebsiella } \\
\text { pneumoniae }\end{array}$ & $\begin{array}{l}\text { G. mellonella } \\
\text { (Wax moth } \\
\text { larvae) }\end{array}$ & $\begin{array}{l}\text { Hemocoel } \\
\text { infection }\end{array}$ & $\begin{array}{l}\text { Injection into the last } \\
\text { pro-leg of } 10 \mu \mathrm{L} \text { containing } \\
110^{7} \mathrm{CFU}\end{array}$ & $\begin{array}{c}\text { Pretreatment: bacteria were pretreated with } \\
\text { depoKP36 } \\
\begin{array}{c}(280 \mu \mathrm{g} / \mathrm{mL}) \text { for } 2 \mathrm{~h} \text { before infection; treatment: } \\
\text { depoKP36 } \\
\text { was administered } 5 \text { min post-infection }\end{array}\end{array}$ & $\begin{array}{l}\text { Pretreatment: } 77 \% \text { of larvae were saved within } 24 \mathrm{~h} \text {, and } 47 \% \text { and } 43 \% \\
\text { after } 48 \mathrm{~h} \text { and } 72 \mathrm{~h} \text {, respectively; } \\
\text { treatment: survival increased up to } 40 \%, 30 \% \text {, and } 20 \% \text { after } 24 \mathrm{~h}, 48 \mathrm{~h} \text {, } \\
\text { and } 72 \mathrm{~h} \text { post-treatment, respectively; } \\
100 \% \text { of untreated larvae died }\end{array}$ & [132] \\
\hline $\begin{array}{l}\text { Dp42 targeting } \\
\text { capsular } \\
\text { polysaccharide } \\
\text { type KN1 }\end{array}$ & К. pneumoniae & $\begin{array}{l}\mathrm{BALB} / \mathrm{c} \text { mouse } \\
\text { model }\end{array}$ & $\begin{array}{l}\text { Systemic } \\
\text { infection }\end{array}$ & $\begin{array}{l}\text { IP injection } \\
\text { of } 2 \times 10^{7} \mathrm{CFU}\end{array}$ & $\begin{array}{l}\text { Prevention: IP injection of } 200 \mu \mathrm{L} \text { containing } 0.25 \\
\mathrm{mg} / \mathrm{mL} 6 \mathrm{~h} \text { before bacterial infection; } \\
\text { pretreatment: } 0.25 \mathrm{mg} / \mathrm{mL} \text { for } 30 \text { min; treatment: } \\
\text { IP injection of } 200 \mathrm{~mL} \text { containing } \sim 50 \mathrm{mg} 30 \mathrm{~min} \\
\text { post-infection }\end{array}$ & $\begin{array}{c}\text { Prevention: } 100 \% \text { survival within } 96 \mathrm{~h} \text { post-infection, while } 100 \% \text { of } \\
\text { control group died within } 9 \mathrm{~h} ; \\
\text { pretreatment: } 1 \text { mouse died }(12.5 \%) \\
54 \mathrm{~h} \text { post-infection, while } 100 \% \\
\text { of control group died within } 12 \mathrm{~h} \text {; } \\
\text { treatment: identical to pretreatment results. }\end{array}$ & [152] \\
\hline $\begin{array}{l}\text { K64dep } \\
\text { targeting K64 } \\
\text { capsular type } \\
\text { polysaccharides }\end{array}$ & К. рпеитопіае & $\begin{array}{l}\text { BALB/cByl } \\
\text { mouse model } \\
\text { CP treated, } \\
200 \mathrm{mg} / \mathrm{kg} \text { IP } \\
\text { injections } \\
\text { in } 2 \text { days } \\
\text { intervals }\end{array}$ & $\begin{array}{l}\text { Systemic } \\
\text { infection }\end{array}$ & $\begin{array}{l}\text { IP injection } \\
\text { of } 6 \times 10^{6} \mathrm{CFU}\end{array}$ & $\begin{array}{l}\text { IP injection with } 150 \mu \mathrm{g}, 37.5 \mu \mathrm{g} \text {, } \\
\text { or } 18.75 \mu \mathrm{g} \text { at } 1 \mathrm{~h}, 8 \mathrm{~h} \text {, and } 24 \mathrm{~h} \text { post-infection }\end{array}$ & $\begin{array}{l}\text { 100\% survival with } 18.75 \mu \mathrm{g} \text { dose applied } 1 \mathrm{~h} \text { post-infection; in control } \\
\text { group, } 100 \% \text { mortality was observed; } 150 \mu \mathrm{\mu g} \text { dose applied } 8 \mathrm{~h} \\
\text { post-infection had no effect; } \\
\text { no K64dep-related toxicity was observed as well as no changes in liver, } \\
\text { kidney, and spleen histopathology; } \\
\text { treatment sensitizes carbapenem-resistant K64 to serum killing in vitro } \\
\text { as well as increased its susceptibility } \\
\text { to neutrophil killing }(\sim 40 \% \text { improved killing) }\end{array}$ & [153] \\
\hline $\begin{array}{l}\text { Endosialidase } \\
\text { E } \\
\text { (endoE) }\end{array}$ & $\begin{array}{l}\text { Escherichia coli } \\
\text { producing K1 } \\
\quad \text { antigen }\end{array}$ & Neonatal rats & $\begin{array}{l}\text { Intestinal } \\
\text { colonization } \\
\text { and } E \text {. } \\
\text { coli-related } \\
\text { bacteremia }\end{array}$ & $\begin{array}{l}\text { Oral administration of } 20 \\
\mu \mathrm{L} \text { containing } \\
2 \text { to } 6 \times 10^{6} \mathrm{CFU}\end{array}$ & $\begin{array}{l}\text { IP injection of } 20 \mu \mathrm{g} \text { on days } \\
1,2,3,4, \text { and } 5 \text { post-infection }\end{array}$ & $\begin{array}{l}\text { No direct effect on } E \text {. coli viability but pathogen is sensitized to } \\
\text { complement system killing; } \\
\text { single dose on day } 1 \text { of endoE prevents the death of infected pups and } E \text {. } \\
\text { coli invasion of the bloodstream; } \\
80-100 \% \text { survival in comparison } \\
\text { to } 0-10 \% \text { survival in untreated control }\end{array}$ & [133] \\
\hline
\end{tabular}


Table 1. Cont.

\begin{tabular}{|c|c|c|c|c|c|c|c|}
\hline Enzyme & Pathogen & Animal & Infection & Inoculum & Dosing & Results & Ref. \\
\hline $\begin{array}{l}\text { Endosialidase } \\
\text { E } \\
\text { (endoE) }\end{array}$ & $\begin{array}{l}\text { E. coli } \\
\text { producing K1 } \\
\text { antigen }\end{array}$ & Neonatal rats & $\begin{array}{l}\text { Intestinal } \\
\text { colonization } \\
\text { and } E \text {. } \\
\text { coli-related } \\
\text { bacteremia }\end{array}$ & $\begin{array}{l}\text { Oral administration of } 20 \\
\mu \mathrm{L} \text { containing } \\
2 \text { to } 6 \times 10^{6} \mathrm{CFU}\end{array}$ & $\begin{array}{l}\text { IP injection of } 0.125-20 \mu \mathrm{g} \text { range } \\
\text { on days } 1 \text { post-infection }\end{array}$ & $\begin{array}{l}\text { Minimal dose of } 0.25 \mu \mathrm{g} \text { prevented death of at least } 80 \% \text { of rats; } \\
\text { treatment sensitizes } E \text {. coli to serum killing in vitro, and improved } \\
\text { macrophage ingestion of } E \text {. coli }\end{array}$ & [134] \\
\hline $\begin{array}{l}\text { Dep6, } \\
\text { O91-specific } \\
\text { polysaccharide } \\
\text { depolymerase }\end{array}$ & $\begin{array}{l}\text { Shiga toxin- } \\
\text { producing } E \text {. } \\
\text { coli }\end{array}$ & $\begin{array}{l}\text { BALB } / \mathrm{c} \text { mouse } \\
\text { thigh model }\end{array}$ & $\begin{array}{l}\text { Systemic } \\
\text { infection }\end{array}$ & $\begin{array}{l}\text { Injection near the right } \\
\text { thigh of } 100 \mu \mathrm{L} \text { containing } \\
2.4 \times 10^{8} \mathrm{CFU}\end{array}$ & $\begin{array}{c}\text { Dose: } 100 \mu \mathrm{L} \text { containing } 0.3 \mu \mathrm{g} / \mu \mathrm{L} ; \\
\text { toxicity: IP injection; prophylactic: delivery } 3 \mathrm{~h} \\
\text { prior to infection; } \\
\text { simultaneous treatment: delivery } \\
\text { at the same time as bacterial inoculum; } \\
\text { delayed treatment: delivery } 3 \mathrm{~h} \text { post-infection }\end{array}$ & $\begin{array}{c}\text { Toxicity analysis: no pathological changes in liver, kidney, or small } \\
\text { intestine observed; } \\
\text { pretreatment: } 100 \% \text { survival; } \\
\text { simultaneous treatment: } 83 \% \text { survival; } \\
\text { delayed treatment: } 33 \% \text { survival; } \\
\text { significant reduction in the levels }\end{array}$ & [138] \\
\hline $\begin{array}{l}\text { Capsule } \\
\text { depolymerases } \\
\text { active against } \\
\text { three } \\
\text { different } \\
\text { capsule types: } \\
\text { K1, K5, and } \\
\text { K30 }\end{array}$ & E. coli & $\begin{array}{l}\text { NIH Swiss } \\
\text { Mouse thigh } \\
\text { model }\end{array}$ & $\begin{array}{l}\text { Systemic } \\
\text { infection }\end{array}$ & $\begin{array}{l}\text { Injection into thigh of } 100 \\
\mu \mathrm{L} \text { containing } 1 \text { to } 4 \times 10^{8} \\
\qquad \mathrm{CFU}\end{array}$ & $\begin{array}{l}\text { Injection of } 100 \mu \mathrm{L} \text { PBS containing } 0,2,5 \text {, or } 20 \mu \mathrm{g} \\
\text { doses, } 30 \text { min post-infection; different } \\
\text { depolymerases tested }\end{array}$ & $\begin{array}{c}\text { Toxicity: no toxicity observed; } \\
\text { treatment: control group did not survive, whereas most mice were } \\
\text { rescued by treatment with } 20 \mu \mathrm{g} \text { dose per mouse; } \\
\text { effective doses of K1F and K1H enzymes were between } 2 \mu \mathrm{g} \text { (both } \\
\text { partially rescuing) and } 5 \mu \mathrm{g} \text { (both rescuing } 100 \% \text { mice) per mouse; for K5, } \\
\text { the effective dose was between } 2 \text { and } 20 \mu \mathrm{g} \text { per mouse; K30 gp41 rescued } \\
\text { mice at the higher dose tested ( } 20 \mu \mathrm{g} \text { per mouse); } \\
\text { a mixture of K30 gp } 41 \text { and K30 gp42 yielded the same survival outcome } \\
\text { as K30 gp41 alone }\end{array}$ & [122] \\
\hline $\begin{array}{c}\text { \$AB6 } \\
\text { targeting } \\
\text { capsular } \\
\text { polysaccharide }\end{array}$ & $\begin{array}{l}\text { Acinetobacter } \\
\text { baumannii }\end{array}$ & Zebrafish & $\begin{array}{l}\text { Systemic } \\
\text { infection }\end{array}$ & $\begin{array}{l}\text { Injection through cloaca of } \\
1 \text { to } 4 \times 10^{7} \mathrm{CFU}\end{array}$ & $\begin{array}{l}\text { Injection through cloaca of } 20 \mu \mathrm{L} \text { protein }(1 \\
\mu \mathrm{g} / \mu \mathrm{L}), 30 \text { min post-infection }\end{array}$ & $\begin{array}{l}\text { Treatment: survival rate was significantly improved ( } 80 \%) \text { compared with } \\
\text { untreated control }(10 \%) ; \\
\text { toxicity: none observed }\end{array}$ & [154] \\
\hline $\begin{array}{l}\text { Dpo48 } \\
\text { capsule } \\
\text { depolymerase }\end{array}$ & A. baumannii & $\begin{array}{l}\text { G. mellonella } \\
\text { (Wax moth } \\
\text { larvae) }\end{array}$ & $\begin{array}{l}\text { Hemocoel } \\
\text { infection }\end{array}$ & $\begin{array}{l}\text { Injected into the last } \\
\text { pro-leg of } 10 \mu \mathrm{L} \text { PBS } \\
\text { containing } 10^{6} \mathrm{CFU}\end{array}$ & $\begin{array}{c}\text { Pretreatment: } 50 \mu \mathrm{g} / \mathrm{mL} \text { for } 1 \mathrm{~h} \text {; treatment: } \\
\text { Injection of } 10 \mu \mathrm{L} \text { PBS containing } 5 \mu \mathrm{g} 5 \mathrm{~min} \\
\text { post-infection }\end{array}$ & $\begin{array}{c}\text { Pretreatment: } 100 \% \text { survival, while, } \\
\text { in control group } \sim 65 \% \text { and } 84 \% \\
\text { of larvae died within } 24 \mathrm{~h} \text { and } 72 \mathrm{~h} \text {, respectively; } \\
\text { treatment: } 76 \% \text { survival, while, in control group, } 65 \% \text { and } 84 \% \text { of larvae } \\
\text { died within } 24 \mathrm{~h} \text { and } 72 \mathrm{~h} \text {, respectively }\end{array}$ & \multirow{3}{*}{ [155] } \\
\hline \multirow[b]{2}{*}{$\begin{array}{l}\text { Dpo48 } \\
\text { capsule } \\
\text { depolymerase }\end{array}$} & \multirow[b]{2}{*}{ A. baumannii } & $\begin{array}{l}\mathrm{BALB} / \mathrm{c} \text { mice } \\
\text { model }\end{array}$ & $\begin{array}{l}\text { Systemic } \\
\text { infection }\end{array}$ & $\begin{array}{l}\text { IP injection } \\
\text { of } 10^{7} \mathrm{CFU}\end{array}$ & $\begin{array}{c}\text { IP injection of } 200 \mu \mathrm{L} \text { PBS containing } 50 \mu \mathrm{g} 2 \mathrm{~h} \\
\text { post-infection }\end{array}$ & $\begin{array}{l}100 \% \text { mice treated survived and appeared healthy for } 7 \text { days, while } 100 \% \\
\text { of the untreated control died within } 24 \mathrm{~h} \text { due to peritoneal sepsis; } \\
\text { bacterial count in tissue and organs was significantly reduced with } \\
\text { treatment } 6 \mathrm{~h} \text { post-infection in comparison to control group }\end{array}$ & \\
\hline & & $\begin{array}{l}\mathrm{BALB} / \mathrm{c} \text { mice } \\
\text { model, IP } \\
\text { injection of CP } \\
(300 \mathrm{mg} / \mathrm{kg}) \\
\text { in } 200 \mu \mathrm{L} \text { PBS, } \\
3 \text { days before } \\
\text { infection }\end{array}$ & $\begin{array}{l}\text { Systemic } \\
\text { infection }\end{array}$ & $\begin{array}{l}\text { IP injection } \\
\text { of } 10^{7} \mathrm{CFU}\end{array}$ & $\begin{array}{l}\text { IP injection of } 200 \mu \mathrm{L} \text { of PBS containing } 50 \mu \mathrm{g} 2 \mathrm{~h} \\
\text { post- infection }\end{array}$ & $\begin{array}{l}100 \% \text { of mice treated survived and appeared healthy for } 7 \text { days, while } \\
100 \% \text { of untreated control died within } 24 \mathrm{~h} \text { due to peritoneal sepsis }\end{array}$ & \\
\hline
\end{tabular}


Table 1. Cont.

\begin{tabular}{|c|c|c|c|c|c|c|c|}
\hline Enzyme & Pathogen & Animal & Infection & Inoculum & Dosing & Results & Ref. \\
\hline \multirow[t]{2}{*}{$\begin{array}{l}\text { K2 capsular } \\
\text { depolymerase }\end{array}$} & \multirow[t]{2}{*}{$\begin{array}{l}\text { A. baumannii } \\
\text { capsular type } \\
\quad \mathrm{K} 2\end{array}$} & $\begin{array}{l}\text { G. mellonella } \\
\text { (Wax moth } \\
\text { larvae) }\end{array}$ & $\begin{array}{c}\text { Hemocoel } \\
\text { infection }\end{array}$ & $\begin{array}{l}\text { Injection into the last } \\
\text { pro-leg of } 5.5 \mu \mathrm{L} \text { of } 20 \mathrm{mM} \\
\text { HEPES containing } 10^{6} \mathrm{CFU}\end{array}$ & $\begin{array}{l}\text { Pretreatment: bacteria pretreated with protein for } \\
2 \mathrm{~h} \text {; treatment: injection of enzyme } 30 \mathrm{~min} \\
\text { post-infection; in both scenarios, a range of protein } \\
\text { dosages were used }(0.25 \mathrm{~g}, 0.5 \mathrm{~g} \text {, and } 3 \mathrm{~g} / \text { larvae })\end{array}$ & $\begin{array}{c}\text { No toxicity, } 100 \% \text { survival of larvae; } \\
\text { pretreatment: untreated control group survival rate was } 25 \%, 20 \% \text {, and } \\
10 \% \text { after } 24,48 \text {, and } 72 \mathrm{~h} \text {, respectively; in group with pretreatment after } \\
72 \mathrm{~h}, 53 \%, 69 \% \text {, and } 88 \% \text { of larvae survived using } 0.25 \mathrm{~g}, 0.5 \mathrm{~g} \text {, and } 3 \mathrm{~g} \\
\text { pretreatments; } \\
\text { treatment: only } 35 \%, 22 \% \text {, and }<15 \% \text { larvae survived in untreated control } \\
\text { after } 24 \mathrm{~h}, 48 \mathrm{~h}, 72 \mathrm{~h} \text {, respectively, while } 73 \%, 40-76 \%, 56-70 \% \text { survived } \\
\text { with treatment; K2 depolymerase is highly refractory to resistance } \\
\text { development }\end{array}$ & \multirow[t]{2}{*}{ [156] } \\
\hline & & $\begin{array}{l}\text { BALB } / \mathrm{c} \text { mouse } \\
\text { model, IP } \\
\text { injection of } \mathrm{CP} \\
(100 \mathrm{mg} / \mathrm{kg}) \\
4 \text { and } 1 \text { day } \\
\text { before infection }\end{array}$ & $\begin{array}{l}\text { Systemic } \\
\text { infection }\end{array}$ & $\begin{array}{l}\text { IP injection } \\
\text { of } 10^{7} \mathrm{CFU}\end{array}$ & IP injection with $50 \mu \mathrm{g}$ dose $1 \mathrm{~h}$ post-infection & $\begin{array}{l}20 \mathrm{~h} \text { post-infection control group had } \\
\text { to be euthanized, while in a treatment group } 90 \% \text { mice had survived, } \\
\text { decreasing to } 60 \% \text { at } 42 \mathrm{~h} \text { post-infection }\end{array}$ & \\
\hline
\end{tabular}




\section{Phage-Encoded Peptidoglycan Hydrolases (PGHs)}

PGHs can be divided into two groups, ectolysins and endolysins [157]. Ectolysins ('ecto' referring to 'outside'), also known as VAPGHs $[15,64]$, are used by phages at the beginning of infection cycles to locally degrade bacterial peptidoglycan and allow the virus to inject its genome (Figure 3). Endolysins, in contrast, are responsible for the cell wall destruction that takes place during the phage-mediated lysis from within-'endo' meaning 'within' - that occurs at the end of the phage lytic infection cycle (Figure 3).

\subsection{Basic Characteristics}

PGHs have become extensively studied for 20 years, e.g., [11,15,17,53,54,59,61,63$65,67,69,82,106,141-144,148,157-230]$. They can be easily identified and prepared as pure recombinant proteins and have proven to be efficient in killing bacteria, including multidrug-resistant variants [231-234]. They are rapid-acting [166,202,235-239] and stable over a range of $\mathrm{pHs}$ and temperatures $[182,240,241]$. PGHs also selectively target specific species of bacteria without harming commensal microflora [61,242,243]. Examples of pathogens against which they have been developed include Bacillus anthracis [180], Clostridium spp. [178,244], Enterococcus faecium [183], P. aeruginosa [205], S. aureus [186], S. epidermidis [188,245], S. pneumoniae [185], K. pneumoniae [184], and many others [27]. They can be used to treat biofilms [164,188,205,246-250], can be applied to mucosal surfaces [251], and are active against persister cells $[188,252,253]$. Furthermore, PGHs can serve as cotreatments with other antibacterial therapies, e.g., antibiotics or antibacterial enzymes of different origins [82,146,168,192,198,254-262].

In the course of in vivo studies (Section 5), PGHs have been found to display low toxicities $[148,157,212,225,263-272]$. Nevertheless, due to their proteinaceous nature, they may induce allergic reactions. PGHs can be applied not only in medicine [273] but also in the food industry $[172,174,202,213,242,274-280]$, during biofuel production [210,281], in agriculture [282-284], and in veterinary medicine [258,285-293]. As with PSDs, they are suitable for a range of formulations and can be delivered via different routes, such as topical (creams, ointments, and gels), injections (intravenous or intraperitoneal), orally, transnasally, or vaginally $[55,157,158]$.

\subsection{Spectra of Activities and Resistance Evolution}

The probability of bacterial resistance occurrence to PGHs is generally assumed to be low $[142,157,190,198,212,222,252,253,273,294,295]$. Some documentation exists of resistance to engineered forms or other types of PGHs, however, such as to human lysozyme [296-299] and Staphylococcus simulans secreted lysostaphin [300,301]. Resistance may occur due to, e.g., (1) modifications of peptidoglycan- and/or cell-wall-linked components, such as Dalanylation of teichoic acids, O-acetylation and N-deacetylation of peptidoglycan [298,299,302]; (2) mutations allowing the formation of monoglycine cross-bridges, which eliminate the target site for the bacteriocins' catalytic site [273]; or (3) protection by small immunity proteins that bind to and inactivate the enzymes (pesticin secreted by Yersinia pestis cells [303]). The extracellular mode of action of PGHs, however, hampers the majority of the known intracellular antimicrobial resistance mechanisms, such as reduced membrane permeability, efflux pumps, and inactivation by cytoplasmic enzymes.

In comparison to whole phages (Figure 2), PGHs usually have a broader specificity [69], although not so broad as to disrupt normal microflora. This is because they target only a single bacterial macromolecule (peptidoglycan), which has a composition that is usually somewhat conserved at the species level versus the reliance by whole phages on multiple bacterial macromolecules for successful infection [69]. On the other hand, and unlike PSDs, unmodified PGHs usually have difficulty reaching their substrate targets in Gram-negative bacteria, as the cell walls there are surrounded by outer membranes [304], which serve as efficient barriers to protein diffusion [191,194,253,305]. For this reason, different approaches have been undertaken in recent years to support lysin activity against Gram-negative pathogens, including the use of chemical or physical methods to 
destabilize their outer membranes (e.g., high hydrostatic pressure, EDTA [217,306], citric acid, malic acid [216], carvacrol [307], cationic dendronized silver nanoparticles [308]) or synthetic biology and protein engineering to fuse outer membrane permeabilizing peptides with lysins (e.g., Artilysins ${ }^{\circledR}$ ) [304]. Additionally, this approach allows to broaden the PGHs' activity range, modify their specificity, as well as alter their other properties [53,61,62,67,191,194,203,215,252,253,303,305,309-311].

In recent years, also several lysin were discovered that have a natural capacity to penetrate the Gram-negative outer membrane. This property is called an intrinsic antibacterial activity [304]. Some of these enzymes possess unusually broad activity spectra, spanning from Gram-negative to Gram-positive pathogens [304,312-315]. Their mechanism of action is not fully understood, but it is hypothesized that it is correlated with a self-promoted uptake mechanism by a C-terminal amphipathic helix that interacts with the outer membrane, while the $N$-terminal enzymatic domain degrades peptidoglycan [304]. It is possible that this C-terminal amphipathic helix acts similarly to phage spanin in spanin-less phages, disrupting the bacterial outer membrane from within $[79,304]$. The uptake can be further enhanced by a positively charged hexaHis-tag [312,313,316].

\subsection{Structure and Mode of Action of Phage-Derived Peptidoglycan Hydrolases}

Although they have a conserved biological function, i.e., the degradation of bacterial cell wall material, PGHs nonetheless are diverse in their structures, catalytic activity, specificity, and enzyme kinetics [62,317]. This is due in part to differences between the Gram-negative and Gram-positive bacterial cell wall structure. Enzymes targeting Gramnegative bacteria usually have a globular structure consisting of an enzymatically active domain (EAD) [203], while enzymes targeting Gram-positive bacteria have a modular structure composed of an $N$-terminal EAD, flexible interdomain linker region, and Cterminal cell-wall-binding domain (CBD) [54,158,170,171,318,319]. Exceptions, however, exist, such as the presence of two EADs. Additionally, mycobacteriophages produce two forms of EAD lysins, lysin A (peptidoglycan hydrolase) and lysin B (mycolyl arbinoglacan esterase) [69,320,321].

CBDs are responsible for the noncovalent binding to different epitopes on bacterial cell wall surfaces, such as teichoic acids, peptides, or carbohydrates, facilitating the enzymatic activity of EADs [54,171,177,322,323]. Like PSDs, the EADs of PGHs also have different catalytic activities, targeting different bonds in the peptidoglycan structure (Figure 5C). They are divided into three distinctive classes: glycosidases, amidases, and endopeptidases. Glycosidases cleave $\beta-1,4$ glycosidic bonds linking $N$-acetylmuramic acids (MurNAc) and $N$-acetylglucosamines (GlcNAc) in the peptidoglycan structure and include (1) $N$ acetyl- $\beta$-D-muramidases (similar to lysozyme) that cleave the $N$-acetylmuramoyl- $\beta-1,4-$ $N$-acetylglucosamine bond, one of the two alternating glycosidic bonds of the glycan strand, and (2) N-acetyl- $\beta$-D-glucosaminidases that hydrolyze the other glycosidic bond ( $N$-acetylglucosaminyl- $\beta-1,4-N$-acetylmuramine), which is found between the peptidoglycan sugars. Amidases, i.e., $\mathrm{N}$-acetylmuramoyl-L-alanine amidases, cleave amide bonds between sugar (glycan, MurNac) and L-alanine, the first amino acid in the side peptide stem. Endopeptidases cleave between amino acids in the side stem peptide. These include L-alanoyl-D-glutamate endopeptidases (VANY), c-D-glutamyl-m-diaminopimelic (DAP) acid peptidase, D-Ala-m-DAP endopeptidase, and D-alanyl-glycyl endopeptidase (CHAP), etc. $[170,171,207,323,324]$.

There are different models for the export of phage endolysins during infection cycles. These generally are divided into two groups: holin-dependent and holin-independent, the latter as found in association with what are described as pin-hole holins. For further discussion, see, e.g., [14]. In Figure 5, we represent only the holin-dependent mechanism. 


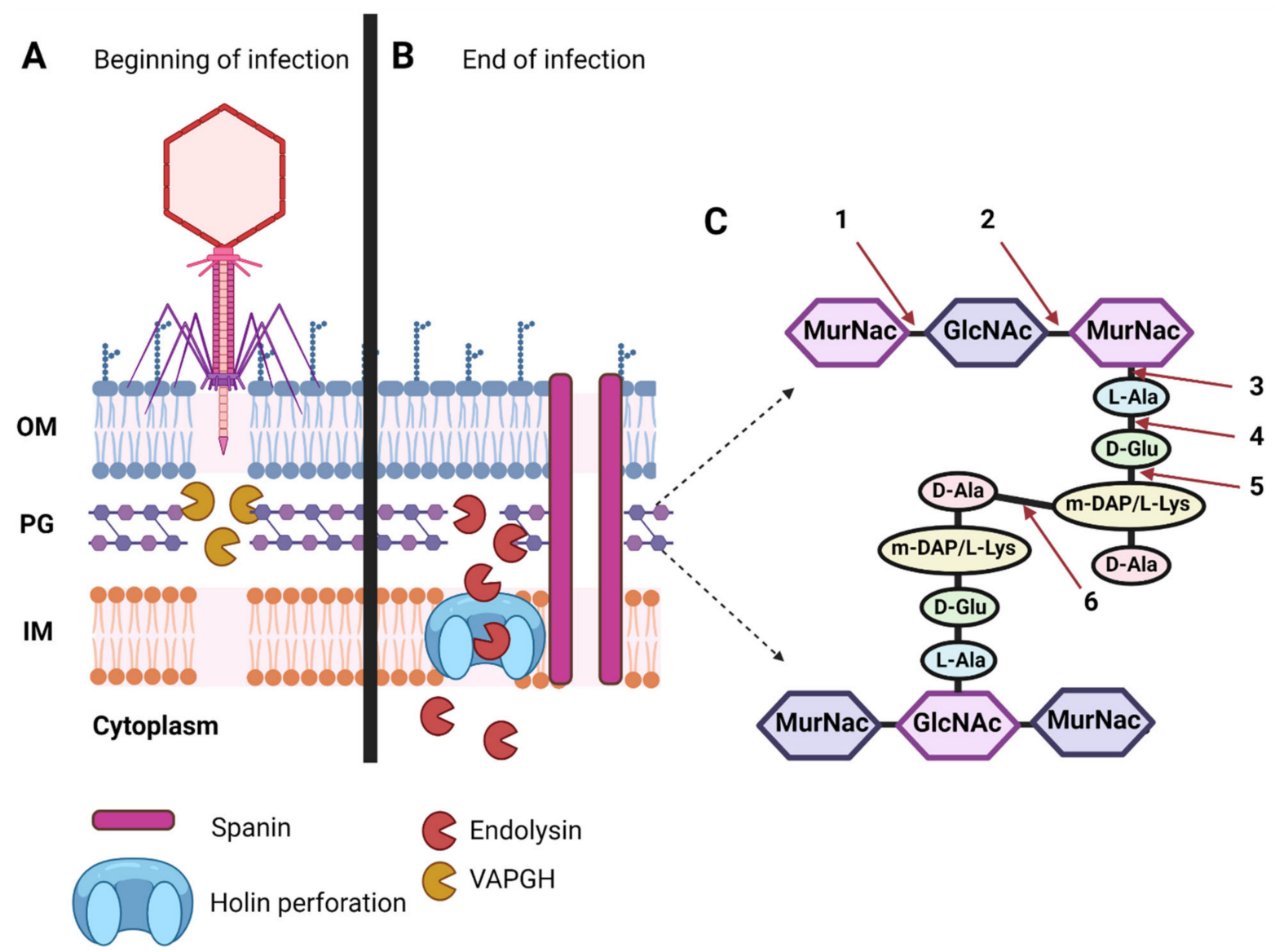

Figure 5. Mode of action of the peptidoglycan-degrading enzymes. (A) Schematic representation of Gram-negative bacteria cell wall structure. OM represents bacterial outer membrane, which is absent in the case of Gram-positive bacteria. PG is the peptidoglycan layer and IM stands for inner membrane. At the beginning of phage infection cycles, phage virions mechanically perforate bacterial cell walls with their tail structures. This process may be assisted by virion-associated peptidoglycan hydrolases that digest through bacterial PG. (B) At the end of phage infection cycles, with holin-dependent translocation mechanisms, holins are distributed in the IM, creating 2D aggregates called "rafts", which lead to a collapse in the proton motive force and lesion (blue doughnut) formation (perforation of the inner membrane). Endolysins (red packman symbols) can then pass to access the peptidoglycan layer. Additionally, another set of proteins called spanins (pink bars spanning from IM to OM) is required to disrupt the outer membrane in the lysis of Gram-negative bacteria. Finally, bacterial cell wall lysis occurs. (C) Bacterial peptidoglycan structure magnification. The PG layer is built with alternating $N$-acetylmuramic acids (MurNAc) and $N$-acetylglucosamines (GlcNAc), which are crosslinked by peptide stems. The interpeptide bridge consists of a diamino acid (m-DAP) that is directly cross-linked to the terminal D-Alanine (D-Ala) of the opposite peptide chain. Red arrows represent possible PGH (endolysin or VAPGH) cleavage sites, including: (1) $N$-acetyl- $\beta$-D-muramidase, (2) $N$-acetyl- $\beta$-D- glucosaminidase, (3) $N$-acetylmuramoyl-L-alanine amidase, (4) L-alanoyl-Dglutamate endopeptidase, (5) interpeptide bridge-specific endopeptidase, and (6) $\gamma$-D-glutaminyl-L-lysine endopeptidase. Figure created with BioRender.com (2020).

\section{Clinical Trials and Case Studies}

Phage PGHs are eligible for FDA (U.S. Food and Drug Administration) fast-track status. This allows the expedition of their review toward approval as drugs for treating serious or life-threatening conditions and otherwise to fulfill unmet medical needs. Currently, seven clinical trials have been launched, all of which target $S$. aureus. In this section, we describe in vitro, clinical, and also pre-clinical (animal testing) analyses of these lysins: P128 ectolysin (VAPGH) (Section 5.1) and endolysins N-Raphasin ${ }^{\circledR}$ SAL200 (Section 5.2), CF-301 (Section 5.3), and Staphefekt SA.100 (Section 5.4). The details of the clinical trials are summarized as well in Table 2. 
Table 2. Clinical trials of phage lytic enzymes.

\begin{tabular}{|c|c|c|c|c|c|c|c|c|c|c|}
\hline Descriptor & Company & Type & Route & Phase & \# & Start & Status & Registry \# & Protocol and Observations & Ref. \\
\hline $\begin{array}{c}\text { P128 } \\
\text { (StaphTAME) }\end{array}$ & GangaGen & Ectolysin & IN & $\mathrm{I} / \mathrm{II}$ & 74 & 2012 & Completed & NCT01746654 & $\begin{array}{l}\text { Type: randomized, double-blind, placebo-controlled study; goal: (1) evaluation of safety, } \\
\text { tolerability via single or multiple doses } \\
\text { ( } 3 \text { doses / day for } 5 \text { days) of } 0.1 \mathrm{mg} \text {, } 0.3 \mathrm{mg} \text {, and } 1 \mathrm{mg} \text { concentrations of P128, } \\
\text { administrated intranasally to healthy individuals; (2) evaluation of safety, tolerability, and } \\
\text { efficacy of P128 in chronic kidney disease patients or any patients who are nasal carriers } \\
\text { of S. aureus or MRSA strain with single dose or } 3 \text { escalating concentrations of P128; Initial } \\
\text { results: drug was well tolerated; results: reduction of nasal carriage }\end{array}$ & NA \\
\hline \multirow{2}{*}{$\begin{array}{l}\text { N- } \\
\text { Rephasin }^{\circledR} \\
\text { SAL200 } \\
\text { (SAL-1, } \\
\text { tonabacase) }\end{array}$} & \multirow[t]{2}{*}{$\begin{array}{l}\text { iNtRON } \\
\text { Biotech- } \\
\text { nology }\end{array}$} & \multirow[t]{2}{*}{ Endolysin } & \multirow[t]{2}{*}{ IV } & I & 36 & 2013 & Completed & NCT01855048 & $\begin{array}{c}\text { Type: randomized, double-blind, placebo-controlled study; goal: evaluation of safety, } \\
\text { pharmacokinetics, and pharmacodynamics } \\
\text { of single intravenous dose of SAL- } 1 \text { at various concentrations: } \\
0.1 \mathrm{mg} / \mathrm{kg}, 0.3 \mathrm{mg} / \mathrm{kg}, 1 \mathrm{mg} / \mathrm{kg}, 3 \mathrm{mg} / \mathrm{kg}, 10 \mathrm{mg} / \mathrm{kg} \text {, administrated } \\
\text { to healthy male individuals; results: no severe side effects observed }\end{array}$ & [157] \\
\hline & & & & II & 25 & 2017 & Terminated $^{1}$ & NCT03089697 & $\begin{array}{c}\text { Type: randomized, double-blind, placebo-controlled study; goal: evaluation of safety and } \\
\text { efficacy of SAL-1 ( }(3 \mathrm{mg} / \mathrm{kg} \text { ), administrated once a day intravenously to individuals with } \\
\text { persistent S. aureus bacteremia; results: serious adverse effects occurred ( } 2 / 12 \text { patients, } \\
16.67 \% \text { of test group), including pneumonia (one patient, } 8.33 \% \\
\text { of test group) and respiratory failure (one patient, } 8.33 \% \text { of test group), as well as several } \\
\text { other minor adverse events (10/12 patients, } 83.33 \% \text { of the test group), e.g., anemia, chills, } \\
\text { back pain, headache, gastrointestinal disorders }\end{array}$ & NA \\
\hline \multirow{3}{*}{$\begin{array}{l}\text { Lysin } \\
\text { CF-301 } \\
\text { (PlySs2, } \\
\text { exebacase) }\end{array}$} & \multirow[t]{3}{*}{ ContraFect } & \multirow[t]{3}{*}{ Endolysin } & \multirow[t]{3}{*}{ IV } & I & 20 & 2015 & Completed & NCT02439359 & $\begin{array}{l}\text { Type: placebo-controlled, dose-escalating study; goal: evaluation } \\
\text { of safety and tolerability of single intravenous dose of CF-301; healthy male and female } \\
\text { individuals; results: CF-301 has a safe profile with no side effects observed }\end{array}$ & [266-270] \\
\hline & & & & II & 121 & 2017 & Completed & NCT03163446 & $\begin{array}{l}\text { Type: multicenter, randomized, double-blind, placebo-controlled study; goal: evaluation } \\
\text { of safety, tolerability, efficacy, and pharmacokinetics of CF-301; study performed in } \\
\text { addition } \\
\text { to standard-of-care antibacterial therapy; adult individuals with bloodstream infections } \\
\text { (bacteremia), including endocarditis }\end{array}$ & [325] \\
\hline & & & & III & 348 & 2019 & Ongoing & NCT04160468 & $\begin{array}{l}\text { Type: randomized, double-blind, placebo-controlled study; goal: evaluation of the } \\
\text { efficacy and safety of a single dose of Exebacase } \\
\text { in addition to standard-of-care antibacterial therapy; adult individuals with bloodstream } \\
\text { infections (bacteremia), including endocarditis }\end{array}$ & NA \\
\hline $\begin{array}{l}\text { Staphefekt } \\
\text { SA.100 }\end{array}$ & Micreos & Endolysin & $\mathrm{T}$ & $\mathrm{I} / \mathrm{II}^{1}$ & 100 & 2016 & Completed & NCT02840955 & $\begin{array}{l}\text { Goal: evaluation on disease severity and skin microbiome; individuals with atopic } \\
\text { dermatitis; results: no side effects observed, decrease in bacterial burden }\end{array}$ & [189] \\
\hline
\end{tabular}

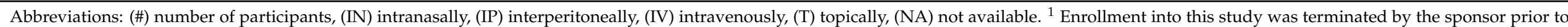
completion of the study. 


\subsection{P128: Anti-Staphylococcal Engineered VAPGH}

P128 is an engineered chimeric protein. It was created by the fusion of Lys16, an $\mathrm{N}$-terminal truncated form of a phage tail-associated ectolysin (VAPGH, gp56) that is encoded by the strictly lytic Staphylococcus phage K, and SH3b, a lysostaphin cell-wallbinding domain encoded by S. simulans [326]. Lys16 consists of a CHAP domain (Cysteine, Histidine-dependent Amidohydrolase/Peptidase) with muralytic activity [326] that can cleave the pentaglycine cross-bridge of peptidoglycan [295,327,328]. These pentaglycines are absent in genera other than staphylococci. P128, therefore, is highly specific to the Staphylococcus genus [329]. P128 otherwise is a potent bactericidal treatment able to target antibiotic-resistant clinical S. aureus strains as well as coagulase-negative (CoNs) staphylococci, such as S. epidermidis, S. haemolyticus, and S. lugdunensis [330]. It is a fast-acting enzyme that can target metabolically active as well as metabolically inactive cells as found either in a planktonic or biofilm-associated state [329].

\subsubsection{P128 In Vitro Activity Analysis}

Various in vitro analyses have shown that P128 can be highly effective against diverse staphylococcal strains. In Paul et al. [326], P128 was shown to be able to kill $>99.9 \%$ of the S. aureus cells at a concentration of $\geq 2.5 \mu \mathrm{g} / \mathrm{mL}$. When a panel of $3000 \mathrm{~S}$. aureus isolates were tested, P128 presented a very broad range of activity, killing $99.9 \%$ of these strains, including MRSA (methicillin-resistant S. aureus), MSSA (methicillin-sensitive S. aureus), and mupirocin-resistant strains (at $10 \mu \mathrm{g} / \mathrm{mL}$ dose) [326] (see also [331]). Additionally, Poonacha et al. [330] reported that $90 \%$ of 62 clinical CoNs were P128-sensitive at P128 concentrations of 16 and $32 \mu \mathrm{g} / \mathrm{mL}$. The broad activity of this drug is probably due to its ability to cleave serine- or alanine-containing pentapeptides [295,330]. Furthermore, MRSA and MSSA 48-h-old biofilms could be reduced up to $95.5 \%$ with $\geq 12.5 \mu \mathrm{g} / \mathrm{mL}$ doses [332] (see also [329]), as well as 72-h-old CoNs-related biofilms formed on the surface of 96-well plates or catheters [328,330]. P128 has also been shown to be effective in vitro in combination with standard-of-care anti-staphylococcal antibiotics $[329,330]$ such as daptomycin [328-330], vancomycin [329,330], linezolid [329,330], gentamicin [329], ciprofloxacin [329], oxacillin [328], and cephazolin [328] - for treatment of sensitive and resistant staphylococcal isolates.

\subsubsection{P128 In Vitro and Ex Vivo Stability and Lack of Cytotoxicity}

P28 has been found to be highly stable in the presence of the divalent cations, calcium, magnesium, and zinc, as well as EDTA, human serum, plasma, whole blood, hyper-immune sera [333], and at a fairly substantial range of temperatures $\left(37-70^{\circ} \mathrm{C}\right)$ [327]. In addition, no cytotoxicity was observed against HEp2 and Vero cell lines [333].

\subsubsection{P128 Resistance}

Sundarrajan et al. [295] identified bacterial resistance occurrence in response to P128 treatment and to the Lys16 domain alone, probably due to alterations in the peptidoglycan cross-bridges (only a single glycine versus pentaglycine cross-bridges in wild type). Bacterial mutants, resistant to Lys16, however, displayed reduced fitness, as indicated by slow growth rates in vitro. These alterations in bacterial fitness may lead to reduced pathogenicity, reduced pathogen survival, or reduced pathogen spreading within communities [295]. Often, mutations were also unstable, with mutants reverting to the wild type. P128-resistant mutants of S. aureus and S. epidermidis also become sensitive to the $\beta$-lactam antibiotics, vancomycin, linezolid, and daptomycin [328], which might occur due to changes in the bacterial cell wall structure [328].

The frequency of $S$. aureus mutation to resistance to P128 is comparable to the lower range value $\left(1 \times 10^{-7}\right)$ of lysostaphin $[295,334]$.

\subsubsection{P128 Animal Testing}

Several pre-clinical in vivo P128 efficacy studies have been done using mice, rats, and dogs. 
Paul et al. [326] tested this enzyme using a rat nasal colonization model. Healthy female Wistar rats (6-7 weeks old) were intranasally inoculated with $10 \mu \mathrm{L}$ of $2 \times 10^{8}$ to $5 \times 10^{8}$ cells $/ \mu \mathrm{L}$ of the MRSA USA300 strain. P128 was administrated twice daily, $24 \mathrm{~h}$ post-infection, in the form of a hydrogel (50 mg/dose containing $100 \mu \mathrm{g}$ P128). Three days of treatment completely decolonized the nasal tissue in $44.4 \%$ of the rats, and, for the rest of the animals, a 2-log reduction in the bacterial burden was observed relative to the negative-treatment control.

Junjappa et al. [286] tested P128 hydrogels on 17 dogs with staphylococcal pyoderma. The treatment was applied daily for 8 days, resulting in complete recovery and no recurrence of symptoms for 2 months.

Sriram et al. [335] explored a bacteremia neutropenic mouse model to evaluate P128 as well as its pharmacokinetics. The half-life of P128 was determined as $5.2 \mathrm{~h}(30 \mathrm{mg} / \mathrm{kg}$ dose) to $5.6 \mathrm{~h}$ (60 mg/ $\mathrm{kg}$ dose), and the maximum bactericidal effect was observed after $30 \mathrm{~min}$ of treatment for all the tested doses $(10,30$, and $60 \mathrm{mg} / \mathrm{kg})$.

Nair et al. [328] tested the efficacy of P128 in combination with oxacillin against MRSA bacteremia in a mouse model. Female BALB/c mice were infected with $10^{9}$ CFU of USA300 strain via IP injection. Next, $2 \mathrm{~h}$ post-infection, a sub-minimal dose of P128 $\left(2.5 \mathrm{mg} \mathrm{kg}^{-1}\right.$, IP) and/or oxacillin (four doses in $4 \mathrm{~h}$ intervals of $100 \mathrm{mg} \mathrm{kg}^{-1}$, intramuscularly) was administrated. The untreated control group died within $12 \mathrm{~h}$ (>80\%), while antibiotic and P128 administrated alone could protect $31 \%$ and $50 \%$ of mice, respectively. Co-treatment, however, protected $81 \%$ of the animals up to $72 \mathrm{~h}$, indicating a therapeutic potential of dual treatment.

Channabasappa et al. [336], in a MRSA bacteremia mouse model, saw similar results. BALB/c mice were challenged with $10^{9}$ CFU of the USA300 strain, IP. Next, the animals were treated with a single dose of P128 $(0.2 \mathrm{mg} / \mathrm{kg}, \mathrm{IP})$ and/or with sub-inhibitory doses of two antibiotics, vancomycin (two doses of $55 \mathrm{mg} / \mathrm{kg}$, subcutaneously, $12 \mathrm{~h}$ intervals) or daptomycin (two doses of $12.5 \mathrm{mg} / \mathrm{kg}$, also subcutaneously with $12 \mathrm{~h}$ intervals). The absence of treatment resulted in $88 \%$ dead animals. Monotherapy resulted in $31 \%, 46 \%$, and $46 \%$ of survival, respectively, for P128, vancomycin, and daptomycin. Co-treatments of P128 and vancomycin or P128 and daptomycin increased mice survival to 85\% and 88\%, respectively.

Channabasappa et al. [337] employed a MRSA bacteremia rat model to further test P128 antibacterial efficacy. The animals were inoculated with $10^{9} \mathrm{CFU}$ of the USA300 strain intravenously with P128 delivered $2 \mathrm{~h}$ post-infection by intravenous bolus administration via the tail vein or by $1 \mathrm{~h}$ infusion by the jugular vein. The untreated group had $80-100 \%$ mortality by day 14, while the survival in the treatment group was dose-dependent. The bolus treatment with $0.5 \mathrm{mg} / \mathrm{kg}$ or $2.5 \mathrm{mg} / \mathrm{kg}$ resulted in $54 \%$ and $100 \%$ survival, respectively, by day 14. The intravenous infusion, $2 \mathrm{~h}$ post-infection, with 10, 2.5, or $0.5 \mathrm{mg} / \mathrm{kg}$ of P128 resulted in $84 \%, 66 \%$, or no effect, respectively. In contrast, $84 \%$ of the rats died in the control untreated group. The treatment with P128 also minimized renal abscess occurrence or abscess size.

\subsubsection{P128 Clinical Trial}

To date, one phase I/II P128-based clinical trial has been conducted (Table 2) (ClinicalTrials.gov identifier NCT01746654). The safety, tolerability, and efficacy in healthy individuals, or various patients that are nasal carriers of $S$. aureus or MRSA strains, were evaluated, with the drug administrated intranasally. The final results of the trial are not available to the public at this moment. The initial results, however, suggested that P128 was well tolerated, with the nasal S. aureus burdens reduced.

\subsection{N-Rephasin ${ }^{\circledR}$ SAL200: Anti-Staphylococcal Recombinant Endolysin}

N-Rephasin ${ }^{\circledR}$ SAL200 (SAL200) is a recombinant SAL-1 endolysin that is naturally encoded by staphylococcal phage SAP-1 [164,338,339]. It is active against both planktonic and biofilm-embedded S. aureus strains, including MRSA [157]. The N-Rephasin ${ }^{\circledR}$ SAL200 stabilizing and enhancing formulation for human application was created in 2013 by Jun et al. [164], consisting of SAL-1 purified by a two-step chromatography, $10 \mathrm{mM}$ of calcium ions, $0.1(w / v)$ 
Poloxamer 188, $0.01 \mathrm{M}$ L-histidine at $\mathrm{pH}$ 6.0, and 5\% (w/v) sorbitol. Antibacterial activity was stable for 8 weeks at $4{ }^{\circ} \mathrm{C}$ and up to $4 \mathrm{~h}$ with constant vigorous agitation.

\subsubsection{N-Rephasin ${ }^{\circledR}$ SAL200 In Vitro Analysis}

A SAL200 preparation was found to be highly effective against all 425 clinical S. aureus isolates tested, including 336 MRSA strains, as well as against pathogens in planktonic and biofilm-related life styles [164]. SAL200 was active not only in broth but also in serum [164].

Kim et al. [256] also assessed the in vitro efficiency of co-treatments with SAL200 and anti-staphylococcal antibiotics (nafcillin and vancomycin). A minimum inhibitory concentration was established between 0.8 and $1.6 \mu \mathrm{g} / \mathrm{mL}$ depending on the S. aureus strain being tested. When this combination treatment was applied against MRSA or MSSA strains, indifferent or synergistic effects were observed. At sub-MIC antibiotic dosages, the SAL200-antibiotic combination rapidly killed the bacteria. However, the bacterial culture subsequently regrew for all the $S$. aureus strains tested.

\subsubsection{N-Rephasin ${ }^{\circledR}$ SAL200 Animal Testing}

Jun et al. [164] used an MRSA ICR mouse model for testing SAL200 efficiency. The animals were infected with $S$. aureus SA2 isolate $\left(1 \times 10^{8} \mathrm{CFU}\right)$ intravenously and subsequently treated with SAL200 at a $12.5 \mathrm{mg} / \mathrm{kg}$ or $25 \mathrm{mg} / \mathrm{kg}$ dose. These treatments consisted of intravenous SAL200 applications at $1 \mathrm{~h}, 25 \mathrm{~h}$, and $49 \mathrm{~h}$ post-infection. The result was a significantly reduced bacterial burden in the bloodstream and splenic tissues (at least a 5-log reduction in comparison to the untreated controls) as well as increased mouse survival over a 5-day period: 9/15 mice died in the control group, 1/15 in the treatment group with a low dose, and no mortality was observed in the higher dose group. Additionally, 2 days post-infection, the negative-treatment control group exhibited several side effects, including erythema of the lid margin, decreased locomotor activity, loss of fur, ptosis, to piloerection and circling, while the mice in both treatment groups behaved normally for the entire experimental period.

The same group [271] also found later that, when SAL200 alone was administrated intravenously into the tail vein of dogs and rats as a single dose, no signs of toxicity in the central nervous system were observed. Only mild adverse effects on respiratory and cardiovascular system functions as well as animal behavior were observed in the case of the dogs. These mild adverse effects included subdued behavior, prone posture, irregular respiration, vomiting, and transient changes in cardiovascular function (one dog, injected with $25 \mathrm{mg} / \mathrm{kg}$ ). The abnormal clinical signs were not observed at any other time during the recovery period, beginning $\sim 10$ days post-injection. In a subsequent part of this study, Jun et al. also considered the impact of repeated SAL200 application, particularly in terms of immune-system interactions. Anti-SAL-1 antibodies were found to be absent from the blood samples at day 14, although they appeared at day 28 in the rats. In the dogs, anti-SAL-1 antibodies instead were detected at day 14. Mild side effects were observed in the repeated-dosing dog model, correlated with decreased C3 complement levels in the blood. It is not clear, however, what stimulated this innate immune system response; i.e., it might have occurred due to the presence of endotoxins in the SAL200 formulation $(<0.5$ endotoxin unit $/ \mathrm{mg})$, or, rather, due to the presence of the enzyme itself. All the experiments were performed according to general laboratory practice and served as a basis for an exploratory phase I clinical trial [157], as presented below.

Kim et al. [256], in an in vivo S. aureus bacteremia mouse SAL200-treatment model, observed decreased bacteria counts in the blood by $\sim 2.2 \log$ and $~ 3.4 \log$ for the MRSA and MSSA strains, respectively, both $1 \mathrm{~h}$ post-treatment. When antibiotics (vancomycin or nafcillin) were co-administrated $1 \mathrm{~h}$ post-infection, bacteria counts in the bloodstream were reduced by 2.1 and $1.6 \log$ for the MRSA and MSSA strains, respectively, in comparison to the untreated controls. In the same study, with the use of a wax moth model, the SAL200 and antibiotic (cefazolin or vancomycin) co-treatment also improved the survival of $S$. aureus infected larvae by $33.3 \%$ for MRSA and $73.3 \%$ for MSSA infection in comparison 
to the untreated group ( $96 \mathrm{~h}$ post-infection). The treatment with just antibiotics increased the survival instead by $6.7 \%$ and $46.7 \%$, respectively, for MRSA and MSSA infections in comparison to the untreated group.

\subsubsection{N-Rephasin ${ }^{\circledR}$ SAL200 Clinical Trial}

In 2013, a phase I randomized, double-blind, placebo-controlled clinical trial was started [157] (Table 2; ClinicalTrials.gov identifier NCT01855048) to evaluate the safety, pharmacokinetics, and pharmacodynamics of intravenous infusions of SAL-1 using single ascending doses $(0.1 \mathrm{mg} / \mathrm{kg}, 0.3 \mathrm{mg} / \mathrm{kg}, 1 \mathrm{mg} / \mathrm{kg}, 3 \mathrm{mg} / \mathrm{kg}$, or $10 \mathrm{mg} / \mathrm{kg})$ administrated to healthy male individuals. This was the first human phase I study of a phage endolysin using intravenous administration. No severe adverse events were seen during observations over the 50 days following SAL200 application and the drug otherwise was tolerated [157]. Mild adverse effects were seen, however, e.g., fatigue, rigors, headache, and myalgia, but were both self-limited and transient. Moreover, no changes in patients' vital signs, ECG, serum chemistry, hematology, or urinalysis test were observed.

The SAL200 half-life in serum ranged from 0.04 to $0.38 \mathrm{~h}$, and maximum concentration in serum was reached between 0.25 to $1.0 \mathrm{~h}$ depending on the dose [157]. Pharmacodynamic properties were also evaluated, but this was done ex vivo, measuring antibacterial activity of blood spotted on an S. aureus lawn as compared with a standard series of SAL200 dilutions [157]. The resulting antibacterial blood activity was approximately proportional to the drug dose, and the minimal bactericidal concentration was established at $0.078 \mu \mathrm{g} / \mathrm{mL}$. The observed clearance of SAL200 from patients was potentially due to proteolysis by plasma proteases. As expected, based on previous monkey studies [272], a humoral immune response to SAL200 was found to be present. Protein-induced antibody production was observed in serum ( 2 to $12 \mu \mathrm{g} / \mathrm{mL}$ ) and was proportional to drug dose [157].

In 2017, a phase II randomized, double-blind, placebo-controlled clinical trial was launched (ClinicalTrials.gov identifier NCT03089697) but terminated prior to completion: "Enrollment into this study was terminated by the Sponsor prior to completion for strategic reasons (to initiate clinical development abroad)". Several minor side effects occurred in $83.33 \%$ of SAL200-treated patients (10 out of 12 tested subjects), including e.g., anemia, chills, back pain, headache, gastrointestinal disorders. In the placebo group, 12 out of 13 patients (92.31\%) experienced various minor side effects. Importantly, two patients out of 12 SAL200-treated (16.67\%) developed severe side effects, i.e., pneumonia or respiratory failure. In the placebo group, also two patients out of thirteen (15.38\%) developed serious side effects, i.e., cardiac disorder due to acute infection, or respiratory failure type 2 . It is not clear why side effects occurred in this clinical study. No results are published except general information placed on ClinicalTrials.gov. Therefore, it is unclear if the side effects occurred due to reaction to SAL-1, level of endotoxins in SAL200 formulations, or maybe due to other co-existing patients morbidities, the infection itself, or other reseaons.

\subsection{CF-301: Anti-Staphylococcal Recombinant Endolysin}

CF-301, also called PlySs2 or exebacase, is a Streptococcus suis prophage-encoded endolysin [143,340]. CF-301 has a modular structure, comprised of an N-terminal cysteinehistidine aminopeptidase (CHAP) catalytic domain and a C-terminal SH3b cell wall binding domain [143]. This enzybiotic has a broad lytic activity against various Gram-positive pathogens including S. aureus [340], S. suis, Listeria spp., Staphylococcus simulans, S. epidermidis, Streptococcus equi, Streptococcus agalactiae (group B streptococcus), S. pyogenes, Streptococcus sanguinis, group G and E streptococci, and Streptococcus pneumoniae [143,340]. CF-301 also has been found to possess anti-biofilm, anti-persister cell, and anti-small-colony variants activities against $S$. aureus [341]. We report here on three clinical trials, phase I, II, and III, that have employed this endolysin, although, as above, we begin with consideration of additional in vitro as well as in vivo properties. 


\subsubsection{CF-301 In Vitro and Ex Vivo Analysis}

Gilmer et al. [143] found that MRSA and S. pyogenes strains could be reduced by 5 logs and 3 logs, respectively, within $1 \mathrm{~h}$ post-CF-301 application. They also found, as with other PGHs, that CF-301 is suitable for various formulation strategies and delivery routes. In addition, $\mathrm{CF}-301$ was found to be stable at a relatively wide range of temperatures $\left(50{ }^{\circ} \mathrm{C}\right.$ for $30 \mathrm{~min}, 37^{\circ} \mathrm{C}$ for $>24 \mathrm{~h}, 4{ }^{\circ} \mathrm{C}$ for 15 days, and $-80{ }^{\circ} \mathrm{C}$ for $>7$ months) and pHs (between $\mathrm{pH} 6$ and 9.7, with optimum at $\mathrm{pH}$ 8), while also being relatively salt- and DTT- (dithiothreitol) resistant. Exposure of MRSA and S. pyogenes to increasing dosages of endolysin (1/32 $\times$ to $4 \times \mathrm{MIC})$ over an 8 -day period, moreover, resulted in no resistance occurrence. Schuch et al. [340] also found that CF-301 treatment could reduce $S$. aureus viable counts (62 strains tested) by $\geq 3$ logs within $30 \mathrm{~min}$ in broth, a rapidity of action consistent with that of other PGHs. Furthermore, they confirmed that CF-301 has a low resistance profile.

CF-301 was also found to work in combination with other antimicrobial agents, such as lysostaphin [340,341], vancomycin, daptomycin, oxacillin, nafcillin, and cefazolin [342]. Bacterial cells could be re-sensitized to antibiotics in the course of CF-301 treatment by enhancing daptomycin and vancomycin binding to bacterial cell walls and membrane [340]. Oh et al. [343] similarly were able to enhance daptomycin activity against $S$. aureus when used in combination with sub-MIC concentrations of CF-301 (as low as $0.001 \times$ to $0.01 \times$ MIC, corresponding to $\sim 1$ to $10 \mathrm{ng} / \mathrm{mL}$ ). They concluded in their study that CF-301 caused an increase in S. aureus membrane permeability, dissipation of membrane potential, and inhibition of virulence phenotypes, including agglutination and biofilm formation.

Schuch et al. [341], in addition, found that mature biofilms of S. pyogenes and S. agalactiae could be disrupted with a MBEC $_{90}$ (minimum biofilm-eradicating concentration) ranging from 0.25 to $8 \mu \mathrm{g} / \mathrm{mL}$. S. aureus biofilms formed on different surfaces, including polystyrene, glass, surgical mesh, catheters, or in the presence of synovial fluid, were also successfully degraded or even completely removed with the use of this pure recombinant protein. The latter included S. aureus biofilms formed on catheters, which could be completely removed within $1 \mathrm{~h}$, with all released bacterial cells killed within $6 \mathrm{~h}$.

Indiani et al. [344] presented evidence of the enhanced potency of CF-301 in combination with human blood components (serum and albumin) and lysozyme, where the latter factors otherwise had no impact on staphylococcal strains (four clinical MSSA, seventy-five clinical MRSA isolates, and twenty-two additional vancomycin-resistant, linezolid-resistant, and daptomycin-resistant $S$. aureus strains). This shows a great potential for this lysin to be used as an adjunct therapeutic toward treating severe systemic infections in humans. Importantly, albumin also substantially increases CF-301 activity, which distinguishes this lysin from small molecule antibiotics.

\subsubsection{CF-301 Animal Testing}

Gilmer et al. [143] infected FVB/NJ mice with MRSA, S. pyogenes, or a mix of both via IP injection $\left(\sim 5 \times 10^{5} \mathrm{CFUs} / \mathrm{mL}\right.$ with $5 \%$ hog gastric mucin in saline). The animals become bacteremic within 1-3 h and infection spread through different organs. CF-301 treatment was applied $3 \mathrm{~h}$ post-infection, delivered as a single dose $(2-4 \mathrm{mg} / \mathrm{mL})$, and it successfully rescued $89 \%$ of the MRSA-infected mice and $94 \%$ of S. pyogenes-infected mice. In the negative-treatment control group, only $6 \%$ and $7 \%$ mice survived MRSA and $S$. pyogenes infection, respectfully. When mixed infections were introduced, only $4 \%$ of mice survived in control group versus $92 \%$ in CF-301 treated over the 10-days period.

Schuch et al. [340], in a MRSA-related BALB/c mouse bacteremia study, found that CF-301 exhibited a dose-dependent activity. Mice were infected with $0.5 \mathrm{~mL}$ of $7.5 \times 10^{6}$ to $1 \times 10^{8}$ CFU MRSA in 5\% mucin, interperitoneally. CF-301 treatment was administrated intraperitoneally $3 \mathrm{~h}$ post-infection at concentrations ranging from 0.25 to $5 \mathrm{mg} / \mathrm{kg}$. High levels of protection ( $70 \%$ of mice) were achieved with $5 \mathrm{mg} / \mathrm{kg}$ over $24 \mathrm{~h}$. Additionally, endolysin treatment resulted in a half-log decrease in bacterial numbers in blood within $15 \mathrm{~min}$ and 2-log decrease with 60 min of treatment. 
Asempa et al. [345] determined the combined impacts of CF-301 and subtherapeutic daptomycin treatments against $S$. aureus in a neutropenic murine thigh infection model. Daptomycin treatment alone applied $2 \mathrm{~h}$ post-infection resulted in a mean growth of only $0.39 \pm 1.19 \log$ in CFUs/thigh in comparison to $8.28 \pm 0.47 \log$ CFUs/thigh in the untreated control group. Treatment with CF-301 alone resulted in mean growth instead of only $0.76 \pm 1.24 \mathrm{log}$ CFUs/thigh for $15 \mathrm{mg} / \mathrm{kg}$ dose while a $90 \mathrm{mg} / \mathrm{kg}$ dose reduced bacterial growth to $-0.26 \pm 1.25-\log$ of CFUs/thigh. Co-treatment with $15 \mathrm{mg} / \mathrm{kg} \mathrm{CF}-$ 301 and daptomycin resulted in a mean growth also of $-1.03 \pm 0.72 \log$ CFUs/thigh Introducing higher doses of CF-301 did not yield further killing in co-treatment. Thus, CF301 at the higher dose, when used alone, appeared to be superior to daptomycin treatment, with no improvements seen with combined treatment, and with superior effectiveness seen when combining daptomycin treatments with the lower CF-301 dose.

In the MRSA septicemia model, conducted by the same group [345], a high MRSA inoculum $\left(1 \times 10^{9} \mathrm{CFU}\right)$ was administrated IP, followed by treatment with CF-301, daptomycin, or co-treatment using both drugs, delivered $2 \mathrm{~h}$ post-infection. Treatment with CF-301 alone rescued $17-50 \%$ of mice at $72 \mathrm{~h}$ post-infection, while antibiotic treatment alone resulted in only 7-31\% survival. Co-treatment, however, improved mice survival to $82-90 \%$, clearly presenting synergistic effect of both drugs.

\subsubsection{CF-301 Clinical Trials}

In 2015, CF-301 was subjected to a phase I clinical trial (Table 2; ClinicalTrials.gov identifier NCT02439359) focusing on the safety and tolerability of single intravenous dose as administrated to healthy individuals. CF-301 was found generally to be safe and well tolerated, with no serious side effects observed. Inflammatory responses to the drug were evaluated using a range of inflammatory markers, e.g., high-sensitivity C-reactive protein, the erythrocyte sedimentation rate, and complement factors $\mathrm{Bb}, \mathrm{C} 3 \mathrm{a}, \mathrm{C} 5 \mathrm{a}$ and $\mathrm{CH} 50$, but no differences were observed between placebo- and CF-301-treated groups [268]. Furthermore, no clinically relevant changes were found in heart rate, QT interval in electrocardiograms, or either systolic or diastolic blood pressure [269].

CF-301 was the first phage-derived PGH to be entered into a phase II clinical trial (ClinicalTrials.gov identifier NCT03163446), which was a randomized, double-blind, placebocontrolled, superiority-design, first-in-patient, proof of concept study conducted between 2017 and 2019 in 11 countries [325]. The trial involved the treatment of 121 patients with and without antibiotic co-treatment for bacteremia, including endocarditis, of which 116 patients had confirmed S. aureus infections, including by MRSA and MSSA strains [346]. The efficacy analysis of CF-301 treatment showed a greater frequency of clinical responders for MRSA infections on a day 14 with the co-treatment subgroup than with the comparison, antibiotic-only subgroup ( $92.6 \%$ vs. $75 \%$ ). In MSSA subgroup, however, little difference was observed, i.e., $88.6 \%$ versus $90 \%$, respectively, perhaps because the response to antibiotic treatment alone was already quite high with this subgroup [325]. Importantly, in MRSA subgroup, mortality rate at day 30 was $3.7 \%$ in co-treatment subgroup versus $25 \%$ in antibiotic-alone subgroup. The results of this trial are considered, however, more as proof-of concept rather than confirmatory.

Note, that CF-301 endolysin was considered to be generally safe and well tolerated by the patients, with no hypersensitivity reactions. In addition, although $20.8 \%$ and $14.9 \%$ of the patients had preexisting CF-301-antibodies in the co-treatment and antibiotics-alone subgroups, respectively, these antibodies did not affect the efficacy or safety outcomes of CF-301 treatments.

In 2019, a phase III clinical trial was launched (ClinicalTrials.gov identifier NCT04160468) evaluating the efficacy and safety of a single dose of CF-301 in addition to standard-of-care antibacterial therapy in adult individuals with bloodstream infections (bacteremia), again including endocarditis. The results are not yet publicly available. Anastasiou et al. [347] reported at p. S320, however, that there were " $42.8 \%$ higher clinical responder rates with a 
single dose of exebacase used in addition to standard of care antibiotics (SOC) vs. SOC alone for the treatment of methicillin-resistant S. aureus (MRSA) bacteremia including endocarditis".

\subsection{Staphefekt SA.100: Anti-Staphylococcal Engineered Endolysin}

Staphefekt SA.100 is an engineered phage endolysin with endopeptidase and putative amidase activity. It is used to treat skin infections caused by S. aureus, including by MRSA and MSSA strains [212]. It is registered as a medical device in Europe (class 1) and available in pharmacies there as an over-the-counter medicine in the form of a cream and gel [348]. Staphefekt is somewhat specific to $S$. aureus and does not affect commensal bacteria, even during long-term applications. This allows treatment of atopic dermatitis flares with reduced topical corticosteroid application [349-351]. Importantly, to date, no bacterial resistance to this endolysin has been identified [348-351], even with long-term daily usage to treat chronic and recurrent $S$. aureus infections [212].

\subsubsection{Staphefekt SA.100 In Vitro Analysis}

An in vitro analysis with the use of a lysis assay showed that Staphefekt $(30 \mathrm{mg} / \mathrm{mL})$ was active against 28 MSSA and 8 MRSA strains (58.6\% vs. 54.1\% OD reduction, respectively in comparison to untreated controls) [349]. S. epidermidis, S. hominis, Staphylococcus haemolyticus, and Staphylococcus lugdunensis strains, on the other hand, were only minimally impacted (1-15\% reduction) [349]. Further analysis also presented equivalent susceptibility for MRSA and MSSA strains (2 to $3 \log$ CFUs $/ \mathrm{mL}$ reduction in culture within $4 \mathrm{~h}$ and no discrepancies in MIC analysis).

\subsubsection{Staphefekt SA.100 Clinical Trial}

In 2016, Staphefekt SA.100 was subject to a phase I/II clinical trial (Table 2; ClinicalTrials.gov identifier NCT02840955) focusing on its impact on S. aureus infections, the skin microbiome, disease severity, quality of life, and corticosteroid co-treatment (triamcinolone). One hundred participants with moderate-to-severe atopic dermatitis were treated with a cetomacrogol-based cream for 12 weeks [189], with the drug well tolerated by patients. There currently is a lack of information about the impact of the drug on corticosteroid usage and dosing, however, mainly due to patient lack of compliance with the combination treatment, hampering the study size. Moreover, 21 Staphefekt-naive healthy human donors were tested and pre-existing IgG antibodies recognizing Staphefekt epitopes were identified. The authors suggest that this is probably due to daily $S$. aureus exposure, including, presumably, also to their phages and lysins. Staphefekt is now in preparation for a phase III clinical trial to evaluate its efficiency against $S$. aureus infections found in association with eczema in comparison to topical antibiotics.

\subsubsection{Staphefekt SA.100 Case Study Series}

Totté et al. [212] presented three case studies based on Staphefekt SA.100 topical treatment of dermatosis associated with $S$. aureus colonization. In the first case, a 23-yearold male was reluctant to use oral antibiotics and instead was treated with Staphefekt SA.100 twice daily for two weeks, with a reported (p. 20) "strong decrease of inflammatory symptoms that started within a few days." The symptoms returned within 1 week of cessation of treatment, however, suggesting that only control had been achieved rather than elimination of the $S$. aureus. In the second case, a 63-year-old male was treated for impetigo with various antibiotics, with flucloxacillin resulting in clinical improvement, although this improvement persisted only over the course of treatment. The symptoms were abolished over a subsequent 12-week treatment with Staphefekt, as combined with the anti-inflammatory betamethasone, although again $S$. aureus was not eliminated. The third case also involved a 23-year-old male who had been treated as well with flucloxacillin, resulting in the temporary improvement of symptoms. As with the first two cases, substantial improvement was seen with subsequent Staphefekt treatment. The authors concluded that (p. 22), "We believe that Staphefekt induces a clinically relevant reduction of S. aureus 
rather than a total eradication." Micreos, which provides this endolysin commercially, also reports a customer satisfaction rating of over $80 \%$ in their customer questionnaires [189].

\subsection{Development of Enzybiotics Targeting Gram-Negative Bacteria towards Clinical Trials}

Currently, to our knowledge, there are no registered clinical trials with the use of phage-based enzybiotics targeting Gram-negative pathogens. Nevertheless, several research groups have applied synthetic biology approaches to engineer phage PGHs to tackle Gram-negative pathogens. The difficulties in phage lysin-based treatments against Gram-negative pathogens occur mainly due to the problem of bacterial outer membrane penetration. Hybrid proteins are, therefore, created by the fusion of PGHs with different outer membrane permeabilizing peptides. Alternatively, completely new chimeric proteins can be created with new features with the use of, e.g., the VersaTile shuffling method [309,310].

In Europe, Lysando AG has prepared Artilysins ${ }^{\circledR}$-based drugs with antibacterial properties against Gram-positive and Gram-negative pathogens. Since 2014, they developed Artilysins ${ }^{\circledR}$ against Campylobacter spp., S. aureus, Staphylococcus spp., P. aeruginosa, Streptococcus uberis, Salmonella spp., E. coli, Vibro spp., Neisseria gonorrhoeae, A. baumannii, K. pneumoniae, Cutibacterium acnes, as well as several with dual activity, targeting P. aeruginosa and Enterobacteriaceae, Enterococcus faecalis and E. faecium, Streptococcus dysgalactiae and S. agalactiae, or Enterococcus spp. and Streptococcus spp. [352]. Lysando AG is currently working toward obtaining licensees in animal feed areas as well as starting patient treatment with Artilysins ${ }^{\circledR}$-based wound care sprays (Medolysin ${ }^{\circledR}$ ) with antibacterial and wound healing properties.

According to the Lysando AG website, the recruited patients were treated daily for more than 30 days or every 2-3 days up to a maximum of five applications. The wound healing process was improved immediately post-application in $90 \%$ of the subjects, leading to up to $40 \%$ completely healed wounds within 30 days. Moreover, the patient life quality was improved, including pain and inflammation reduction. Additionally, the chronic MRSA decubitus infection of one coma patient was completely healed after 27 months of treatment, with the first signs of wound healing beginning within 2 weeks of the start of treatment [352]. However, clinical publications to support these claims do not exist.

\section{Advantages and Challenges}

Phage-based enzybiotics present a promising alternative antimicrobial therapy. Currently, the most progress has been achieved with PGHs, which provide both activity and high efficiency against many clinically relevant pathogens. They have distinctive modes of action, relative to standard antibiotics, and can be applied as stand-alone therapies as well as in combination with other antimicrobials. Importantly, the possibility of the occurrence of resistance appears to be low, although some cases of acquired resistance have been observed with engineered endolysins, as documented in Section 5.1.3. Furthermore, PGHs often are highly specific to their bacterial targets, having therefore a minimal impact on the microbiome in contrast to many antibiotics. Therapy with phage-derived enzybiotics can also be used to tackle not only planktonic but also biofilm-embedded bacteria.

In comparison to whole phages, protein-based enzybiotics do not require replication in association with their hosts, which often are pathogenic bacteria. This is especially problematic with large-scale industrial phage production, where additional containment measures thereby need to be assured. In contrast, methods of recombinant protein production are well developed, and some of these approaches do not require even bacterial involvement. Phage replication in the presence of bacterial hosts can also be problematic in terms of the repeatability of the phage titers to which targeted bacteria are exposed during treatments. Additionally, there is a risk that phages may mutate and, at least in theory, change specificity as well as promote gene exchange between bacteria. All of these issues can be avoided with the use of protein-based enzybiotics. 
Both phages and enzybiotics can induce immune responses and, often, the production of anti-phage or anti-enzyme antibodies is observed. Nevertheless, it seems that host immune system responses do not have substantial negative impacts on the therapeutic outcomes of either phage or enzybiotic treatments. Moreover, the duration of the treatments, dosages, delivery routes, and immune status of patients may influence the immune response, which often is case-specific [53].

PGHs can tackle Gram-positive and Gram-negative bacteria, although, as discussed in Section 5.5, targeting Gram-negative pathogens is not always straightforward as it requires overcoming the outer membrane barrier. Currently, the most explored tactic is protein engineering, allowing for PGH fusion with outer membrane permeabilizing peptides. This approach also opens the possibility for various modifications of protein properties and the shuffling of PGH's domains, increasing the diversity and specificity of the available antibacterial proteins.

The phage enzybiotic field is new and there is a limited amount of data concerning their safety, pharmacokinetics, and pharmacodynamics, e.g., [230,255,271]. Over the course of treatment, there is a risk, e.g., of releasing pathogen-associated molecular patterns (PAMPs), such as LPS, from bacteria upon their lysis [53,353]. This can lead to severe side effects, including endotoxic shock. The results from animal models and first clinical trials, however, are both promising and present safe profiles for PGHs. The N-Rephasin ${ }^{\circledR}$ clinical trials data are concerning at this moment, however, although without publication and discussion from the company side it is difficult to assess the outcomes of these trials, including whether endolysin itself leads to severe side effects or if other factors played a role.

There are also other bottlenecks in enzybiotic development. These include delivery routes and methods. In the literature, most phage-derived enzymes are applied only topically. Systemic, oral delivery, or topical delivery into the lungs are more challenging. Enzymatic conformations and activities can be affected by changes in $\mathrm{pH}$ in the digestive system, by the activity of different enzymes, such as proteases or peptidases, or the activity of alveolar macrophages [53,354,355]. Patients alternatively can be exposed to secondary bacterial infections when a drug is administrated intravenously. To overcome these obstacles, several different approaches are currently under investigation, such as liposome encapsulation [356], encapsulation within Poly ( $N$-isopropylacrylamide) nanoparticles [357], or PGH fusion with bacteriocins that allow these enzybiotics to cross the outer membrane ("lysocins" [358]). Important consideration is also necessary regarding the protein size as this can limit drug delivery to bacterial infections, e.g., as involving penetration through nasal mucosa or gut epithelia, or deposition into lungs [359]. This is especially a concern when proteins are engineered and fused with additional peptides or domains as this has the effect of increasing overall protein size.

Finally, an important hurdle is also approval from drug regulatory agencies, such as the EMA (European Medical Agency) in Europe or the FDA (Food and Drug Administration) in the USA. PGHs and PSDs are produced via recombinant DNA technologies and are also often engineered, making routes toward approval as well as launching clinical trials more complicated. To date, there is only one endolysin-based product, Staphefekt SA.100, which is available in Europe as a medical product. Its regulatory approval, however, is suggestive of a bright future for the clinical use of enzybiotics to treat common bacterial infections.

\section{Conclusions}

In the context of the worldwide antibiotic crisis, new alternative therapies are in grave need. Phage-derived enzybiotics represent a promising and novel class of therapeutics for human and animal applications. They demonstrate strong anti-biofilm and antibacterial properties in vitro, in vivo, and in human studies. They are, in general, considered to be safe, non-toxic agents that are active against multi-drug-resistant Gram-negative and Grampositive pathogens as well as persister cells, with low probability of bacterial resistance occurrence, the latter especially for peptidoglycan hydrolases (PGHs). Enzybiotics can also be applied as adjuvants or co-treatments to standard-of-care antibiotics. Nevertheless, 
additional research is still necessary toward further improvement of these therapies as well as their regulatory approval for clinical use.

Author Contributions: K.M.D.-W. had primary writing responsibilities and drafted the manuscript. S.T.A. initiated and was substantially involved in the completion of the manuscript. D.J.W. contributed to the manuscript's further development. All authors have read and agreed to the published version of the manuscript.

Funding: This research was funded by Public Health Service grants R21AI156304 (S.T.A.), R01AI34895, R21AI119116, R01AI143916 (D.J.W.), and in part by the Cure CF Columbus (C3) Training Grant Program. C3 is supported by the Cystic Fibrosis Foundation (Research Development Program, grant MCCOY19RO) (K.M.D.-W.).

Conflicts of Interest: S.T.A. has consulted for and served on advisory boards for companies with phage therapy interests, holds an equity stake in a number of these companies, and maintains the websites phage.org and phage-therapy.org. No additional competing financial interests exist. The text presented represents the perspectives of the authors alone, and no outside help was received in its writing.

\section{References}

1. Quinn, R. Rethinking antibiotic research and development: World War II and the penicillin collaborative. Am. J. Public Health 2013, 103, 426-434. [CrossRef] [PubMed]

2. Landecker, H. Antimicrobials before antibiotics: War, peace, and disinfectants. Palgrave Commun. 2019, 5, 45. [CrossRef]

3. Bud, R. Penicillin: Triumph and Tragedy; Oxford University Press on Demand: New York, NY, USA, 2007.

4. Kirby, W.M. Extraction of a highly potent penicillin inactivator from penicillin resistant staphylococci. Science 1944, $99,452-453$. [CrossRef] [PubMed]

5. Barber, M.; Rozwadowska-Dowzenko, M. Infection by penicillin-resistant staphylococci. Lancet 1948, 2, 641-644. [CrossRef]

6. Shaffer, R.K. The challenge of antibiotic-resistant Staphylococcus: Lessons from hospital nurseries in the mid-20th century. Yale J. Biol. Med. 2013, 86, 261-270.

7. Ventola, C.L. The antibiotic resistance crisis: Part 1: Causes and threats. Pharm. Ther. 2015, 40, $277-283$.

8. Aslam, B.; Wang, W.; Arshad, M.I.; Khurshid, M.; Muzammil, S.; Rasool, M.H.; Nisar, M.A.; Alvi, R.F.; Aslam, M.A.; Qamar, M.U. Antibiotic resistance: A rundown of a global crisis. Infect. Drug Resist. 2018, 11, 1645. [CrossRef]

9. Steenbergen, J.N.; Alder, J.; Thorne, G.M.; Tally, F.P. Daptomycin: A lipopeptide antibiotic for the treatment of serious Grampositive infections. J. Antimicrob. Chemother. 2005, 55, 283-288. [CrossRef]

10. Chakravarty, I.; Kundu, K.; Kundu, S. Daptomycin: Discovery, development and perspectives. Battle Against Microb. Pathog. Basic Sci. Technol. Adv. Educ. Progr. 2015, 2, 895-903.

11. Nelson, D.; Loomis, L.; Fischetti, V.A. Prevention and elimination of upper respiratory colonization of mice by group A streptococci by using a bacteriophage lytic enzyme. Proc. Natl. Acad. Sci. USA 2001, 98, 4107-4112. [CrossRef]

12. Clokie, M.R.; Kropinski, A.M.; Lavigne, R. Bacteriophages; Springer: New York, NY, USA, 2009.

13. Clokie, M.R.; Millard, A.D.; Letarov, A.V.; Heaphy, S. Phages in nature. Bacteriophage 2011, 1, 31-45. [CrossRef]

14. Catalao, M.J.; Gil, F.; Moniz-Pereira, J.; Sao-Jose, C.; Pimentel, M. Diversity in bacterial lysis systems: Bacteriophages show the way. FEMS Microbiol. Rev. 2013, 37, 554-571. [CrossRef]

15. Rodríguez-Rubio, L.; Martínez, B.; Donovan, D.M.; García, P.; Rodríguez, A. Potential of the virion-associated peptidoglycan hydrolase HydH5 and its derivative fusion proteins in milk biopreservation. PLoS ONE 2013, 8, e54828.

16. Rodríguez-Rubio, L.; Gutiérrez, D.; Donovan, D.M.; Martínez, B.; Rodríguez, A.; García, P. Phage lytic proteins: Biotechnological applications beyond clinical antimicrobials. Crit. Rev. Biotechnol. 2016, 36, 542-552. [CrossRef]

17. Shen, Y.; Mitchell, M.S.; Donovan, D.M.; Nelson, D.C. 15 Phage-based enzybiotics. Bacteriophages Health Dis. $2012,24,217$.

18. Knecht, L.E.; Veljkovic, M.; Fieseler, L. Diversity and function of phage encoded depolymerases. Front. Microbiol. 2020, 10, 2949. [CrossRef]

19. Pestrak, M.J.; Baker, P.; Dellos-Nolan, S.; Hill, P.J.; da Silva, D.P.; Silver, H.; Lacdao, I.; Raju, D.; Parsek, M.R.; Wozniak, D.J. Treatment with the Pseudomonas aeruginosa glycoside hydrolase PslG combats wound infection by improving antibiotic efficacy and host innate immune activity. Antimicrob. Agents Chemother. 2019, 63, e00234-19. [CrossRef]

20. Zhang, J.; Wu, H.; Wang, D.; Zhang, C.; Zhao, K.; Ma, L. Intracellular glycosyl hydrolase PslG shapes bacterial cell fate, signaling, and the biofilm development of Pseudomonas Aeruginosa. bioRxiv 2021. [CrossRef]

21. Biswas, R.; Voggu, L.; Simon, U.K.; Hentschel, P.; Thumm, G.; Götz, F. Activity of the major staphylococcal autolysin Atl. FEMS Microbiol. Lett. 2006, 259, 260-268. [CrossRef]

22. Qin, Z.; Ou, Y.; Yang, L.; Zhu, Y.; Tolker-Nielsen, T.; Molin, S.; Qu, D. Role of autolysin-mediated DNA release in biofilm formation of Staphylococcus epidermidis. Microbiology 2007, 153, 2083-2092. [CrossRef]

23. Porayath, C.; Suresh, M.K.; Biswas, R.; Nair, B.G.; Mishra, N.; Pal, S. Autolysin mediated adherence of Staphylococcus aureus with fibronectin, gelatin and heparin. Int. J. Biol. Macromol. 2018, 110, 179-184. [CrossRef] 
24. Parisien, A.; Allain, B.; Zhang, J.; Mandeville, R.; Lan, C. Novel alternatives to antibiotics: Bacteriophages, bacterial cell wall hydrolases, and antimicrobial peptides. J. Appl. Microbiol. 2008, 104, 1-13. [CrossRef]

25. Riley, M.A.; Wertz, J.E. Bacteriocins: Evolution, ecology, and application. Annu. Rev. Microbiol. 2002, 56, 117-137. [CrossRef]

26. Cotter, P.D.; Ross, R.P.; Hill, C. Bacteriocins-A viable alternative to antibiotics? Nat. Rev. Microbiol. 2013, 11, 95-105. [CrossRef]

27. Borysowski, J.; Gorksi, A. Enzybiotics and Their Potential Applications in Medicine; Wiley: New York, NY, USA, 2010 ; pp. 1-26.

28. Yang, S.-C.; Lin, C.-H.; Sung, C.T.; Fang, J.-Y. Antibacterial activities of bacteriocins: Application in foods and pharmaceuticals. Front. Microbiol. 2014, 5, 241.

29. Oliver, W.T.; Wells, J.E. Lysozyme as an alternative to growth promoting antibiotics in swine production. J. Anim. Sci. Biotechnol. 2015, 6, 35. [CrossRef]

30. Veiga-Crespo, P.; Ageitos, J.M.; Poza, M.; Villa, T.G. Enzybiotics: A look to the future, recalling the past. J. Pharm. Sci. 2007, 96, 1917-1924. [CrossRef]

31. Slopek, S.; Weber-Dabrowska, B.; Dabrowski, M.; Kucharewicz-Krukowska, A. Results of bacteriophage treatment of suppurative bacterial infections in the years 1981-1986. Arch. Immunol. Ther. Exp. 1987, 35, 569-583.

32. Abedon, S.T. Phage-antibiotic combination treatments: Antagonistic impacts of antibiotics on the pharmacodynamics of phage therapy? Antibiotics 2019, 8, 182. [CrossRef]

33. Schooley, R.T.; Biswas, B.; Gill, J.J.; Hernandez-Morales, A.; Lancaster, J.; Lessor, L.; Barr, J.J.; Reed, S.L.; Rohwer, F.; Benler, S. Development and use of personalized bacteriophage-based therapeutic cocktails to treat a patient with a disseminated resistant Acinetobacter baumannii infection. Antimicrob. Agents Chemother. 2017, 61, e00954-17. [CrossRef]

34. Tkhilaishvili, T.; Lombardi, L.; Klatt, A.-B.; Trampuz, A.; Di Luca, M. Bacteriophage Sb-1 enhances antibiotic activity against biofilm, degrades exopolysaccharide matrix and targets persisters of Staphylococcus aureus. Int. J. Antimicrob. Agents 2018, 52, 842-853. [CrossRef] [PubMed]

35. Ferry, T.; Boucher, F.; Fevre, C.; Perpoint, T.; Chateau, J.; Petitjean, C.; Josse, J.; Chidiac, C.; L'hostis, G.; Leboucher, G. Innovations for the treatment of a complex bone and joint infection due to XDR Pseudomonas aeruginosa including local application of a selected cocktail of bacteriophages. J. Antimicrob. Chemother. 2018, 73, 2901-2903. [CrossRef] [PubMed]

36. Abedon, S.T. Bacteriophages and Biofilms; Nova Science Publishers, Inc.: Hauppauge, NY, USA, 2011.

37. Kutateladze, M.; Adamia, R. Phage therapy experience at the Eliava Institute. Med. Mal. Infect. 2008, 38, 426-430. [CrossRef] [PubMed]

38. Chanishvili, N. Literature Review of The Practical Application of Bacteriophage Research; Nova Science Publishers, Inc.: Hauppauge, NY, USA, 2012.

39. Weber-Dabrowska, B.; Mulczyk, M.; Gorski, A. Bacteriophage therapy of bacterial infections: An update of our institute's experience. Arch. Immunol. Exp. 2000, 48, 547-551.

40. Międzybrodzki, R.; Borysowski, J.; Weber-Dabrowska, B.; Fortuna, W.; Letkiewicz, S.; Szufnarowski, K.; Pawełczyk, Z.; Rogóż, P.; Kłak, M.; Wojtasik, E. Clinical aspects of phage therapy. Adv. Virus Res. 2012, 83, 73-121.

41. Leitner, L.; Ujmajuridze, A.; Chanishvili, N.; Goderdzishvili, M.; Chkonia, I.; Rigvava, S.; Chkhotua, A.; Changashvili, G.; McCallin, S.; Schneider, M.P. Intravesical bacteriophages for treating urinary tract infections in patients undergoing transurethral resection of the prostate: A randomised, placebo-controlled, double-blind clinical trial. Lancet Infect. Dis. 2021, 21, 427-436. [CrossRef]

42. Letkiewicz, S.; Międzybrodzki, R.; Kłak, M.; Jończyk, E.; Weber-Dąbrowska, B.; Górski, A. The perspectives of the application of phage therapy in chronic bacterial prostatitis. FEMS Immunol. Med. Microbiol. 2010, 60, 99-112. [CrossRef]

43. Gupta, P.; Singh, H.S.; Shukla, V.K.; Nath, G.; Bhartiya, S.K. Bacteriophage therapy of chronic nonhealing wound: Clinical study. Int. J. Low. Extrem. Wounds 2019, 18, 171-175. [CrossRef]

44. Aslam, S.; Lampley, E.; Wooten, D.; Karris, M.; Benson, C.; Strathdee, S.; Schooley, R.T. Lessons learned from the first 10 consecutive cases of intravenous bacteriophage therapy to treat multidrug-resistant bacterial infections at a single center in the United States. In Open Forum Infectious Diseases; Oxford University Press: Oxford, UK, 2020; p. ofaa389.

45. Tkhilaishvili, T.; Winkler, T.; Müller, M.; Perka, C.; Trampuz, A. Bacteriophages as adjuvant to antibiotics for the treatment of periprosthetic joint infection caused by multidrug-resistant Pseudomonas aeruginosa. Antimicrob. Agents Chemother. 2019, 64, e00924-19. [CrossRef]

46. Rogóż, P.; Amanatullah, D.F.; Międzybrodzki, R.; Manasherob, R.; Tikunova, N.V.; Weber-Dąrowska, B.; Fortuna, W.; Letkiewicz, S.; Górski, A. Phage therapy in orthopaedic implant-associated infections. In Phage Therapy: A Practical Approach; Springer: Cham, Switzerland, 2019; pp. 189-211.

47. Abedon, S.T.; Danis-Wlodarczyk, K.M.; Alves, D.R. Phage therapy in the 21st century: Is there modern, clinical evidence of phage-mediated efficacy? Pharmaceuticals 2021, 14, 1157. [CrossRef]

48. Mulani, M.S.; Kamble, E.E.; Kumkar, S.N.; Tawre, M.S.; Pardesi, K.R. Emerging strategies to combat ESKAPE pathogens in the era of antimicrobial resistance: A review. Front. Microbiol. 2019, 10, 539. [CrossRef]

49. Santajit, S.; Indrawattana, N. Mechanisms of antimicrobial resistance in ESKAPE pathogens. BioMed Res. Int. 2016, $2016,2475067$. [CrossRef]

50. Loc-Carrillo, C.; Abedon, S.T. Pros and cons of phage therapy. Bacteriophage 2011, 1, 111-114. [CrossRef]

51. Pirnay, J.-P.; Kutter, E. Bacteriophages: It's a medicine, Jim, but not as we know it. Lancet Infect. Dis. 2020, 21, 309-311. [CrossRef] 
52. Pirnay, J.-P.; Verbeken, G.; Rose, T.; Jennes, S.; Zizi, M.; Huys, I.; Lavigne, R.; Merabishvili, M.; Vaneechoutte, M.; Buckling, A. Introducing yesterday's phage therapy in today's medicine. Future Virol. 2012, 7, 379-390. [CrossRef]

53. Murray, E.; Draper, L.A.; Ross, R.P.; Hill, C. The advantages and challenges of using endolysins in a clinical setting. Viruses 2021, 13, 680. [CrossRef]

54. Nelson, D.C.; Schmelcher, M.; Rodriguez-Rubio, L.; Klumpp, J.; Pritchard, D.G.; Dong, S.; Donovan, D.M. Endolysins as antimicrobials. In Advances in Virus Research; Elsevier: Cambridge, CA, USA, 2012; Volume 83, pp. $299-365$.

55. Maciejewska, B.; Olszak, T.; Drulis-Kawa, Z. Applications of bacteriophages versus phage enzymes to combat and cure bacterial infections: An ambitious and also a realistic application? Appl. Microbiol. Biotechnol. 2018, 102, 2563-2581. [CrossRef]

56. Azeredo, J.; García, P.; Drulis-Kawa, Z. Targeting biofilms using phages and their enzymes. Curr. Opin. Biotechnol. 2021, 68, 251-261. [CrossRef]

57. Maszewska, A. Phage associated polysaccharide depolymerases-characteristics and application. Postepy Hig. Med. Dosw. 2015, 69, 690-702. [CrossRef]

58. Pires, D.P.; Oliveira, H.; Melo, L.D.; Sillankorva, S.; Azeredo, J. Bacteriophage-encoded depolymerases: Their diversity and biotechnological applications. Appl. Microbiol. Biotechnol. 2016, 100, 2141-2151. [CrossRef]

59. Love, M.J.; Bhandari, D.; Dobson, R.C.; Billington, C. Potential for bacteriophage endolysins to supplement or replace antibiotics in food production and clinical care. Antibiotics 2018, 7, 17. [CrossRef]

60. Divya Ganeshan, S.; Hosseinidoust, Z. Phage therapy with a focus on the human microbiota. Antibiotics 2019, 8, 131. [CrossRef]

61. Heselpoth, R.D.; Swift, S.M.; Linden, S.B.; Mitchell, M.S.; Nelson, D.C. Enzybiotics: Endolysins and bacteriocins. In Bacteriophages: Biology, Technology, Therapy; Springer: Cham, Switzerland, 2021; pp. 989-1030.

62. Dams, D.; Briers, Y. Enzybiotics: Enzyme-based antibacterials as therapeutics. In Therapeutic Enzymes: Function and Clinical Implications; Springer: Singapore, 2019; pp. 233-253.

63. Mirski, T.; Lidia, M.; Nakonieczna, A.; Gryko, R. Bacteriophages, phage endolysins and antimicrobial peptides-The possibilities for their common use to combat infections and in the design of new drugs. Ann. Agric. Environ. Med. 2019, 26, 203-209. [CrossRef]

64. Rodríguez-Rubio, L.; Martínez, B.; Donovan, D.M.; Rodríguez, A.; García, P. Bacteriophage virion-associated peptidoglycan hydrolases: Potential new enzybiotics. Crit. Rev. Microbiol. 2013, 39, 427-434. [CrossRef]

65. Hermoso, J.A.; García, J.L.; García, P. Taking aim on bacterial pathogens: From phage therapy to enzybiotics. Curr. Opin. Microbiol. 2007, 10, 461-472. [CrossRef]

66. Latka, A.; Maciejewska, B.; Majkowska-Skrobek, G.; Briers, Y.; Drulis-Kawa, Z. Bacteriophage-encoded virion-associated enzymes to overcome the carbohydrate barriers during the infection process. Appl. Microbiol. Biotechnol. 2017, 101, 3103-3119. [CrossRef] [PubMed]

67. Briers, Y.; Lavigne, R. Breaking barriers: Expansion of the use of endolysins as novel antibacterials against Gram-negative bacteria. Future Microbiol. 2015, 10, 377-390. [CrossRef] [PubMed]

68. Tsonos, J.; Vandenheuvel, D.; Briers, Y.; De Greve, H.; Hernalsteens, J.-P.; Lavigne, R. Hurdles in bacteriophage therapy: Deconstructing the parameters. Vet. Microbiol. 2014, 171, 460-469. [CrossRef] [PubMed]

69. Abdelkader, K.; Gerstmans, H.; Saafan, A.; Dishisha, T.; Briers, Y. The preclinical and clinical progress of bacteriophages and their lytic enzymes: The parts are easier than the whole. Viruses 2019, 11, 96. [CrossRef] [PubMed]

70. Adams, M.H.; Park, B.H. An enzyme produced by a phage-host cell system: II. The properties of the polysaccharide depolymerase. Virology 1956, 2, 719-736. [CrossRef]

71. Hughes, K.; Sutherland, I.; Clark, J.; Jones, M. Bacteriophage and associated polysaccharide depolymerases-novel tools for study of bacterial biofilms. J. Appl. Microbiol. 1998, 85, 583-590. [CrossRef]

72. Hughes, K.A.; Sutherland, I.W.; Jones, M.V. Biofilm susceptibility to bacteriophage attack: The role of phage-borne polysaccharide depolymerase. Microbiology 1998, 144 Pt 11, 3039-3047. [CrossRef]

73. Dennehy, J.J.; Abedon, S.T. Adsorption: Phage acquisition of bacteria. In Bacteriophages: Biology, Technology, Therapy; Springer: Cham, Switzerland, 2021; pp. 93-117.

74. Rakhuba, D.; Kolomiets, E.; Dey, E.S.; Novik, G. Bacteriophage receptors, mechanisms of phage adsorption and penetration into host cell. Pol. J. Microbiol. 2010, 59, 145. [CrossRef]

75. Azeredo, J.; Sutherland, I.W. The use of phages for the removal of infectious biofilms. Curr. Pharm. Biotechnol. 2008, 9, 261-266. [CrossRef]

76. Abedon, S.T. Lysis from without. Bacteriophage 2011, 1, 46-49. [CrossRef]

77. Young, R.; Bläsi, U. Holins: Form and function in bacteriophage lysis. FEMS Microbiol. Rev. 1995, 17, 191-205. [CrossRef]

78. Wang, I.-N.; Smith, D.L.; Young, R. Holins: The protein clocks of bacteriophage infections. Annu. Rev. Microbiol. 2000, 54, 799-825. [CrossRef]

79. Kongari, R.; Rajaure, M.; Cahill, J.; Rasche, E.; Mijalis, E.; Berry, J.; Young, R. Phage spanins: Diversity, topological dynamics and gene convergence. BMC Bioinform. 2018, 19, 326. [CrossRef]

80. Delbruck, M. The growth of bacteriophage and lysis of the host. J. Gen. Physiol. 1940, 23, 643-660. [CrossRef]

81. Young, R. Bacteriophage lysis: Mechanism and regulation. Microbiol. Mol. Biol. Rev. 1992, 56, 430-481. [CrossRef]

82. Schmelcher, M.; Donovan, D.M.; Loessner, M.J. Bacteriophage endolysins as novel antimicrobials. Future Microbiol. 2012, 7, 1147-1171. [CrossRef] 
83. Cota-Robles, E.H. Electron microscopy of "lysis from within" of Escherichia coli by coliphage T2. J. Ultrastruct. Res. 1964, 11, 112-122. [CrossRef]

84. Yan, J.; Mao, J.; Xie, J. Bacteriophage polysaccharide depolymerases and biomedical applications. BioDrugs 2014, 28, 265-274. [CrossRef]

85. Drulis-Kawa, Z.; Majkowska-Skrobek, G.; Maciejewska, B.; Delattre, A.-S.; Lavigne, R. Learning from bacteriophages-advantages and limitations of phage and phage-encoded protein applications. Curr. Protein Pept. Sci. 2012, 13, 699-722. [CrossRef]

86. Kim, S.; Oh, D.-B.; Kang, H.A.; Kwon, O. Features and applications of bacterial sialidases. Appl. Microbiol. Biotechnol. 2011, 91, 1-15. [CrossRef]

87. Yadav, V.; Yadav, P.K.; Yadav, S.; Yadav, K. $\alpha$-L-Rhamnosidase: A review. Process Biochem. 2010, 45, 1226-1235. [CrossRef]

88. Murakami, H.; Kuramoto, T.; Mizutani, K.; Nakano, H.; Kitahata, S. Purification and some properties of a new levanase from Bacillus sp. No. 71. Biosci. Biotechnol. Biochem. 1992, 56, 608-613. [CrossRef] [PubMed]

89. Miasnikov, A.N. Characterization of a novel endo-levanase and its gene from Bacillus sp. L7. FEMS Microbiol. Lett. 1997, 154, 23-28. [CrossRef] [PubMed]

90. Beg, Q.; Kapoor, M.; Mahajan, L.; Hoondal, G. Microbial xylanases and their industrial applications: A review. Appl. Microbiol. Biotechnol. 2001, 56, 326-338. [CrossRef] [PubMed]

91. Juturu, V.; Wu, J.C. Microbial exo-xylanases: A mini review. Appl. Biochem. Biotechnol. 2014, 174, 81-92. [CrossRef] [PubMed]

92. Juturu, V.; Wu, J.C. Microbial xylanases: Engineering, production and industrial applications. Biotechnol. Adv. 2012, 30, 1219-1227. [CrossRef]

93. Kulkarni, N.; Shendye, A.; Rao, M. Molecular and biotechnological aspects of xylanases. FEMS Microbiol. Rev. 1999, 23, 411-456. [CrossRef]

94. Jiménez, E.R. Dextranase in sugar industry: A review. Sugar Tech. 2009, 11, 124-134. [CrossRef]

95. Jiménez, E.R. The dextranase along sugar-making industry. Biotecnol. Apl. 2005, 22, $20-27$.

96. Prokhorov, N.S.; Riccio, C.; Zdorovenko, E.L.; Shneider, M.M.; Browning, C.; Knirel, Y.A.; Leiman, P.G.; Letarov, A.V. Function of bacteriophage G7C esterase tailspike in host cell adsorption. Mol. Microbiol. 2017, 105, 385-398. [CrossRef]

97. Sutherland, I.W. Polysaccharide lyases. FEMS Microbiol. Rev. 1995, 16, 323-347. [CrossRef]

98. Michaud, P.; Da Costa, A.; Courtois, B.; Courtois, J. Polysaccharide lyases: Recent developments as biotechnological tools. Crit. Rev. Biotechnol. 2003, 23, 233-266. [CrossRef]

99. Singh, S.K.; Bharati, A.P.; Singh, N.; Pandey, P.; Joshi, P.; Singh, K.; Mitra, K.; Gayen, J.R.; Sarkar, J.; Akhtar, M.S. The prophageencoded hyaluronate lyase has broad substrate specificity and is regulated by the N-terminal domain. J. Biol. Chem. 2014, 289, 35225-35236. [CrossRef]

100. Cornelissen, A.; Ceyssens, P.J.; T’Syen, J.; Van Praet, H.; Noben, J.P.; Shaburova, O.V.; Krylov, V.N.; Volckaert, G.; Lavigne, R. The T7-related Pseudomonas putida phage phi15 displays virion-associated biofilm degradation properties. PLoS ONE 2011, 6, e18597. [CrossRef]

101. Cornelissen, A.; Ceyssens, P.-J.; Krylov, V.N.; Noben, J.-P.; Volckaert, G.; Lavigne, R. Identification of EPS-degrading activity within the tail spikes of the novel Pseudomonas putida phage AF. Virology 2012, 434, 251-256. [CrossRef]

102. Wong, T.Y.; Preston, L.A.; Schiller, N.L. Alginate lyase: Review of major sources and enzyme characteristics, structure-function analysis, biological roles, and applications. Annu. Rev. Microbiol. 2000, 54, 289-340. [CrossRef]

103. Kim, H.S.; Lee, C.-G.; Lee, E.Y. Alginate lyase: Structure, property, and application. Biotechnol. Bioprocess Eng. 2011, 16, 843. [CrossRef]

104. Scholl, D.; Rogers, S.; Adhya, S.; Merril, C.R. Bacteriophage K1-5 encodes two different tail fiber proteins, allowing it to infect and replicate on both K1 and K5 strains of Escherichia coli. J. Virol. 2001, 75, 2509-2515. [CrossRef]

105. Olszak, T.; Shneider, M.M.; Latka, A.; Maciejewska, B.; Browning, C.; Sycheva, L.V.; Cornelissen, A.; Danis-Wlodarczyk, K.; Senchenkova, S.N.; Shashkov, A.S.; et al. The O-specific polysaccharide lyase from the phage LKA1 tailspike reduces Pseudomonas virulence. Sci. Rep. 2017, 7, 16302. [CrossRef]

106. Drulis-Kawa, Z.; Majkowska-Skrobek, G.; Maciejewska, B. Bacteriophages and phage-derived proteins-application approaches. Curr. Med. Chem. 2015, 22, 1757-1773. [CrossRef]

107. Harper, D.R.; Parracho, H.M.; Walker, J.; Sharp, R.; Hughes, G.; Werthén, M.; Lehman, S.; Morales, S. Bacteriophages and biofilms. Antibiotics 2014, 3, 270-284. [CrossRef]

108. Sutherland, I.W.; Hughes, K.A.; Skillman, L.C.; Tait, K. The interaction of phage and biofilms. FEMS Microbiol. Lett. 2004, 232, 1-6. [CrossRef]

109. Santos, S.B.; Carvalho, C.M.; Sillankorva, S.; Nicolau, A.; Ferreira, E.C.; Azeredo, J. The use of antibiotics to improve phage detection and enumeration by the double-layer agar technique. BMC Microbiol. 2009, 9, 148. [CrossRef]

110. Fischer, D.; Eisenberg, D. Finding families for genomic ORFans. Bioinformatics 1999, 15, 759-762. [CrossRef]

111. Siew, N.; Fischer, D. Structural biology sheds light on the puzzle of genomic ORFans. J. Mol. Biol. 2004, 342, 369-373. [CrossRef]

112. Wagemans, J.; Blasdel, B.G.; Van den Bossche, A.; Uytterhoeven, B.; De Smet, J.; Paeshuyse, J.; Cenens, W.; Aertsen, A.; Uetz, P.; Delattre, A.S. Functional elucidation of antibacterial phage ORFans targeting Pseudomonas aeruginosa. Cell. Microbiol. 2014, 16, 1822-1835. [CrossRef] [PubMed]

113. Frost, L.S.; Leplae, R.; Summers, A.O.; Toussaint, A. Mobile genetic elements: The agents of open source evolution. Nat. Rev. Microbiol. 2005, 3, 722-732. [CrossRef] [PubMed] 
114. Li, H.-F.; Wang, X.-F.; Tang, H. Predicting bacteriophage enzymes and hydrolases by using combined features. Front. Bioeng. Biotechnol. 2020, 8, 183. [CrossRef] [PubMed]

115. Ding, H.; Yang, W.; Tang, H.; Feng, P.-M.; Huang, J.; Chen, W.; Lin, H. PHYPred: A tool for identifying bacteriophage enzymes and hydrolases. Virol. Sin. 2016, 31, 350-352. [CrossRef] [PubMed]

116. Manrique, P.; Dills, M.; Young, M.J. The human gut phage community and its implications for health and disease. Viruses 2017, 9 , 141. [CrossRef] [PubMed]

117. Mirzaei, M.K.; Maurice, C.F. Ménage à trois in the human gut: Interactions between host, bacteria and phages. Nat. Rev. Microbiol. 2017, 15, 397-408. [CrossRef] [PubMed]

118. Dahlman, S.; Avellaneda-Franco, L.; Barr, J.J. Phages to shape the gut microbiota? Curr. Opin. Biotechnol. 2021, 68, 89-95. [CrossRef] [PubMed]

119. Navarro, F.; Muniesa, M. Phages in the human body. Front. Microbiol. 2017, 8, 566. [CrossRef]

120. McCallum, K.L.; Laakso, D.H.; Whitfield, C. Use of a bacteriophage-encoded glycanase enzyme in the generation of lipopolysaccharide $\mathrm{O}$ side chain deficient mutants of Escherichia coli O9: K30 and Klebsiella O1: K20: Role of O and K antigens in resistance to complement-mediated serum killing. Can. J. Microbiol. 1989, 35, 994-999. [CrossRef]

121. Smith, H.W.; Huggins, M. Successful treatment of experimental Escherichia coli infections in mice using phage: Its general superiority over antibiotics. Microbiology 1982, 128, 307-318. [CrossRef]

122. Lin, H.; Paff, M.L.; Molineux, I.J.; Bull, J.J. Therapeutic application of phage capsule depolymerases against K1, K5, and K30 capsulated E. coli in mice. Front. Microbiol. 2017, 8, 2257. [CrossRef]

123. Gordillo Altamirano, F.; Forsyth, J.H.; Patwa, R.; Kostoulias, X.; Trim, M.; Subedi, D.; Archer, S.K.; Morris, F.C.; Oliveira, C.; Kielty, L.; et al. Bacteriophage-resistant Acinetobacter baumannii are resensitized to antimicrobials. Nat. Microbiol. 2021, 6, 157-161. [CrossRef]

124. Manzanares, P.; Vallés, S.; Ramòn, D.; Orejas, M. $\alpha$-L-Rhamnosidases: Old and new insights. In Industrial Enzymes; Springer: Dordrecht, The Netherlands, 2007; pp. 117-140.

125. Sieiro, C.; García-Fraga, B.; López-Seijas, J.; da Silva, A.F.; Villa, T.G. Microbial pectic enzymes in the food and wine industry. In Food Industrial Processes-Methods and Equipment; IntechOpen: Rijeka, Croatia, 2012.

126. Born, Y.; Fieseler, L.; Klumpp, J.; Eugster, M.R.; Zurfluh, K.; Duffy, B.; Loessner, M.J. The tail-associated depolymerase of Erwinia amylovora phage L1 mediates host cell adsorption and enzymatic capsule removal, which can enhance infection by other phage. Environ. Microbiol. 2014, 16, 2168-2180. [CrossRef]

127. Biziulevičius, G.A.; Biziulevičienè, G.; Kazlauskaitè, J. A list of enzyme preparations covered by the term enzybiotics should not be restricted to bacteriophage-encoded peptidoglycan hydrolases (lysins). J. Pharm. Pharmacol. 2008, 60, 531-532. [CrossRef]

128. Kim, W.-S.; Geider, K. Characterization of a viral EPS-depolymerase, a potential tool for control of fire blight. Phytopathology 2000, 90, 1263-1268. [CrossRef]

129. Scorpio, A.; Tobery, S.A.; Ribot, W.J.; Friedlander, A.M. Treatment of experimental anthrax with recombinant capsule depolymerase. Antimicrob. Agents Chemother. 2008, 52, 1014-1020. [CrossRef]

130. Gutierrez, D.; Briers, Y.; Rodriguez-Rubio, L.; Martinez, B.; Rodriguez, A.; Lavigne, R.; Garcia, P. Role of the Pre-neck appendage protein (Dpo7) from phage vB_SepiS-phiIPLA7 as an anti-biofilm agent in Staphylococcal Species. Front. Microbiol. 2015, 6, 1315. [CrossRef]

131. Oliveira, H.; Costa, A.R.; Ferreira, A.; Konstantinides, N.; Santos, S.B.; Boon, M.; Noben, J.P.; Lavigne, R.; Azeredo, J. Functional analysis and antivirulence properties of a new depolymerase from a myovirus that infects Acinetobacter baumannii capsule K45. J. Virol. 2019, 93, e01163-18. [CrossRef]

132. Majkowska-Skrobek, G.; Łatka, A.; Berisio, R.; Maciejewska, B.; Squeglia, F.; Romano, M.; Lavigne, R.; Struve, C.; Drulis-Kawa, Z. Capsule-targeting depolymerase, derived from Klebsiella KP36 phage, as a tool for the development of anti-virulent strategy. Viruses 2016, 8, 324. [CrossRef]

133. Mushtaq, N.; Redpath, M.B.; Luzio, J.P.; Taylor, P.W. Prevention and cure of systemic Escherichia coli K1 infection by modification of the bacterial phenotype. Antimicrob. Agents Chemother. 2004, 48, 1503-1508. [CrossRef]

134. Mushtaq, N.; Redpath, M.B.; Luzio, J.P.; Taylor, P.W. Treatment of experimental Escherichia coli infection with recombinant bacteriophage-derived capsule depolymerase. J. Antimicrob. Chemother. 2005, 56, 160-165. [CrossRef]

135. Bansal, S.; Soni, S.K.; Harjai, K.; Chhibber, S. Aeromonas punctata derived depolymerase that disrupts the integrity of Klebsiella pneumoniae capsule: Optimization of depolymerase production. J. Basic Microbiol. 2014, 54, 711-720. [CrossRef]

136. Kim, I.-G.; Lee, M.-S.; Jin, T.-E.; Hwang, B.-K.; Lee, J.-H.; Suh, S.-C.; Rhim, S.-L. Inhibitory effect of bacteriophage EPSdepolymerase on growth of Asian pear blight pathogen Erwinia pyrifoliae. J. Microbiol. Biotechnol. 2004, 14, 872-876.

137. Lu, T.K.; Collins, J.J. Dispersing biofilms with engineered enzymatic bacteriophage. Proc. Natl. Acad. Sci. USA 2007, 104, 11197-11202. [CrossRef]

138. Lin, H.; Paff, M.; Molineux, I.; Bull, J. Antibiotic therapy using phage depolymerases: Robustness across a range of conditions. Viruses 2018, 10, 622. [CrossRef]

139. Niemann, H.; Kwiatkowski, B.; Westphal, U.; Stirm, S. Klebsiella serotype 25 capsular polysaccharide: Primary structure and depolymerization by a bacteriophage-borne glycanase. J. Bacteriol. 1977, 130, 366-374. [CrossRef]

140. Altmann, F.; Christian, R.; Czerny, T.; Nimmich, W.; März, L. Bacteriophage-associated glycan hydrolases specific for Escherichia coli capsular serotype K12. Eur. J. Biochem. 1990, 189, 307-312. [CrossRef] 
141. Cheng, Q.; Fischetti, V.A. Mutagenesis of a bacteriophage lytic enzyme PlyGBS significantly increases its antibacterial activity against group B streptococci. Appl. Microbiol. Biotechnol. 2007, 74, 1284-1291. [CrossRef]

142. Pastagia, M.; Euler, C.; Chahales, P.; Fuentes-Duculan, J.; Krueger, J.G.; Fischetti, V.A. A novel chimeric lysin shows superiority to mupirocin for skin decolonization of methicillin-resistant and-sensitive Staphylococcus aureus strains. Antimicrob. Agents Chemother. 2011, 55, 738-744. [CrossRef]

143. Gilmer, D.B.; Schmitz, J.E.; Euler, C.W.; Fischetti, V.A. Novel bacteriophage lysin with broad lytic activity protects against mixed infection by Streptococcus pyogenes and methicillin-resistant Staphylococcus aureus. Antimicrob. Agents Chemother. 2013, 57, 2743-2750. [CrossRef]

144. Yoong, P.; Schuch, R.; Nelson, D.; Fischetti, V.A. PlyPH, a bacteriolytic enzyme with a broad pH range of activity and lytic action against Bacillus anthracis. J. Bacteriol. 2006, 188, 2711-2714. [CrossRef] [PubMed]

145. Chen, Y.; Li, X.; Wang, S.; Guan, L.; Li, X.; Hu, D.; Gao, D.; Song, J.; Chen, H.; Qian, P.; et al. A novel tail-associated O91-specific polysaccharide depolymerase from a podophage reveals lytic efficacy of shiga toxin-producing Escherichia coli. Appl. Environ. Microbiol. 2020, 86, e00145-20. [CrossRef] [PubMed]

146. Jado, I.; López, R.; García, E.; Fenoll, A.; Casal, J.; García, P. Phage lytic enzymes as therapy for antibiotic-resistant Streptococcus pneumoniae infection in a murine sepsis model. J. Antimicrob. Chemother. 2003, 52, 967-973. [CrossRef] [PubMed]

147. Gu, J.; Xu, W.; Lei, L.; Huang, J.; Feng, X.; Sun, C.; Du, C.; Zuo, J.; Li, Y.; Du, T. LysGH15, a novel bacteriophage lysin, protects a murine bacteremia model efficiently against lethal methicillin-resistant Staphylococcus aureus infection. J. Clin. Microbiol. 2011, 49, 111-117. [CrossRef]

148. Gupta, R.; Prasad, Y. P-27/HP endolysin as antibacterial agent for antibiotic resistant Staphylococcus aureus of human infections. Curr. Microbiol. 2011, 63, 39. [CrossRef]

149. K Chan, B.; T Abedon, S. Bacteriophages and their enzymes in biofilm control. Curr. Pharmaceut. Des. 2015, 21, 85-99. [CrossRef]

150. Waseh, S.; Hanifi-Moghaddam, P.; Coleman, R.; Masotti, M.; Ryan, S.; Foss, M.; MacKenzie, R.; Henry, M.; Szymanski, C.M.; Tanha, J. Orally administered P22 phage tailspike protein reduces Salmonella colonization in chickens: Prospects of a novel therapy against bacterial infections. PLoS ONE 2010, 5, e13904. [CrossRef]

151. Chen, Y.; Sun, E.; Yang, L.; Song, J.; Wu, B. Therapeutic application of bacteriophage PHB02 and its putative depolymerase against Pasteurella multocida capsular type A in mice. Front. Microbiol. 2018, 9, 1678. [CrossRef]

152. Wang, C.; Li, P.; Niu, W.; Yuan, X.; Liu, H.; Huang, Y.; An, X.; Fan, H.; Zhangxiang, L.; Mi, L.; et al. Protective and therapeutic application of the depolymerase derived from a novel KN1 genotype of Klebsiella pneumoniae bacteriophage in mice. Res. Microbiol. 2019, 170, 156-164. [CrossRef]

153. Pan, Y.-J.; Lin, T.-L.; Lin, Y.-T.; Su, P.-A.; Chen, C.-T.; Hsieh, P.-F.; Hsu, C.-R.; Chen, C.-C.; Hsieh, Y.-C.; Wang, J.-T. Identification of capsular types in carbapenem-resistant Klebsiella pneumoniae strains by wzc sequencing and implications for capsule depolymerase treatment. Antimicrob. Agents Chemother. 2015, 59, 1038-1047. [CrossRef]

154. Shahed-Al-Mahmud, M.; Roy, R.; Sugiokto, F.G.; Islam, M.N.; Lin, M.-D.; Lin, L.-C.; Lin, N.-T. Phage $\varphi$ AB6-borne depolymerase combats Acinetobacter baumannii biofilm formation and infection. Antibiotics 2021, 10, 279. [CrossRef]

155. Liu, Y.; Leung, S.S.Y.; Guo, Y.; Zhao, L.; Jiang, N.; Mi, L.; Li, P.; Wang, C.; Qin, Y.; Mi, Z.; et al. The capsule depolymerase Dpo48 rescues Galleria mellonella and mice from Acinetobacter baumannii systemic infections. Front. Microbiol. 2019, 10, 545. [CrossRef]

156. Oliveira, H.; Mendes, A.; Fraga, A.G.; Ferreira, A.; Pimenta, A.I.; Mil-Homens, D.; Fialho, A.M.; Pedrosa, J.; Azeredo, J. K2 capsule depolymerase is highly stable, is refractory to resistance, and protects larvae and mice from Acinetobacter baumannii sepsis. Appl. Environ. Microbiol. 2019, 85, e00934-00919. [CrossRef]

157. Jun, S.Y.; Jang, I.J.; Yoon, S.; Jang, K.; Yu, K.S.; Cho, J.Y.; Seong, M.W.; Jung, G.M.; Yoon, S.J.; Kang, S.H. Pharmacokinetics and tolerance of the phage endolysin-based candidate drug SAL200 after a single intravenous administration among healthy volunteers. Antimicrob. Agents Chemother. 2017, 61, e02629-16. [CrossRef]

158. Abdelrahman, F.; Easwaran, M.; Daramola, O.I.; Ragab, S.; Lynch, S.; Oduselu, T.J.; Khan, F.M.; Ayobami, A.; Adnan, F.; Torrents, E. Phage-encoded endolysins. Antibiotics 2021, 10, 124. [CrossRef]

159. Schmelcher, M.; Loessner, M.J. Bacteriophage endolysins-extending their application to tissues and the bloodstream. Curr. Opin. Biotechnol. 2021, 68, 51-59. [CrossRef]

160. Linden, S.B.; Alreja, A.B.; Nelson, D.C. Application of bacteriophage-derived endolysins to combat streptococcal disease: Current State and perspectives. Curr. Opin. Biotechnol. 2021, 68, 213-220. [CrossRef]

161. Nachimuthu, R.; Madurantakam Royam, M.; Manohar, P.; Leptihn, S. Application of bacteriophages and endolysins in aquaculture as a biocontrol measure. Biol. Control 2021, 160, 104678. [CrossRef]

162. Tišáková, L.; Godány, A. Bacteriophage endolysins and their use in biotechnological processes. J. Microbiol. Biotechnol. Food Sci. 2021, 2021, 164-170.

163. Lai, M.-J.; Lin, N.-T.; Hu, A.; Soo, P.-C.; Chen, L.-K.; Chen, L.-H.; Chang, K.-C. Antibacterial activity of Acinetobacter baumannii phage $\phi A B 2$ endolysin (LysAB2) against both gram-positive and gram-negative bacteria. Appl. Microbiol. Biotechnol. 2011, 90, 529-539. [CrossRef]

164. Jun, S.Y.; Jung, G.M.; Yoon, S.J.; Oh, M.-D.; Choi, Y.-J.; Lee, W.J.; Kong, J.-C.; Seol, J.G.; Kang, S.H. Antibacterial properties of a pre-formulated recombinant phage endolysin, SAL-1. Int. J. Antimicrob. Agents 2013, 41, 156-161. [CrossRef]

165. Huang, G.; Shen, X.; Gong, Y.; Dong, Z.; Zhao, X.; Shen, W.; Wang, J.; Hu, F.; Peng, Y. Antibacterial properties of Acinetobacter baumannii phage Abp1 endolysin (PlyAB1). BMC Infect. Dis. 2014, 14, 681. [CrossRef] 
166. Rodríguez-Rubio, L.; Chang, W.-L.; Gutiérrez, D.; Lavigne, R.; Martínez, B.; Rodríguez, A.; Govers, S.K.; Aertsen, A.; Hirl, C.; Biebl, M. 'Artilysation' of endolysin $\lambda$ Sa2lys strongly improves its enzymatic and antibacterial activity against streptococci. Sci. Rep. 2016, 6, 35382. [CrossRef]

167. Skorynina, A.V.; Piligrimova, E.G.; Kazantseva, O.A.; Kulyabin, V.A.; Baicher, S.D.; Ryabova, N.A.; Shadrin, A.M. Bacillus-infecting bacteriophage Izhevsk harbors thermostable endolysin with broad range specificity. PLoS ONE 2020, 15, e0242657. [CrossRef]

168. Letrado, P.; Corsini, B.; Díez-Martínez, R.; Bustamante, N.; Yuste, J.E.; García, P. Bactericidal synergism between antibiotics and phage endolysin Cpl-711 to kill multidrug-resistant Pneumococcus. Future Microbiol. 2018, 13, 1215-1223. [CrossRef]

169. Shen, Y.; Barros, M.; Vennemann, T.; Gallagher, D.T.; Yin, Y.; Linden, S.B.; Heselpoth, R.D.; Spencer, D.J.; Donovan, D.M.; Moult, J. A bacteriophage endolysin that eliminates intracellular streptococci. Elife 2016, 5, e13152. [CrossRef]

170. Loessner, M.J. Bacteriophage endolysins-current state of research and applications. Curr. Opin. Microbiol. 2005, 8, 480-487. [CrossRef]

171. Fischetti, V.A. Bacteriophage endolysins: A novel anti-infective to control Gram-positive pathogens. Int. J. Med. Microbiol. 2010, 300, 357-362. [CrossRef] [PubMed]

172. Schmelcher, M.; Loessner, M.J. Bacteriophage endolysins: Applications for food safety. Curr. Opin. Biotechnol. 2016, 37, 76-87. [CrossRef] [PubMed]

173. Kong, M.; Ryu, S. Bacteriophage PBC1 and its endolysin as an antimicrobial agent against Bacillus cereus. Appl. Environ. Microbiol. 2015, 81, 2274-2283. [CrossRef] [PubMed]

174. Chang, Y. Bacteriophage-derived endolysins applied as potent biocontrol agents to enhance food safety. Microorganisms 2020, 8 , 724. [CrossRef]

175. Lai, W.C.B.; Chen, X.; Ho, M.K.Y.; Xia, J.; Leung, S.S.Y. Bacteriophage-derived endolysins to target gram-negative bacteria. Int. J. Pharm. 2020, 589, 119833. [CrossRef]

176. Caflisch, K.M.; Suh, G.A.; Patel, R. Biological challenges of phage therapy and proposed solutions: A literature review. Expert Rev. Anti-Infect. Ther. 2019, 17, 1011-1041. [CrossRef]

177. Broendum, S.S.; Buckle, A.M.; McGowan, S. Catalytic diversity and cell wall binding repeats in the phage-encoded endolysins. Mol. Microbiol. 2018, 110, 879-896. [CrossRef]

178. Dunne, M.; Mertens, H.D.; Garefalaki, V.; Jeffries, C.M.; Thompson, A.; Lemke, E.A.; Svergun, D.I.; Mayer, M.J.; Narbad, A.; Meijers, R. The CD27L and CTP1L endolysins targeting Clostridia contain a built-in trigger and release factor. PLoS Pathog. 2014, 10, e1004228. [CrossRef]

179. Donovan, D.M.; Foster-Frey, J.; Dong, S.; Rousseau, G.M.; Moineau, S.; Pritchard, D.G. The cell lysis activity of the Streptococcus agalactiae bacteriophage B30 endolysin relies on the cysteine, histidine-dependent amidohydrolase/peptidase domain. Appl. Environ. Microbiol. 2006, 72, 5108-5112. [CrossRef]

180. Park, S.; Jun, S.Y.; Kim, C.-H.; Jung, G.M.; Son, J.S.; Jeong, S.T.; Yoon, S.J.; Lee, S.Y.; Kang, S.H. Characterisation of the antibacterial properties of the recombinant phage endolysins AP50-31 and LysB4 as potent bactericidal agents against Bacillus anthracis. Sci. Rep. 2018, 8, 18. [CrossRef]

181. Yang, D.; Chen, Y.; Sun, E.; Hua, L.; Peng, Z.; Wu, B. Characterization of a lytic bacteriophage vB_EfaS_PHB08 harboring endolysin Lys08 against Enterococcus faecalis biofilms. Microorganisms 2020, 8, 1332. [CrossRef]

182. Lim, J.-A.; Shin, H.; Kang, D.-H.; Ryu, S. Characterization of endolysin from a Salmonella Typhimurium-infecting bacteriophage SPN1S. Res. Microbiol. 2012, 163, 233-241. [CrossRef]

183. Gong, P.; Cheng, M.; Li, X.; Jiang, H.; Yu, C.; Kahaer, N.; Li, J.; Zhang, L.; Xia, F.; Hu, L. Characterization of Enterococcus faecium bacteriophage IME-EFm5 and its endolysin LysEFm5. Virology 2016, 492, 11-20. [CrossRef]

184. Walmagh, M.; Boczkowska, B.; Grymonprez, B.; Briers, Y.; Drulis-Kawa, Z.; Lavigne, R. Characterization of five novel endolysins from Gram-negative infecting bacteriophages. Appl. Microbiol. Biotechnol. 2013, 97, 4369-4375. [CrossRef] [PubMed]

185. Silva, M.D.; Oliveira, H.; Faustino, A.; Sillankorva, S. Characterization of MSlys, the endolysin of Streptococcus pneumoniae phage MS1. Biotechnol. Rep. 2020, 28, e00547. [CrossRef] [PubMed]

186. Son, B.; Kong, M.; Lee, Y.; Ryu, S. Development of a novel chimeric endolysin, Lys109 with enhanced lytic activity against Staphylococcus aureus. Front. Microbiol. 2021, 11, 3490. [CrossRef] [PubMed]

187. Rodríguez-Rubio, L.; Gerstmans, H.; Thorpe, S.; Mesnage, S.; Lavigne, R.; Briers, Y. DUF3380 domain from a Salmonella phage endolysin shows potent N-acetylmuramidase activity. Appl. Environ. Microbiol. 2016, 82, 4975-4981. [CrossRef]

188. Gutierrez, D.; Ruas-Madiedo, P.; Martínez, B.; Rodríguez, A.; García, P. Effective removal of staphylococcal biofilms by the endolysin LysH5. PLoS ONE 2014, 9, e107307. [CrossRef]

189. De Wit, J.; Totte, J.E.; van Mierlo, M.M.; van Veldhuizen, J.; van Doorn, M.B.; Schuren, F.H.; Willemsen, S.P.; Pardo, L.M.; Pasmans, S. Endolysin treatment against Staphylococcus aureus in adults with atopic dermatitis: A randomized controlled trial. J. Allergy Clin. Immunol. 2019, 144, 860-863. [CrossRef]

190. Gondil, V.S.; Harjai, K.; Chhibber, S. Endolysins as emerging alternative therapeutic agents to counter drug-resistant infections. Int. J. Antimicrob. Agents 2020, 55, 105844. [CrossRef]

191. Briers, Y.; Walmagh, M.; Van Puyenbroeck, V.; Cornelissen, A.; Cenens, W.; Aertsen, A.; Oliveira, H.; Azeredo, J.; Verween, G.; Pirnay, J.-P. Engineered endolysin-based “Artilysins" to combat multidrug-resistant gram-negative pathogens. MBio 2014, 5, e01379-14. [CrossRef] 
192. Thummeepak, R.; Kitti, T.; Kunthalert, D.; Sitthisak, S. Enhanced antibacterial activity of Acinetobacter baumannii bacteriophage ØABP-01 endolysin (LysABP-01) in combination with colistin. Front. Microbiol. 2016, 7, 1402. [CrossRef]

193. García, P.; Rodríguez, L.; Rodríguez, A.; Martínez, B. Food biopreservation: Promising strategies using bacteriocins, bacteriophages and endolysins. Trends Food Sci. Technol. 2010, 21, 373-382. [CrossRef]

194. Gerstmans, H.; Rodríguez-Rubio, L.; Lavigne, R.; Briers, Y. From endolysins to Artilysin®s: Novel enzyme-based approaches to kill drug-resistant bacteria. Biochem. Soc. Trans. 2016, 44, 123-128. [CrossRef]

195. Morita, M.; Tanji, Y.; Orito, Y.; Mizoguchi, K.; Soejima, A.; Unno, H. Functional analysis of antibacterial activity of Bacillus amyloliquefaciens phage endolysin against Gram-negative bacteria. FEBS Lett. 2001, 500, 56-59. [CrossRef]

196. Briers, Y.; Schmelcher, M.; Loessner, M.J.; Hendrix, J.; Engelborghs, Y.; Volckaert, G.; Lavigne, R. The high-affinity peptidoglycan binding domain of Pseudomonas phage endolysin KZ144. Biochem. Biophys. Res. Commun. 2009, 383, 187-191. [CrossRef]

197. Peng, S.-Y.; You, R.-I.; Lai, M.-J.; Lin, N.-T.; Chen, L.-K.; Chang, K.-C. Highly potent antimicrobial modified peptides derived from the Acinetobacter baumannii phage endolysin LysAB2. Sci. Rep. 2017, 7, 11477. [CrossRef]

198. Blasco, L.; Ambroa, A.; Trastoy, R.; Bleriot, I.; Moscoso, M.; Fernández-Garcia, L.; Perez-Nadales, E.; Fernández-Cuenca, F.; Torre-Cisneros, J.; Oteo-Iglesias, J.; et al. In vitro and in vivo efficacy of combinations of colistin and different endolysins against clinical strains of multi-drug resistant pathogens. Sci. Rep. 2020, 10, 7163. [CrossRef]

199. Singh, P.K.; Donovan, D.M.; Kumar, A. Intravitreal injection of the chimeric phage endolysin Ply187 protects mice from Staphylococcus aureus endophthalmitis. Antimicrob. Agents Chemother. 2014, 58, 4621-4629. [CrossRef]

200. Briers, Y.; Peeters, L.M.; Volckaert, G.; Lavigne, R. The lysis cassette of bacteriophage $\phi K M V$ encodes a signal-arrest-release endolysin and a pinholin. Bacteriophage 2011, 1, 25-30. [CrossRef]

201. Kim, S.; Jin, J.-S.; Choi, Y.-J.; Kim, J. LysSAP26, a new recombinant phage endolysin with a broad spectrum antibacterial activity. Viruses 2020, 12, 1340. [CrossRef]

202. Obeso, J.M.; Martínez, B.; Rodríguez, A.; García, P. Lytic activity of the recombinant staphylococcal bacteriophage $\Phi H 5$ endolysin active against Staphylococcus aureus in milk. Int. J. Food Microbiol. 2008, 128, 212-218. [CrossRef]

203. Briers, Y.; Volckaert, G.; Cornelissen, A.; Lagaert, S.; Michiels, C.W.; Hertveldt, K.; Lavigne, R. Muralytic activity and modular structure of the endolysins of Pseudomonas aeruginosa bacteriophages $\varphi$ KZ and EL. Mol. Microbiol. 2007, 65, 1334-1344. [CrossRef]

204. Kong, M.; Sim, J.; Kang, T.; Nguyen, H.H.; Park, H.K.; Chung, B.H.; Ryu, S. A novel and highly specific phage endolysin cell wall binding domain for detection of Bacillus cereus. Eur. Biophys. J. 2015, 44, 437-446. [CrossRef]

205. Guo, M.; Feng, C.; Ren, J.; Zhuang, X.; Zhang, Y.; Zhu, Y.; Dong, K.; He, P.; Guo, X.; Qin, J. A novel antimicrobial endolysin, LysPA26, against Pseudomonas aeruginosa. Front. Microbiol. 2017, 8, 293. [CrossRef]

206. Legotsky, S.A.; Vlasova, K.Y.; Priyma, A.D.; Shneider, M.M.; Pugachev, V.G.; Totmenina, O.D.; Kabanov, A.V.; Miroshnikov, K.A.; Klyachko, N.L. Peptidoglycan degrading activity of the broad-range Salmonella bacteriophage S-394 recombinant endolysin. Biochimie 2014, 107, 293-299. [CrossRef]

207. Young, R. Phage lysis: Three steps, three choices, one outcome. J. Microbiol. 2014, 52, 243-258. [CrossRef]

208. Shen, Y.; Köller, T.; Kreikemeyer, B.; Nelson, D.C. Rapid degradation of Streptococcus pyogenes biofilms by PlyC, a bacteriophageencoded endolysin. J. Antimicrob. Chemother. 2013, 68, 1818-1824. [CrossRef]

209. Kashani, H.H.; Schmelcher, M.; Sabzalipoor, H.; Hosseini, E.S.; Moniri, R. Recombinant endolysins as potential therapeutics against antibiotic-resistant Staphylococcus aureus: Current status of research and novel delivery strategies. Clin. Microbiol. Rev. 2018, 31, e00071-17.

210. Khatibi, P.A.; Roach, D.R.; Donovan, D.M.; Hughes, S.R.; Bischoff, K.M. Saccharomyces cerevisiae expressing bacteriophage endolysins reduce Lactobacillus contamination during fermentation. Biotechnol. Biofuels 2014, 7, 104. [CrossRef]

211. Oliveira, H.; Vilas Boas, D.; Mesnage, S.; Kluskens, L.D.; Lavigne, R.; Sillankorva, S.; Secundo, F.; Azeredo, J. Structural and enzymatic characterization of ABgp46, a novel phage endolysin with broad anti-gram-negative bacterial activity. Front. Microbiol. 2016, 7, 208. [CrossRef]

212. Totté, J.E.; van Doorn, M.B.; Pasmans, S.G. Successful treatment of chronic Staphylococcus aureus-related dermatoses with the topical endolysin Staphefekt SA. 100: A report of 3 cases. Case Rep. Dermatol. 2017, 9, 19-25. [CrossRef]

213. Schmelcher, M.; Powell, A.M.; Camp, M.J.; Pohl, C.S.; Donovan, D.M. Synergistic streptococcal phage $\lambda$ SA2 and B30 endolysins kill streptococci in cow milk and in a mouse model of mastitis. Appl. Microbiol. Biotechnol. 2015, 99, 8475-8486. [CrossRef]

214. García, P.; Martínez, B.; Rodríguez, L.; Rodríguez, A. Synergy between the phage endolysin LysH5 and nisin to kill Staphylococcus aureus in pasteurized milk. Int. J. Food Microbiol. 2010, 141, 151-155. [CrossRef] [PubMed]

215. Gerstmans, H.; Criel, B.; Briers, Y. Synthetic biology of modular endolysins. Biotechnol. Adv. 2018, 36, 624-640. [CrossRef] [PubMed]

216. Oliveira, H.; Thiagarajan, V.; Walmagh, M.; Sillankorva, S.; Lavigne, R.; Neves-Petersen, M.T.; Kluskens, L.D.; Azeredo, J. A thermostable Salmonella phage endolysin, Lys68, with broad bactericidal properties against gram-negative pathogens in presence of weak acids. PLoS ONE 2014, 9, e108376. [CrossRef] [PubMed]

217. Briers, Y.; Walmagh, M.; Lavigne, R. Use of bacteriophage endolysin EL188 and outer membrane permeabilizers against Pseudomonas aeruginosa. J. Appl. Microbiol. 2011, 110, 778-785. [CrossRef] [PubMed]

218. Rodríguez-Rubio, L.; Martínez, B.; Rodríguez, A.; Donovan, D.M.; García, P. Enhanced staphylolytic activity of the Staphylococcus aureus bacteriophage vB_SauS-phiIPLA88 HydH5 virion-associated peptidoglycan hydrolase: Fusions, deletions, and synergy with LysH5. Appl. Environ. Microbiol. 2012, 78, 2241-2248. [CrossRef] [PubMed] 
219. King, H.; Ajay Castro, S.; Pohane, A.A.; Scholte, C.M.; Fischetti, V.A.; Korotkova, N.; Nelson, D.C.; Dorfmueller, H.C. Molecular basis for recognition of the group A carbohydrate backbone by the PlyC streptococcal bacteriophage endolysin. Biochem. J. 2021, 478, 2385-2397. [CrossRef] [PubMed]

220. Resch, G.; Moreillon, P.; Fischetti, V.A. PEGylating a bacteriophage endolysin inhibits its bactericidal activity. AMB Express 2011, 1, 29. [CrossRef]

221. Schuch, R.; Pelzek, A.J.; Nelson, D.C.; Fischetti, V.A. The PlyB endolysin of bacteriophage vB_BanS_Bcp1 exhibits broad-spectrum bactericidal activity against Bacillus cereus sensu lato isolates. Appl. Environ. Microbiol. 2019, 85, e00003-19. [CrossRef]

222. Loeffler, J.M.; Nelson, D.; Fischetti, V.A. Rapid killing of Streptococcus pneumoniae with a bacteriophage cell wall hydrolase. Science 2001, 294, 2170-2172. [CrossRef]

223. Linden, S.B.; Zhang, H.; Heselpoth, R.D.; Shen, Y.; Schmelcher, M.; Eichenseher, F.; Nelson, D.C. Biochemical and biophysical characterization of PlyGRCS, a bacteriophage endolysin active against methicillin-resistant Staphylococcus aureus. Appl. Microbiol. Biotechnol. 2015, 99, 741-752. [CrossRef]

224. Shang, X.; Nelson, D.C. Contributions of net charge on the PlyC endolysin CHAP domain. Antibiotics 2019, 8, 70. [CrossRef]

225. Linden, S.B.; Scholte, C.M.; Vander Elst, N.; Moyes, K.M.; Nelson, D.C. Development of the PlyC endolysin as a bovine mastitis therapeutic for lactating dairy cows. In Proceedings of the 100th Annual conference of Research Workers in Animal Diseases (CRWAD 2019), Chicago, IL, USA, 2-5 November 2019.

226. Heselpoth, R.D.; Yin, Y.; Moult, J.; Nelson, D.C. Increasing the stability of the bacteriophage endolysin PlyC using rationale-based FoldX computational modeling. Protein Eng. Des. Sel. 2015, 28, 85-92. [CrossRef]

227. Linden, S.B.; Vander Elst, N.; Nelson, D.C. The PlySs9 endolysin contains unique catalytic domains and is a potential therapeutic against Streptococcus suis. In Proceedings of the 100th Annual conference of Research Workers in Animal Diseases (CRWAD 2019), Chicago, IL, USA, 2-5 November 2019.

228. Heselpoth, R.D.; Owens, J.M.; Nelson, D.C. Quantitative analysis of the thermal stability of the gamma phage endolysin PlyG: A biophysical and kinetic approach to assaying therapeutic potential. Virology 2015, 477, 125-132. [CrossRef]

229. Scholte, C.; Nelson, D.; Garcia, M.; Linden, S.; Elsasser, T.; Kahl, S.; Qu, Y.; Moyes, K. Recombinant bacteriophage endolysin PlyC is nontoxic and does not alter blood neutrophil oxidative response in lactating dairy cows. J. Dairy Sci. 2018, 101, 6419-6423. [CrossRef]

230. Harhala, M.; Nelson, D.C.; Miernikiewicz, P.; Heselpoth, R.D.; Brzezicka, B.; Majewska, J.; Linden, S.B.; Shang, X.; Szymczak, A.; Lecion, D. Safety studies of pneumococcal endolysins Cpl-1 and Pal. Viruses 2018, 10, 638. [CrossRef]

231. Jasim, H.N.; Hafidh, R.R.; Abdulamir, A.S. Formation of therapeutic phage cocktail and endolysin to highly multi-drug resistant Acinetobacter baumannii: In vitro and in vivo study. Iran. J. Basic Med. Sci. 2018, 21, 1100.

232. Basit, A.; Qadir, S.; Qureshi, S.; Rehman, S.U. Cloning and expression analysis of fused holin-endolysin from RL bacteriophage; Exhibits broad activity against multi drug resistant pathogens. Enzym. Microb. Technol. 2021, 149, 109846. [CrossRef]

233. Donovan, D.; Becker, S.; Dong, S.; Baker, J.; Foster-Frey, J.; Pritchard, D. Peptidoglycan hydrolase enzyme fusions for treating multi-drug resistant pathogens. Biotech. Int. 2009, 6-10.

234. Ali, M.R.; Abdulamir, A.S.; Kadhim, S.R. Extraction, purification and therapeutic use of bacteriophage endolysin against multi-drug resistant Staphylococcus aureus: In-vivo and in-vitro study. J. Contemp. Med. Sci. 2018, 4.

235. Haddad Kashani, H.; Fahimi, H.; Dasteh Goli, Y.; Moniri, R. A novel chimeric endolysin with antibacterial activity against methicillin-resistant Staphylococcus aureus. Front. Cell. Infect. Microbiol. 2017, 7, 290. [CrossRef]

236. Khan, F.M.; Gondil, V.S.; Li, C.; Jiang, M.; Li, J.; Yu, J.; Wei, H.; Yang, H. A novel Acinetobacter baumannii bacteriophage endolysin LysAB54 with high antibacterial activity against multiple Gram-negative microbes. Front. Cell. Infect. Microbiol. 2021, 11, 70. [CrossRef]

237. Mayer, M.J.; Garefalaki, V.; Spoerl, R.; Narbad, A.; Meijers, R. Structure-based modification of a Clostridium difficile-targeting endolysin affects activity and host range. J. Bacteriol. 2011, 193, 5477-5486. [CrossRef]

238. Schleimer, N.; Kaspar, U.; Knaack, D.; von Eiff, C.; Molinaro, S.; Grallert, H.; Idelevich, E.A.; Becker, K. In vitro activity of the bacteriophage endolysin HY-133 against Staphylococcus aureus small-colony variants and their corresponding wild types. Int. J. Mol. Sci. 2019, 20, 716. [CrossRef]

239. Knaack, D.; Idelevich, E.A.; Schleimer, N.; Molinaro, S.; Kriegeskorte, A.; Peters, G.; Becker, K. Bactericidal activity of bacteriophage endolysin HY-133 against Staphylococcus aureus in comparison to other antibiotics as determined by minimum bactericidal concentrations and time-kill analysis. Diagn. Microbiol. Infect. Dis. 2019, 93, 362-368. [CrossRef]

240. Lim, J.-A.; Shin, H.; Heu, S.; Ryu, S. Exogenous lytic activity of SPN9CC endolysin against gram-negative bacteria. J. Microbiol. Biotechnol. 2014, 24, 803-811. [CrossRef]

241. Zhang, H.; Buttaro, B.A.; Fouts, D.E.; Sanjari, S.; Evans, B.S.; Stevens, R.H. Bacteriophage $\varphi$ Ef11 ORF28 endolysin, a multifunctional lytic enzyme with properties distinct from all other identified Enterococcus faecalis phage endolysins. Appl. Environ. Microbiol. 2019, 85, e00555-00519. [CrossRef]

242. Yoong, P.; Schuch, R.; Nelson, D.; Fischetti, V.A. Identification of a broadly active phage lytic enzyme with lethal activity against antibiotic-resistant Enterococcus faecalis and Enterococcus faecium. J. Bacteriol. 2004, 186, 4808-4812. [CrossRef]

243. Rahimzadeh, G.; Gill, P.; Rezai, M.S. Endolysins of bacteriophages as an anti-methicillin resistant staphylococcus aureus infection in children: A narrative review. J. Pediatr. Rev. 2018, 6, 36-43. [CrossRef] 
244. Swift, S.M.; Reid, K.P.; Donovan, D.M.; Ramsay, T.G. Thermophile lytic enzyme fusion proteins that target Clostridium perfringens. Antibiotics 2019, 8, 214. [CrossRef]

245. Muharram, M.M.; Abulhamd, A.T.; Aldawsari, M.F.; Alqarni, M.H.; Labrou, N.E. Development of Staphylococcus enzybiotics: The Ph28 gene of Staphylococcus epidermidis phage PH15 is a two-domain endolysin. Antibiotics 2020, 9, 148. [CrossRef]

246. Domenech, M.; García, E.; Moscoso, M. In vitro destruction of Streptococcus pneumoniae biofilms with bacterial and phage peptidoglycan hydrolases. Antimicrob. Agents Chemother. 2011, 55, 4144-4148. [CrossRef]

247. Landlinger, C.; Tisakova, L.; Oberbauer, V.; Schwebs, T.; Muhammad, A.; Latka, A.; Van Simaey, L.; Vaneechoutte, M.; Guschin, A.; Resch, G. Engineered phage endolysin eliminates Gardnerella biofilm without damaging beneficial bacteria in bacterial vaginosis ex vivo. Pathogens 2021, 10, 54. [CrossRef] [PubMed]

248. Pennone, V.; Sanz-Gaitero, M.; O'connor, P.; Coffey, A.; Jordan, K.; van Raaij, M.J.; McAuliffe, O. Inhibition of L. monocytogenes biofilm formation by the amidase domain of the phage vB_LmoS_293 endolysin. Viruses 2019, 11, 722. [CrossRef] [PubMed]

249. Lu, Y.; Wang, Y.; Wang, J.; Zhao, Y.; Zhong, Q.; Li, G.; Fu, Z.; Lu, S. Phage endolysin LysP108 showed promising antibacterial potential against methicillin-resistant Staphylococcus aureus. Front. Cell. Infect. Microbiol. 2021, 11, 298. [CrossRef] [PubMed]

250. Zhang, Y.; Huang, H.-H.; Duc, H.M.; Masuda, Y.; Honjoh, K.-i.; Miyamoto, T. Endolysin LysSTG2: Characterization and application to control Salmonella Typhimurium biofilm alone and in combination with slightly acidic hypochlorous water. Food Microbiol. 2021, 98, 103791. [CrossRef]

251. López, R.; García, E.; García, P.; García, J.L. The pneumococcal cell wall degrading enzymes: A modular design to create new lysins? Microb. Drug Resist. 1997, 3, 199-211. [CrossRef]

252. Briers, Y.; Walmagh, M.; Grymonprez, B.; Biebl, M.; Pirnay, J.-P.; Defraine, V.; Michiels, J.; Cenens, W.; Aertsen, A.; Miller, S. Art-175 is a highly efficient antibacterial against multidrug-resistant strains and persisters of Pseudomonas aeruginosa. Antimicrob. Agents Chemother. 2014, 58, 3774-3784. [CrossRef]

253. Defraine, V.; Schuermans, J.; Grymonprez, B.; Govers, S.K.; Aertsen, A.; Fauvart, M.; Michiels, J.; Lavigne, R.; Briers, Y. Efficacy of artilysin Art-175 against resistant and persistent Acinetobacter baumannii. Antimicrob. Agents Chemother. 2016, 60, 3480-3488. [CrossRef]

254. Theuretzbacher, U.; Piddock, L.J. Non-traditional antibacterial therapeutic options and challenges. Cell Host Microbe 2019, 26, 61-72. [CrossRef]

255. Rashel, M.; Uchiyama, J.; Ujihara, T.; Uehara, Y.; Kuramoto, S.; Sugihara, S.; Yagyu, K.-I.; Muraoka, A.; Sugai, M.; Hiramatsu, K. Efficient elimination of multidrug-resistant Staphylococcus aureus by cloned lysin derived from bacteriophage $\phi$ MR11. J. Infect. Dis. 2007, 196, 1237-1247. [CrossRef]

256. Kim, N.-H.; Park, W.B.; Cho, J.E.; Choi, Y.J.; Choi, S.J.; Jun, S.Y.; Kang, C.K.; Song, K.-H.; Choe, P.G.; Bang, J.-H. Effects of phage endolysin SAL200 combined with antibiotics on Staphylococcus aureus infection. Antimicrob. Agents Chemother. 2018, 62, e00731-18. [CrossRef]

257. Becker, S.C.; Foster-Frey, J.; Donovan, D.M. The phage K lytic enzyme LysK and lysostaphin act synergistically to kill MRSA. FEMS Microbiol. Lett. 2008, 287, 185-191. [CrossRef]

258. Schmelcher, M.; Powell, A.M.; Becker, S.C.; Camp, M.J.; Donovan, D.M. Chimeric phage lysins act synergistically with lysostaphin to kill mastitis-causing Staphylococcus aureus in murine mammary glands. Appl. Environ. Microbiol. 2012, 78, 2297-2305. [CrossRef]

259. Loeffler, J.; Fischetti, V. Synergistic lethal effect of a combination of phage lytic enzymes with different activities on penicillinsensitive and-resistant Streptococcus pneumoniae strains. Antimicrob. Agents Chemother. 2003, 47, 375-377. [CrossRef]

260. Djurkovic, S.; Loeffler, J.M.; Fischetti, V.A. Synergistic killing of Streptococcus pneumoniae with the bacteriophage lytic enzyme Cpl-1 and penicillin or gentamicin depends on the level of penicillin resistance. Antimicrob. Agents Chemother. 2005, 49, 1225-1228. [CrossRef]

261. Daniel, A.; Euler, C.; Collin, M.; Chahales, P.; Gorelick, K.J.; Fischetti, V.A. Synergism between a novel chimeric lysin and oxacillin protects against infection by methicillin-resistant Staphylococcus aureus. Antimicrob. Agents Chemother. 2010, 54, 1603-1612. [CrossRef]

262. Vouillamoz, J.; Entenza, J.M.; Giddey, M.; Fischetti, V.A.; Moreillon, P.; Resch, G. Bactericidal synergism between daptomycin and the phage lysin Cpl-1 in a mouse model of pneumococcal bacteraemia. Int. J. Antimicrob. Agents 2013, 42, 416-421. [CrossRef]

263. Park, D.-W.; Park, J.-H. Characterization of Endolysin LysECP26 Derived from rV5-like Phage vB_EcoM-ECP26 for Inactivation of Escherichia coli O157: H7. J. Microbiol. Biotechnol. 2020, 30, 1552-1558. [CrossRef]

264. Entenza, J.; Loeffler, J.; Grandgirard, D.; Fischetti, V.; Moreillon, P. Therapeutic effects of bacteriophage Cpl-1 lysin against Streptococcus pneumoniae endocarditis in rats. Antimicrob. Agents Chemother. 2005, 49, 4789-4792. [CrossRef]

265. Witzenrath, M.; Schmeck, B.; Doehn, J.M.; Tschernig, T.; Zahlten, J.; Loeffler, J.M.; Zemlin, M.; Müller, H.; Gutbier, B.; Schütte, H. Systemic use of the endolysin Cpl-1 rescues mice with fatal pneumococcal pneumonia. Crit. Care Med. 2009, 37, 642-649. [CrossRef]

266. Cassino, C.; Murphy, M.; Boyle, J.; Rotolo, J.; Wittekind, M. Results of the first in human study of lysin CF-301 evaluating the safety, tolerability and pharmacokinetic profile in healthy volunteers. In Proceedings of the 26th European Congress of Clinical Microbiology and Infectious Diseases, Amsterdam, The Netherlands, 8-11 April 2016; pp. 151-152.

267. Jandourek, A.; Boyle, J.; Cassino, C.; Wittekind, M.; Kirby, H. Long term immunology results of a phase 1 placebo controlled dose escalating study to examine the safety of CF-301 in human volunteers. In Proceedings of the 27th ECCMID, Vienna, Austria, 22 April 2017; pp. 22-25. 
268. Jandourek, A.; Boyle, J.; Murphy, G.; Cassino, C. Inflammatory markers in a phase 1 placebo controlled dose escalating study of intravenous doses of CF-301 in human subjects. In Proceedings of the ASM Microbe, New Orleans, LA, USA, 2 June $2017 ;$ p. 2.

269. Ghahramani, P.; Khariton, T.; Jones, S.; Murphy, J.; Boyle, G.; Jandourek, A.; Cassino, C. Population pharmacokineticpharmacodynamic assessment of cardiac safety endpoints for CF-301, a first-in-class antibacterial lysin. In Proceedings of the ASM Microbe, New Orleans, LA, USA, 3 June 2017.

270. Rotolo, J.A.; Ramirez, R.A.; Schuch, R.; Machacek, M.; Khariton, T.; Ghahramani, P.; Wittekind, M. PK-PD driver of efficacy for CF-301, a novel anti-staphylococcal lysin: Implications for human target dose. In Proceedings of the ASM Microbe, Boston, MA, USA, 18 June 2016; pp. 16-20.

271. Jun, S.Y.; Jung, G.M.; Yoon, S.J.; Choi, Y.-J.; Koh, W.S.; Moon, K.S.; Kang, S.H. Preclinical safety evaluation of intravenously administered SAL200 containing the recombinant phage endolysin SAL-1 as a pharmaceutical ingredient. Antimicrob. Agents Chemother. 2014, 58, 2084-2088. [CrossRef]

272. Jun, S.Y.; Jung, G.M.; Yoon, S.J.; Youm, S.Y.; Han, H.Y.; Lee, J.H.; Kang, S.H. Pharmacokinetics of the phage endolysin-based candidate drug SAL 200 in monkeys and its appropriate intravenous dosing period. Clin. Exp. Pharmacol. Physiol. 2016, 43, 1013-1016. [CrossRef]

273. Roach, D.R.; Donovan, D.M. Antimicrobial bacteriophage-derived proteins and therapeutic applications. Bacteriophage 2015, 5, e1062590. [CrossRef] [PubMed]

274. Tamai, E.; Yoshida, H.; Sekiya, H.; Nariya, H.; Miyata, S.; Okabe, A.; Kuwahara, T.; Maki, J.; Kamitori, S. X-ray structure of a novel endolysin encoded by episomal phage phiSM 101 of $C$ lostridium perfringens. Mol. Microbiol. 2014, 92, 326-337. [CrossRef] [PubMed]

275. Gervasi, T.; Lo Curto, R.; Minniti, E.; Narbad, A.; Mayer, M.J. Application of Lactobacillus johnsonii expressing phage endolysin for control of Clostridium perfringens. Lett. Appl. Microbiol. 2014, 59, 355-361. [CrossRef] [PubMed]

276. Wernicki, A.; Nowaczek, A.; Urban-Chmiel, R. Bacteriophage therapy to combat bacterial infections in poultry. Virol. J. 2017, 14, 179. [CrossRef]

277. Zhang, H.; Bao, H.; Billington, C.; Hudson, J.A.; Wang, R. Isolation and lytic activity of the Listeria bacteriophage endolysin LysZ5 against Listeria monocytogenes in soya milk. Food Microbiol. 2012, 31, 133-136. [CrossRef]

278. Van Nassau, T.J.; Lenz, C.A.; Scherzinger, A.S.; Vogel, R.F. Combination of endolysins and high pressure to inactivate Listeria monocytogenes. Food Microbiol. 2017, 68, 81-88. [CrossRef]

279. Chang, Y.; Kim, M.; Ryu, S. Characterization of a novel endolysin LysSA11 and its utility as a potent biocontrol agent against Staphylococcus aureus on food and utensils. Food Microbiol. 2017, 68, 112-120. [CrossRef]

280. Villa, T.G.; Feijoo-Siota, L.; Rama, J.L.R.; Sánchez-Pérez, A.; de Miguel-Bouzas, T. Chapter 40-Enzybiotics: Application in food packaging. In Antimicrobial Food Packaging; Barros-Velázquez, J., Ed.; Academic Press: San Diego, CA, USA, 2016 ; pp. 491-502.

281. Roach, D.R.; Khatibi, P.A.; Bischoff, K.M.; Hughes, S.R.; Donovan, D.M. Bacteriophage-encoded lytic enzymes control growth of contaminating Lactobacillus found in fuel ethanol fermentations. Biotechnol. Biofuels 2013, 6, 20. [CrossRef]

282. Fernández, L.; Gutiérrez, D.; Rodríguez, A.; García, P. Application of bacteriophages in the agro-food sector: A long way toward approval. Front. Cell. Infect. Microbiol. 2018, 8, 296. [CrossRef]

283. Hausbeck, M.; Bell, J.; Medina-Mora, C.; Podolsky, R.; Fulbright, D. Effect of bactericides on population sizes and spread of Clavibacter michiganensis subsp. michiganensis on tomatoes in the greenhouse and on disease development and crop yield in the field. Phytopathology 2000, 90, 38-44. [CrossRef]

284. De Vries, J.; Harms, K.; Broer, I.; Kriete, G.; Mahn, A.; Düring, K.; Wackernagel, W. The bacteriolytic activity in transgenic potatoes expressing a chimeric T4 lysozyme gene and the effect of T4 lysozyme on soil-and phytopathogenic bacteria. Syst. Appl. Microbiol. 1999, 22, 280-286. [CrossRef]

285. Timbermont, L.; Haesebrouck, F.; Ducatelle, R.; Van Immerseel, F. Necrotic enteritis in broilers: An updated review on the pathogenesis. Avian Pathol. 2011, 40, 341-347. [CrossRef]

286. Junjappa, R.P.; Desai, S.N.; Roy, P.; Narasimhaswamy, N.; Raj, J.R.M.; Durgaiah, M.; Vipra, A.; Bhat, U.R.; Satyanarayana, S.K.; Shankara, N. Efficacy of anti-staphylococcal protein P128 for the treatment of canine pyoderma: Potential applications. Vet. Res. Commun. 2013, 37, 217-228. [CrossRef]

287. Angelopoulou, A.; Warda, A.K.; Hill, C.; Ross, R.P. Non-antibiotic microbial solutions for bovine mastitis-live biotherapeutics, bacteriophage, and phage lysins. Crit. Rev. Microbiol. 2019, 45, 564-580. [CrossRef]

288. Donovan, D.M.; Lardeo, M.; Foster-Frey, J. Lysis of staphylococcal mastitis pathogens by bacteriophage phi11 endolysin. FEMS Microbiol. Lett. 2006, 265, 133-139. [CrossRef]

289. Fan, J.; Zeng, Z.; Mai, K.; Yang, Y.; Feng, J.; Bai, Y.; Sun, B.; Xie, Q.; Tong, Y.; Ma, J. Preliminary treatment of bovine mastitis caused by Staphylococcus aureus, with trx-SA1, recombinant endolysin of S. aureus bacteriophage IME-SA1. Vet. Microbiol. 2016, 191, 65-71. [CrossRef]

290. Zduńczyk, S.; Janowski, T. Bacteriophages and associated endolysins in therapy and prevention of mastitis and metritis in cows: Current knowledge. Anim. Reprod. Sci. 2020, 218, 106504. [CrossRef]

291. Vander Elst, N.; Meyer, E. Potential therapeutic application of bacteriophages and phage-derived endolysins as alternative treatment of bovine mastitis. Vlaams Diergeneeskd. Tijdschr. 2018, 87, 181-187. [CrossRef]

292. Wang, Y.; Sun, J.; Lu, C. Purified recombinant phage lysin LySMP: An extensive spectrum of lytic activity for swine streptococci. Curr. Microbiol. 2009, 58, 609-615. [CrossRef] 
293. Hoopes, J.T.; Stark, C.J.; Kim, H.A.; Sussman, D.J.; Donovan, D.M.; Nelson, D.C. Use of a bacteriophage lysin, PlyC, as an enzyme disinfectant against Streptococcus equi. Appl. Environ. Microbiol. 2009, 75, 1388-1394. [CrossRef] [PubMed]

294. Schuch, R.; Nelson, D.; Fischetti, V.A. A bacteriolytic agent that detects and kills Bacillus anthracis. Nature 2002, 418, 884-889. [CrossRef] [PubMed]

295. Sundarrajan, S.; Raghupatil, J.; Vipra, A.; Narasimhaswamy, N.; Saravanan, S.; Appaiah, C.; Poonacha, N.; Desai, S.; Nair, S.; Bhatt, R.N. Bacteriophage-derived CHAP domain protein, P128, kills Staphylococcus cells by cleaving interpeptide cross-bridge of peptidoglycan. Microbiology 2014, 160, 2157-2169. [CrossRef] [PubMed]

296. Ragland, S.A.; Humbert, M.V.; Christodoulides, M.; Criss, A.K. Neisseria gonorrhoeae employs two protein inhibitors to evade killing by human lysozyme. PLoS Pathog. 2018, 14, e1007080. [CrossRef] [PubMed]

297. Davis, K.M.; Akinbi, H.T.; Standish, A.J.; Weiser, J.N. Resistance to mucosal lysozyme compensates for the fitness deficit of peptidoglycan modifications by Streptococcus Pneumoniae. PLoS Pathog. 2008, 4, e1000241. [CrossRef] [PubMed]

298. Vollmer, W. Structural variation in the glycan strands of bacterial peptidoglycan. FEMS Microbiol. Rev. 2008, 32, 287-306. [CrossRef]

299. Guariglia-Oropeza, V.; Helmann, J.D. Bacillus subtilis $\sigma \mathrm{V}$ confers lysozyme resistance by activation of two cell wall modification pathways, peptidoglycan O-acetylation and D-alanylation of teichoic acids. J. Bacteriol. 2011, 193, 6223-6232. [CrossRef]

300. Gründling, A.; Missiakas, D.M.; Schneewind, O. Staphylococcus aureus mutants with increased lysostaphin resistance. J. Bacteriol. 2006, 188, 6286-6297. [CrossRef]

301. DeHart, H.P.; Heath, H.E.; Heath, L.S.; LeBlanc, P.A.; Sloan, G.L. The lysostaphin endopeptidase resistance gene (epr) specifies modification of peptidoglycan cross bridges in Staphylococcus simulans and Staphylococcus aureus. Appl. Environ. Microbiol. 1995, 61, 1475-1479. [CrossRef]

302. Davis, K.M.; Weiser, J.N. Modifications to the peptidoglycan backbone help bacteria to establish infection. Infect. Immun. 2011, 79, 562-570. [CrossRef]

303. Lukacik, P.; Barnard, T.J.; Keller, P.W.; Chaturvedi, K.S.; Seddiki, N.; Fairman, J.W.; Noinaj, N.; Kirby, T.L.; Henderson, J.P.; Steven, A.C. Structural engineering of a phage lysin that targets Gram-negative pathogens. Proc. Natl. Acad. Sci. USA 2012, 109, 9857-9862. [CrossRef]

304. Gutiérrez, D.; Briers, Y. Lysins breaking down the walls of gram-negative bacteria, no longer a no-go. Curr. Opin. Biotechnol. 2021, 68, 15-22. [CrossRef]

305. Briers, Y.; Miller, S.; Lavigne, R. Artilysins Are a Novel Class of Enzyme-Based Antibacterials That Quickly Kill (MultidrugResistant) Pseudomonas Aeruginosa and Their Persisters: From Concept to Application. Available online: https: //www.semanticscholar.org/paper/Artilysins-are-a-novel-class-of-enzyme-based-that-Briers-Miller/bcd3a549fa7c897 ef05fdc1012387b73c4e14f19 (accessed on 2 December 2021).

306. Antonova, N.P.; Vasina, D.V.; Lendel, A.M.; Usachev, E.V.; Makarov, V.V.; Gintsburg, A.L.; Tkachuk, A.P.; Gushchin, V.A. Broad bactericidal activity of the Myoviridae bacteriophage lysins LysAm24, LysECD7, and LysSi3 against Gram-negative ESKAPE pathogens. Viruses 2019, 11, 284. [CrossRef]

307. Díez-Martínez, R.; de Paz, H.; Bustamante, N.; García, E.; Menéndez, M.; García, P. Improving the lethal effect of Cpl-7, a pneumococcal phage lysozyme with broad bactericidal activity, by inverting the net charge of its cell wall-binding module. Antimicrob. Agents Chemother. 2013, 57, 5355-5365. [CrossRef]

308. Ciepluch, K.; Skrzyniarz, K.; Barrios-Gumiel, A.; Quintana, S.; Sánchez-Nieves, J.; de la Mata, F.J.; Maciejewska, B.; Drulis-Kawa, Z.; Arabski, M. Dendronized silver nanoparticles as bacterial membrane permeabilizers and their interactions with P. aeruginosa lipopolysaccharides, lysozymes, and phage-derived endolysins. Front. Microbiol. 2019, 10, 2771. [CrossRef]

309. Gerstmans, H.; Grimon, D.; Gutiérrez, D.; Lood, C.; Rodríguez, A.; van Noort, V.; Lammertyn, J.; Lavigne, R.; Briers, Y. A VersaTile-driven platform for rapid hit-to-lead development of engineered lysins. Sci. Adv. 2020, 6, eaaz1136. [CrossRef]

310. Briers, Y. Phage lysins as simple as Lego. Caspid Tail 2020, 79.

311. De Maesschalck, V.; Gutiérrez, D.; Paeshuyse, J.; Lavigne, R.; Briers, Y. Advanced engineering of third-generation lysins and formulation strategies for clinical applications. Crit. Rev. Microbiol. 2020, 46, 548-564. [CrossRef]

312. Gutierrez Fernandez, D.; Briers, Y. Developments and opportunities of bacteriophage lytic proteins for therapeutics against gram-negative pathogens. In Bacterial Viruses: Exploitation for Biocontrol and Therapeutics; Caister Academic Press: Norwich, UK, 2020; pp. 537-586.

313. Ghose, C.; Euler, C.W. Gram-negative bacterial lysins. Antibiotics 2020, 9, 74. [CrossRef]

314. Yuan, Y.; Li, X.; Wang, L.; Li, G.; Cong, C.; Li, R.; Cui, H.; Murtaza, B.; Xu, Y. The endolysin of the Acinetobacter baumannii phage vB_AbaP_D2 shows broad antibacterial activity. Microb. Biotechnol. 2021, 14, 403-418. [CrossRef]

315. Wang, F.; Ji, X.; Li, Q.; Zhang, G.; Peng, J.; Hai, J.; Zhang, Y.; Ci, B.; Li, H.; Xiong, Y. TSPphg Lysin from the extremophilic thermus bacteriophage TSP4 as a potential antimicrobial agent against both gram-negative and gram-positive pathogenic bacteria. Viruses 2020, 12, 192. [CrossRef]

316. Antonova, N.P.; Vasina, D.V.; Rubalsky, E.O.; Fursov, M.V.; Savinova, A.S.; Grigoriev, I.V.; Usachev, E.V.; Shevlyagina, N.V.; Zhukhovitsky, V.G.; Balabanyan, V.U. Modulation of endolysin LysECD7 bactericidal activity by different peptide tag fusion. Biomolecules 2020, 10, 440. [CrossRef]

317. Oliveira, H.; Melo, L.D.; Santos, S.B.; Nóbrega, F.L.; Ferreira, E.C.; Cerca, N.; Azeredo, J.; Kluskens, L.D. Molecular aspects and comparative genomics of bacteriophage endolysins. J. Virol. 2013, 87, 4558-4570. [CrossRef] 
318. Walmagh, M.; Briers, Y.; Dos Santos, S.B.; Azeredo, J.; Lavigne, R. Characterization of modular bacteriophage endolysins from Myoviridae phages OBP, 201ф2-1 and PVP-SE1. PLoS ONE 2012, 7, e36991. [CrossRef] [PubMed]

319. Loessner, M.J.; Wendlinger, G.; Scherer, S. Heterogeneous endolysins in Listeria monocytogenes bacteriophages: A new class of enzymes and evidence for conserved holin genes within the siphoviral lysis cassettes. Mol. Microbiol. 1995, 16, $1231-1241$. [CrossRef] [PubMed]

320. Payne, K.M.; Hatfull, G.F. Mycobacteriophage endolysins: Diverse and modular enzymes with multiple catalytic activities. PLoS ONE 2012, 7, e34052. [CrossRef] [PubMed]

321. Borysowski, J.; Weber-Dąbrowska, B.; Górski, A. Bacteriophage endolysins as a novel class of antibacterial agents. Exp. Biol. Med. 2006, 231, 366-377. [CrossRef] [PubMed]

322. Jarábková, V.; Tišáková, L.; Godány, A. Phage endolysin: A way to understand a binding function of C-terminal domains a mini review. Nova Biotechnol. Chim. 2015, 14, 117-134. [CrossRef]

323. Fenton, M.; McAuliffe, O.; O’Mahony, J.; Coffey, A. Recombinant bacteriophage lysins as antibacterials. Bioeng. Bugs 2010, 1, 9-16. [CrossRef]

324. Briers, Y.; Lavigne, R.; Volckaert, G.; Hertveldt, K. A standardized approach for accurate quantification of murein hydrolase activity in high-throughput assays. J. Biochem. Biophys. Methods 2007, 70, 531-533. [CrossRef]

325. Fowler, V.G., Jr.; Das, A.F.; Lipka-Diamond, J.; Schuch, R.; Pomerantz, R.; Jáuregui-Peredo, L.; Bressler, A.; Evans, D.; Moran, G.J.; Rupp, M.E.; et al. Exebacase for patients with Staphylococcus aureus bloodstream infection and endocarditis. J. Clin. Investig. 2020, 130, 3750-3760. [CrossRef]

326. Paul, V.D.; Rajagopalan, S.S.; Sundarrajan, S.; George, S.E.; Asrani, J.Y.; Pillai, R.; Chikkamadaiah, R.; Durgaiah, M.; Sriram, B.; Padmanabhan, S. A novel bacteriophage Tail-Associated Muralytic Enzyme (TAME) from Phage K and its development into a potent antistaphylococcal protein. BMC Microbiol. 2011, 11, 226. [CrossRef]

327. Saravanan, S.R.; Paul, V.D.; George, S.; Sundarrajan, S.; Kumar, N.; Hebbur, M.; Kumar, N.; Veena, A.; Maheshwari, U.; Appaiah, C.B. Properties and mutation studies of a bacteriophage-derived chimeric recombinant staphylolytic protein P128: Comparison to recombinant lysostaphin. Bacteriophage 2013, 3, e26564. [CrossRef]

328. Nair, S.; Poonacha, N.; Desai, S.; Hiremath, D.; Tuppad, D.; Mohan, T.; Chikkamadaiah, R.; Durgaiah, M.; Kumar, S.; Channabasappa, S. Restoration of sensitivity of a diverse set of drug-resistant Staphylococcus clinical strains by bactericidal protein P128. J. Med. Microbiol. 2018, 67, 296-307. [CrossRef]

329. Nair, S.; Desai, S.; Poonacha, N.; Vipra, A.; Sharma, U. Antibiofilm activity and synergistic inhibition of Staphylococcus aureus biofilms by bactericidal protein P128 in combination with antibiotics. Antimicrob. Agents Chemother. 2016, 60, 7280-7289. [CrossRef]

330. Poonacha, N.; Nair, S.; Desai, S.; Tuppad, D.; Hiremath, D.; Mohan, T.; Vipra, A.; Sharma, U. Efficient killing of planktonic and biofilm-embedded coagulase-negative staphylococci by bactericidal protein P128. Antimicrob. Agents Chemother. 2017, 61, e00457-17. [CrossRef]

331. Vipra, A.A.; Desai, S.N.; Roy, P.; Patil, R.; Raj, J.M.; Narasimhaswamy, N.; Paul, V.D.; Chikkamadaiah, R.; Sriram, B. Antistaphylococcal activity of bacteriophage derived chimeric protein P128. BMC Microbiol. 2012, 12, 41. [CrossRef]

332. Drilling, A.J.; Cooksley, C.; Chan, C.; Wormald, P.J.; Vreugde, S. Fighting sinus-derived Staphylococcus aureus biofilms in vitro with a bacteriophage-derived muralytic enzyme. Int. Forum Allergy Rhinol. 2016, 6, 349-355. [CrossRef]

333. George, S.E.; Chikkamadaiah, R.; Durgaiah, M.; Joshi, A.A.; Thankappan, U.P.; Madhusudhana, S.N.; Sriram, B. Biochemical characterization and evaluation of cytotoxicity of antistaphylococcal chimeric protein P128. BMC Res. Notes 2012, 5, 280. [CrossRef]

334. Climo, M.W.; Ehlert, K.; Archer, G.L. Mechanism and suppression of lysostaphin resistance in oxacillin-resistant Staphylococcus aureus. Antimicrob. Agents Chemother. 2001, 45, 1431-1437. [CrossRef]

335. Sriram, B.; Chikkamadaiah, S.; Durgaiah, M.; Hariharan, S.; Jayaraman, R.; Kumar, S.; Maheshwari, U.; Nandish, P. Pharmacokinetics and efficacy of ectolysin P128 in a mouse model of systemic Methicillin Resistant Staphylococcus aureus (MRSA) infection. In Proceedings of the ASM Microbe, New Orleans, LA, USA, 1-5 June 2017.

336. Channabasappa, S.; Chikkamadaiah, R.; Durgaiah, M.; Kumar, S.; Ramesh, K.; Sreekanthan, A.; Sriram, B. Efficacy of chimeric ectolysin P128 in drug-resistant Staphylococcus aureus bacteraemia in mice. J. Antimicrob. Chemother. 2018, 73, 3398-3404. [CrossRef]

337. Channabasappa, S.; Durgaiah, M.; Chikkamadaiah, R.; Kumar, S.; Joshi, A.; Sriram, B. Efficacy of novel antistaphylococcal ectolysin P128 in a rat model of methicillin-resistant Staphylococcus aureus bacteremia. Antimicrob. Agents Chemother. 2018, 62, e01358-17. [CrossRef]

338. Son, J.; Kim, E.B.; Lee, S.; Jun, S.; Yoon, S.-J.; Kang, S.; Choi, Y. Characterization of Staphylococcus aureus derived from bovine mastitis and isolation of two lytic bacteriophages. J. Gen. Appl. Microbiol. 2010, 56, 347-353. [CrossRef]

339. Jun, S.Y.; Jung, G.M.; Son, J.-S.; Yoon, S.J.; Choi, Y.-J.; Kang, S.H. Comparison of the Antibacterial Properties of Phage Endolysins SAL-1 and LysK. Antimicrob. Agents Chemother. 2011, 55, 1764-1767. [CrossRef]

340. Schuch, R.; Lee, H.M.; Schneider, B.C.; Sauve, K.L.; Law, C.; Khan, B.K.; Rotolo, J.A.; Horiuchi, Y.; Couto, D.E.; Raz, A. Combination therapy with lysin CF-301 and antibiotic is superior to antibiotic alone for treating methicillin-resistant Staphylococcus aureusinduced murine bacteremia. J. Infect. Dis. 2014, 209, 1469-1478. [CrossRef]

341. Schuch, R.; Khan, B.K.; Raz, A.; Rotolo, J.A.; Wittekind, M. Bacteriophage lysin CF-301, a potent antistaphylococcal biofilm agent. Antimicrob. Agents Chemother. 2017, 61, e02666-16. [CrossRef] 
342. Sauve, K.; Jandourek, A.; Cassino, C.; Schuch, R. Lysin CF-301 demonstrates in vitro synergy with conventional antibiotics against Staphylococcus aureus. In Open Forum Infectious Diseases; Oxford University Press: Oxford, UK, 2017; p. 370.

343. Oh, J.T.; Cassino, C.; Schuch, R. Postantibiotic and sub-MIC effects of exebacase (lysin CF-301) enhance antimicrobial activity against Staphylococcus aureus. Antimicrob. Agents Chemother. 2019, 63, e02616-18. [CrossRef]

344. Indiani, C.; Sauve, K.; Raz, A.; Abdelhady, W.; Xiong, Y.Q.; Cassino, C.; Bayer, A.S.; Schuch, R. The antistaphylococcal lysin, CF-301, activates key host factors in human blood to potentiate methicillin-resistant Staphylococcus aureus bacteriolysis. Antimicrob. Agents Chemother. 2019, 63, e02291-18. [CrossRef]

345. Asempa, T.E.; Abdelraouf, K.; Carabeo, T.; Schuch, R.; Nicolau, D.P. Synergistic activity of exebacase (CF-301) in addition to daptomycin against Staphylococcus aureus in a neutropenic murine thigh infection model. Antimicrob. Agents Chemother. 2019, 64, e02176-19. [CrossRef]

346. Anastasiou, D.; Jandourek, A.; Traczewski, M.; Cassino, C.; Schuch, R. 1342. Comparison of lysin CF-301 (Exebacase) activity against S. aureus isolates. In Open Forum Infectious Diseases; Oxford University Press: Oxford, UK, 2018; p. 410.

347. Anastasiou, D.; Cassino, C.; Schuch, R. 711. Exebacase (Lysin CF-301) activity against Staphylococcus aureus (S. aureus) isolates from bacteremic patients enrolled in a phase 2 study (CF-301-102). In Open Forum Infectious Diseases; Oxford University Press: Oxford, UK, 2019.

348. Hendricks, A.J.; Mills, B.W.; Shi, V.Y. Skin bacterial transplant in atopic dermatitis: Knowns, unknowns and emerging trends. J. Dermatol. Sci. 2019, 95, 56-61. [CrossRef]

349. Herpers, B.; Badoux, P.; Pietersma, F.; Eichenseher, F.; Loessner, M. Specific lysis of methicillin susceptible and resistant Staphylococcus aureus by the endolysin Staphefekt SA. 100 TM. In Proceedings of the 24th European Congress of Clinical Microbiology and Infectious Diseases (ECCMID), Barcelona, Spain, 10-13 May 2014.

350. Totté, J.; de Wit, J.; Pardo, L.; Schuren, F.; van Doorn, M.; Pasmans, S. Targeted anti-staphylococcal therapy with endolysins in atopic dermatitis and the effect on steroid use, disease severity and the microbiome: Study protocol for a randomized controlled trial (MAAS trial). Trials 2017, 18, 404. [CrossRef] [PubMed]

351. Fischetti, V.A. Lysin therapy for Staphylococcus aureus and other bacterial pathogens. In Staphylococcus aureus; Springer: Cham, Switzerland, 2015; pp. 529-540.

352. Lysando. Available online: www.lysando.com (accessed on 2 December 2021).

353. Zipfel, C.; Robatzek, S. Pathogen-associated molecular pattern-triggered immunity: Veni, vidi ... ? Plant Physiol. 2010, 154, 551-554. [CrossRef] [PubMed]

354. Bruno, B.J.; Miller, G.D.; Lim, C.S. Basics and recent advances in peptide and protein drug delivery. Ther. Deliv. 2013, 4, 1443-1467. [CrossRef] [PubMed]

355. Agu, R.U.; Ugwoke, M.I.; Armand, M.; Kinget, R.; Verbeke, N. The lung as a route for systemic delivery of therapeutic proteins and peptides. Respir. Res. 2001, 2, 1-12.

356. Portilla, S.; Fernández, L.; Gutiérrez, D.; Rodríguez, A.; García, P. Encapsulation of the antistaphylococcal endolysin LysRODI in pH-sensitive liposomes. Antibiotics 2020, 9, 242. [CrossRef]

357. Hathaway, H.; Ajuebor, J.; Stephens, L.; Coffey, A.; Potter, U.; Sutton, J.M.; Jenkins, A.T.A. Thermally triggered release of the bacteriophage endolysin CHAPK and the bacteriocin lysostaphin for the control of methicillin resistant Staphylococcus aureus (MRSA). J. Control. Release 2017, 245, 108-115. [CrossRef]

358. Heselpoth, R.D.; Euler, C.W.; Schuch, R.; Fischetti, V.A. Lysocins: Bioengineered antimicrobials that deliver lysins across the outer membrane of Gram-negative bacteria. Antimicrob. Agents Chemother. 2019, 63, e00342-19. [CrossRef]

359. Ozsoy, Y.; Gungor, S.; Cevher, E. Nasal delivery of high molecular weight drugs. Molecules 2009, 14, 3754-3779. [CrossRef] 